\title{
The Changing Plea Bargaining Debate
}

\author{
Albert W. Alschuler†
}

This Article examines plea bargaining both as a sentencing device and as a form of dispute resolution. Defenses of plea bargaining a decade or so ago usually einphasized its sentencing function, arguing that guilty defendants who acknowledged their guilt inerited lighter sentences than comparable defendants who insisted upon standing trial. Most current defenses start from a different vantage point and treat plea bargaming primarily as a form of dispute resolution. They suggest that it is desirable to afford both the defendant and the state the option of coinpromising factual and legal disputes and that the consent of the affected parties can justify "intermediate" dispositions by which both sides avoid the risks of hitigation. This Article contends that neither justification is persuasive and that plea bargaining remains an inherently unfair and irrational process, one that turns inajor treatinent consequences upon a single tactical decision irrelevant to any proper objective of criminal proceedings. Although most of iny earlier writing on plea bargaming viewed this subject from an operational perspective, this Article adopts, here and there, a broader, inore jurisprudential viewpoint.

I

\section{Plea Bargaining as a Sentencing Device}

\section{A. Of Rewards, Penalties and Sentencing Policy: Some Preliminary Observations}

Criminal defendants today plead guilty in overwhelming numbers prinarily because they perceive that this action is likely to lead to inore leirient treatment than would follow conviction at trial. ${ }^{1}$ A number of

$\dagger$ Professor of Law, University of Colorado. A.B. 1962, Harvard University; LL.B. 1965, Harvard University.

The preparation of this Article was supported by Grant No. 79-NI-AX-0101 of the National Institute of Justice, and I am grateful to the staff of the Institute-especially to my project monitor, Linda James McKay-for encouragement and guidance. I am also grateful to Richard A. Posner, Stephen F. Williams, Peter Tillers, and Carol F. Lee for valuable suggestions. Of course the opimions and conclusions expressed in this Article are simply my own.

1. It is commonly estimated that $90 \%$ of all criminal convictions are the result of guilty pleas. D. Newman, Conviction: The Determination of Guilt or InNocence Without TRIAL 3 (1966). Justice Henry T. Lummus once observed, "When defendants plead guilty they 
studies suggest that this perception is justified. ${ }^{2}$ Professor Beverly Blair Cook found, for example, that violators of the Federal Selective Service Act who were convicted at jury trials received sentences about twice as severe as offenders who pleaded guilty, ${ }^{3}$ and statistics compiled by the Administrative Office of the United States Courts indicate that the "sentence differential" between guilty-plea and trial defendants may be even more substantial in other offense categories. ${ }^{4}$ Sonie enipirical studies have concluded that a federal defendant's choice of guilty plea, bench trial, or jury trial is likely to have a greater impact on his sentence than even his prior criminal record. ${ }^{5}$ In addition, Professor Hans Zeisel found that the sentences of New York City defendants convicted at trial were $136 \%$ more severe than those proposed by prosecutors in pretrial offers to the same defendants. ${ }^{6}$ In a textual footnote, this Article examines the limitations of three recent studies that, so far as I am aware, are the only ones that may call the existence of a sentence differ-

expect more leniency than when convicted by a jury, and must receive it, or there will be no such pleas." H. Lummus, ThE TRIAL JUDge 46 (1937).

2. See, e.g., M. Zalman, C. Ostrom, P. Guillams \& G. Peaslee, Sentencing in Michigan: Report of the Michigan Felony Sentencing Project 268 (1979) (after controlling for other variables, "it seems quite clear that asking for a trial tends to increse the probabihty of being incarcerated-oftentimes quite substantially"); Shin, Do Lesser Pleas Pay?: Accommodations in the Sentencing and Parole Processes, 1 J. CRIM. JusT. 27, 31 (1973) (mean sentence for offenders charged with robbery and felonious assault 3.2 years in guilty-plea cases and 6.0 years in trial cases); Zimring, Eigen \& O'Malley, Punishing Homicide in Philadelphia: Perspectives on the Death Penalty, 43 U. CHI. L. REv. 227 (1976) (30\% of the homicide defendants convicted at trial but no homicide defendants who pleaded guilty were sentenced to life imprisonment or death; a guilty plea typically led to incarceration for only two years); Oster \& Simon, Jury Trial a Sure Way to Increase the Rap, Chicago Sun Times, Sept. 17, 1973, at 4 (82\% of the convicted murder defendants who exercised the right to jury trial received sentences of 30 years or more while no murder defendants who pleaded guilty received sentences of 30 years or more); J. Rink, Bargaining im Criminal Cases: A Test of the Apphicability of a Pohtical Exchange Model, app. Table 5 (1975) (unpublished master's thesis, Department of Political Science, University of Wisconsin, Milwaukee) (imprisonment twice as likely for defendants convicted at trial as for defendants who pleaded guilty).

3. Cook, Sentencing Behavior of Federal Judges: Drafi Cases 1972, 42 U. CIN. L. Rev. 597, 609 (Table 3) (1973).

4. See Administrative Office of the United States Courts, Federal Offenders IN THE UNited States District Courts 13 (Exhibit VII), 15 (Exhibit VIII), 55 (Table 15) (1971).

5. See L. Sutton, Federal Sentencing Patterns: A Study of Geographial VariaTrons 17-19 (1978); Tiffany, Avichai \& Peters, A Statistical Analysis of Sentencing in Federal Court: Defendants Convicted After Trial, 1967-68, 4 J. LEGAL STUD. 369, 380 (1975).

6. Zeisel, The Offer That Cannot Be Refused, in F. ZimRIng \& R. FRASE, The Criminal

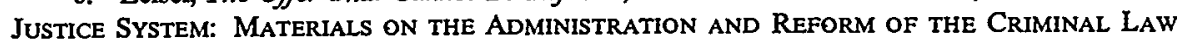
558,561 (1980). Variations in cases and defendants certainly cannot explain a disparity between preplea offers and post-trial sentences when exactly the same cases and the same defendants are the subject of both inquiries. Nevertheless, the plea bargaining process in New York City was so successful at the time of Zeisel's imvestigation that his sample was sinall. Although Zeisel began with 369 cases, he found only eight in which a direct comparison of preplea offers and post-trial sentences could be niade. 
7. In the first of these studies, James Eisenstein and Herbert Jacob examined the cases of 4,500 felony defendants in Baltimore, Detroit, and Chicago. Although they reported that a simple "cross-tabulation of sentence with disposition mode" indicated "that jury trials cominand a penalty of sentences which are three or four times longer than bench trial or guilty plea," they concluded that this apparent difference could be explained almost entirely by factors other than the defendants' pre-conviction decisions concerning plea and mode of trial. J. EISENSTEIN \& H. JACOB, Felony Justice: An ORganizational Perspective 270-82 (1977). I have elsewhere sketched soune doubts about the Eisenstein-Jacob inethodology. See Alschuler, The Trial Judge's Role in Plea Bargaining (pt. D, 76 CoLuM. L. REv. 1059, 1086-87 \& n.89 (1976). Yet more significant than these doubts of a lawyer not tramed in statistics is the fact that Professor Peter F. Nardulli analyzed the same Chicago cases as Eisenstein and Jacob and reached the opposite conclusion. Although Eisenstein and Jacob excluded from their analysis all cases in which probated sentences were awarded, Nardulli included these cases. He reported dramatic sentence differentials that could not be explained by case or defendant characteristics. P. NARDULL, THE CoURTroom Elite: An Organizational Perspective on Criminal Justice 218 (1978).

A study of case disposition patterns in "Metro City" by Thomas M. Uhlman and N. Darlene Walker reported a very large sentence differential between jury trial and bench trial convictions but almost no sentence differential between bench trial and guilty-plea convictions. Uhlman \& Walker, A Plea Is No Bargain: The Impact of Case Disposition on Sentencing, 60 Soc. Sc1. Q. 218 (1979). See also Uhlman \& Walker, "He Takes Some of My Time; I Take Some of His": An Analysis of Judicial Sentencing Patterns in Jury Cases, 14 LAw \& Soc'y REv. 323 (1980). Nevertheless, the import of these findings may be somewhat different from that suggested by the authors. Although the jurisdiction that Uhlman and Walker studied was not identified, it was apparently Philadelphia, which has been characterized by a very low rate of guilty pleas. (Philadelphia's distinctive criminal justice system is described in Appendix A infra.) Far from indicating a sentencing pattern that is typical of American jurisdictions, the Uhlman-Walker study seeined to indicate a divergent pattern that could enable most of these jurisdictions to reduce their reliance on plea bargaining substantially. Although the authors did mention Metro City's low guilty plea rate and its extensive use of bencli trials, they did not consider this possibihity. They viewed their data instead as supporting the Eisenstein-Jacob thesis.

The title of an influential paper by Williain M. Rhodes posed a question: W. Rhodes, Plea Bargaining: Who Gains? Who Loses? (1978) (part of the PROMIS Research Project of the Institute of Law and Social Research). The paper's answer was emphatically that defendants were the losers. Rhodes analyzed disposition patterns for four types of offenses in the District of Columbia, and then, using numerous characteristics of the cases that had ended in guilty pleas, he cstimated how these cases would have been resolved lad the defendants exercised the right to trial. "[I]t appears," he concluded, "that defendants who enter guilty pleas (a) frequently forego a reasonably good chance of acquittal at trial but (b) do not always receive demonstrable sentence concessions froin the prosecutor or the judge in return." Id. at 20.

Although Rhodes' study sometimes has been interpreted as casting doubt upon the existence of any sentence differential whatever, several caveats to this conclusion, inost of them noted by the author himself, inerit einphasis. First, in the most serious offense category that Rhodes studied, the sentence differential did seein dramatic:

Using the regression equations, we predicted that 24 percent of those defendants who entered a guilty plea after being arrested for robbery would receive probation. In fact, 43 percent received probation. We also predicted that 32 percent of the robbery offenders would receive a prison sentence with a minimum length of three years or more. In fact, only 14 percent received such a severe sentence following a guilty plea. This is evidence that considerable bargaining is occurring for robbery cases and that, in general, a suspect can expect to fare better if he enters a guilty plea instead of being convicted at trial. Id. at 43 .

Second, even in the remaining three offense categories that Rhodes studied, there were some indications of a sentence differential-a small number of defendants in each category, for example, who apparently had obtained probated sentences only by virtue of their pleas of guilty:

For assault, 77 percent of the defendants were expected to receive probation; 80 percent 


\section{though the empirical evidence is not of one piece, the best conclusion}

actually received probation. For larceny, 67 percent were predicted to be placed on probation; 70 percent actually were. For burglary, we expected 51 percent of the defendants to receive probation; 53 percent did in fact. Based on these data, we conclude that prosecutors are not giving significant plea bargaining concessions and that judges are not rewarding guilty pleas with sentence leniency for these three offenses.

Id.

Third, as Rhodes' study described sentencing practices in the District of Columbia, that jurisdiction seemed atypical. As this Article has noted, virtually all examinations of sentencing patterns in other places have found at least an initial, apparent disparity between the sentences imposed following pleas of guilty and those imposed following convictions at trial. Rhodes' inethodology, however, did not "explain" a sentence differential that a less sophisticated inspection of post-guilty-plea and post-trial sentences might have suggested. To the contrary, in the offense categories in which Rhodes doubted that defendants were rewarded for their guilty pleas, a simple inspection of post-plea and post-trial results would have suggested an even smaller disparity. See id. at 42 \& Table 2.

In judging whether the jurisdiction that Rhodes studied was typical, it is noteworthy that Rhodes and a coauthor recently prepared a study of sentencing practices in eight federal district courts. W. Rhodes \& C. Conly, Federal Sentencing Guidelines: Will They Shift Sentencing Discretion From Judges to Prosecutors? (unpublished paper presented at the Annual Meeting of the American Sociological Association, Aug. 27-31, 1980). This study reported that prosecutorial plea bargaining "has a sizeable impact on the seriousness of the offense with which the offender is convicted." Id. at 14. It also reported that, far fron offetting prosecutorial charge concessions, judges granted further concessions to guilty-plea defendants in the sentencing process. Id. at 2829. The study found significant sentence differentials in four out of five offense categories even with other variables controlled and even when the comparison focused on the offense of conviction rather than the offense originally charged. Id. at 22 .

Fourth, a substantial majority of defendants in the offense categories in which the sentence differential seemed minor were sentenced to probation whether they were convicted by guilty plea or by trial. W. Rhodes, supra, at 49 . Because probation was the least severe of the sentencing classifications that Rhodes employed and because relatively minor concessions regarding the length and conditions of probation were unexamined, it was obviously impossible for a majority of the guilty-plea defendants in Rhodes' sample to "do better" in sentencing than a majority of the defendants convicted at trial. Under Rhodes' scheme, it would have been improving on perfection for them to do so.

Moreover, Rhodes reported that when jail sentences were imposed following convictions at trial in these offense categories, the sentences were likely to be short. Id. When the stakes are low, many defendants may indeed plead guilty without receiving significant sentencing concessions in return. In "low sanction" situations, the "process costs" involved in standing trial一the loss of time and wages required by court appearances, the expense for many defendants of hiring attorneys, the costs of posting bond or of hiring bondsinen, the energy involved in locating and rounding up witnesses and the like-assume substantial inportance. The minimization of these process costs can lead rational, self-interested defendants to plead gnilty even when they realize that they will receive no reward for this act in sentencing. See M. Fefley, The Process Is the PunishMENT (1979).

In "high sanction" situations, however, process costs are relatively unimportant. Few defendants seem likely to regard the loss of a few days at trial or even the payment of substantial attorneys' fees as a significant deterrent to trial when they face potential sentences of several years' imprisonment and believe that exercise of the right to trial may eliminate that risk. In these situations, sentencing concessions seem far more necessary if large numbers of defendants are to be persuaded to forego the right to trial. It is noteworthy that in one of the offense categories in which Rhodes regarded the sentence differential as generally unimportant, a clear differential did appear at the highest sanction level. On the basis of offense and offender characteristics, Rhodes estmuated that $11 \%$ of the defendants who pleaded guilty to burglary would be sentenced to prison terms of more than three years. In fact, only five percent of the guilty-plea defendants received such severe sentences. W. Rhodes, supra, at 42 , Table 2 . For a burglary defendant who had a 


\section{probably is that in a great many cases the sentence differential in America assumes shocking proportions. ${ }^{8}$}

substantial prior record or whose alleged crime reflected serious aggravating circumstances, a better than $50 \%$ reduction in the chance of receiving a long prison sentence surely would have provided a signficant imducement for a plea of guilty. (In the two other offense categories in which the sentence differential seemed minor, the number of defendants for whom sentences of greater than three years were predicted was extremely small. Id.)

Fifth and finally, any empirical study that did in fact report that guilty-plea defendants were treated no differently as a group than defendants convicted at trial would confront most observers of the criminal courts with a seemingly insuperable problem of cognitive dissonance. In Bordenkircher v. Hayes, 434 U.S. 357 (1978), the Supreme Court upheld the constitutionahity of imposing a life sentence upon a trial defendant who had declined a prosecutor's offer to recommend a five-year sentence im exchange for his plea of guilty. Most prosecutors and defense attorneys can recount similarly dramatic instances in which the rejection of suggested bargams ultimately cost defendants years of their lives. See, e.g., text accompanying notes 32-37 infra. It seems doubtful that these cases, even if unusual, would fail to make so much as a ripple in statistical patterns or that they could be offset by an equal number of cases in which defendants who would have received life sentences had they entered bargamed pleas were sentenced only to fiveyear terms following their convictions at trial. Rhodes reported that when he confronted Washington, D.C., prosecutors and judges with his findings, they expressed surprise. One judge declared that the judges of his court tried to "give reductions for pleas" and, indeed, that he did so himself. W. Rhodes, supra, at 49 . It is difficult to beheve that this judge was so imept at the task that he failed.

8. I suspect that the following propositions will provoke little disagreement. Some defendants who plead guilty - a substantial number-do receive approximately the same sentences that they would have received following convictions at trial. When, for exaunple, a flrst-offender has committed a minor crime against property, a short probated sentence is likely to seein alinost inevitable regardless of the method of his conviction. Some of the defendants whose guilty pleas do not produce leniency in sentencing may very well "know the score" and inay submit their pleas for other reasons. This possibility seems strongest when the potential sanctions are low. Other defendants, however, may very well be misled. Although I do not suggest that defense attorneys are the only sources of their misinformation, it is in the interest of these lawyers to convince their clients (and indeed themselves) that they have provided a unique and benefleial service. This interest may lead a lawyer to present-and even to view-a seemingly favorable outcome as the product of his skillful bargaining although the same outcome would have followcd a conviction at trial or an unbargained guilty plea by an unrepresented defendant. Certamly the plea negotiation process lends itself to this misperception on the part of both lawyers and defendants. See Alschuler, The Defense Attorney's Role in Plea Bargaining, 84 YALE L.J. 1179 (1975). Still other defendants whose guilty pleas do not lead to greater leniency than would have followed their convictions at trial may plead guilty simply because they realize that they have little chance of acquittal and sense that trial might produce more severe consequences. If this risk is genuine (in which event it probably should materialize often enough in trial cases to make soine impact on statistical patterns), these defendants should be regarded as receiving "valuable consideration" for their pleas despite the absence of a more tangible reward. Fimally, there are cases in which defendants do receive significantly lighter sentences following their guilty pleas than they would have received following convictious at trial-and some in which the rewards that they obtain are dramatic.

Obviously, then, efforts to measure the sentence differential are atteunts to reduce a complex world of horrors, of lesser imjustices, and of things not at all unjust to a collectivist "bottom line." The inquiry is valuable; indeed, as noted in the text, the evidence seeuns to establish that the sentence differential in America commonly assumes shocking proportions. Nevertheless, the himitations of any statistical imquiry are apparent, and the imjustice that may arise in an individual case cannot be diminished by the fact that it does not arise in others. In evaluating our system of criminal justice, one Bordenkircher $v$. Hayes may be worth a dozen statistical regressions, for even if the regressions were to suggest that the one case was aberational and that nothing else was 
If the commonly perceived sentence differential somehow were shown to be a myth, that circumstance might answer one objection to plea bargaiming at the same time that it suggested another. The absence of any sentence differential would tend to establish that lazy prosecutors were not bargaining away the public interest in securing adequate punishment for offenders, but it would raise the possibility that prosecutors were protecting this public interest only by defrauding defendants of their rights. I have wondered occasionally whether it should be a worse crime to sell herom or to sell talcum powder on the representation that it is heroin; ${ }^{9}$ and if, despite the widespread practice of plea bargaining, few defendants are rewarded for their pleas, the bargaining process would seem to sell them a great deal of talcum powder instead. Although there are undoubtedly cases in which defendants are willing to plead guilty without any expectation of sentencing leniency (cases, for exainple, im which they are remorseful, sense no chance of victory at trial, or seek to avoid the process costs that exercise of the right to trial would imcur), these are cases in which the bargaining process-the offering of apparent concessions-is simply unnecessary. Plea negotiation works im other cases only because defendants have been led to beheve that their bargains are in fact bargains. If this belief is erroneous, it seems likely that the defendants have been deluded into sacrificing their constitutional rights for nothing. ${ }^{10}$ Unless the advocates of plea bargaining contend that defendants sliould be misled, they apparently must defend the proposition that these defendants' pleas should make some difference in their sentences.

Defending plea negotiation as a sentencing policy might seem difficult, however. One inark of a just legal system is that it minimizes the effect of tactical choices upon the outconne of its processes. In criminal cases, the extent of an offender's punishment ought to turn primarily upon what he did and, perhaps, upon his personal characteristics rather than upon a postcrime, postarrest decision to exercise or not to exercise some procedural option. As an initial matter, it seens unjust that when two virtually identical defendants have committed virtually identical

amiss, a system that permitted and condoned even an occasional Bordenkircher would seem to bear a significant burden of justification.

9. In most jurisdictions, of course, the actual sale of herom is by far the more serious crime. See, e.g., Colo. REv. STat. § 12-22-322(2)(c) (1973) (sale of herom a class 2 felony); id. § 18-4$401(2)$ (b), (c) (theft by deception of less than $\$ 200$ a class 2 misdemeanor, and of less than $\$ 10,000$, a class 4 felony).

10. One of the studies that has been viewed as casting doubt on the existence of a sentence differential concluded that "guilty plea defendants appear to have, on the average, about as good a chance of acquittal as defendants who demand a trial." W. Rhodes, supra notc 7 , at 45 . If one believes that large numbers of guilty-plea defendants would have had a substantial chance of acquittal at trial and that they have not been rewarded for their pleas, the inagnitude of the dcception necessary to induce today's level of guilty pleas begins to seem awesome. 
crimes, one should receive a more severe sentence than the other only because he has exercised his right to trial. Quite apart from the threat that plea bargaining may pose to constitutional values, the danger that it may present of convicting innocent defendants, and a variety of other objections to it, plea negotiation may be inherently unfair as a matter of sentencing policy.

Nevertheless, in resisting this conclusion about a decade ago, some prominent advocates of plea bargaining articulated a series of penological rationales for extending special consideration to defendants who plead guilty. These rationales usually were designed to show that, although it is improper to penalize a defendant for exercismg the right to trial, it is appropriate to reward a defendant for pleading guilty. The American Bar Association and the American Law Institute were among the prestigious authorities who endorsed this perceived distinction between rewarding the waiver of a right and penalizimg its exercise. ${ }^{11}$ The Supreme Court, however, recently questioned whether a principled distimction between these two concepts can be drawn. ${ }^{12}$ of course, even defenders of the distinction would concede that it is largely theoretical; it is usually impossible for an observer (other than perhaps the sentencing authority itself) to determine whether a particular defendant has been "penalized" for standing trial or has failed to receive a "reward" for pleading guilty. More seriously, the ABA-ALI

11. ABa Project on Standards for Criminal Justice, Standards Relating to Pleas of Gullty $\S 1.8(\mathrm{~b})$ (1968) [hereinafter cited as 1968 ABA STANDARDS]; ABA STANDARdS Relating to the administration of Criminal Justice, Pleas of Guilty \$ 14.1.8(b) (2d ed. 1979) [hereinafter cited as 1979 ABA Standards]; AL1 Model Code of PrE-ARralonment Procedure § 350.3(3), at 244-45, 609-17 (1975).

Chief Judge Williain Cainpbell once wrote, "[I]t is incorrect, in my opimion, to say . . . that a 'inore severe sentence' is imposed on a defendant who stands trial. Rather, it seeins more correct to ine to say that the defendant who stands trial is sentenced without leniency." United States $v$. Wiley, 184 F. Supp. 679, 685 (N.D. Ill. 1960); accord, United States v. Rainos, 572 F.2d 360, 363 n.2 (2d Cir. 1978) (Lumbard, J., concurring); Fielding v. LeFevre, 548 F.2d 1102, 1106 (2d Cir. 1977); United States v. Rodriguez, 429 F. Supp. 520, 524 n.5 (S.D.N.Y. 1977); Commonwealth v. Staley, 229 Pa. Super. Ct. 322, 324, 324 A.2d 393, 395 (1974); Church, In Defense of "Bargain Justice," 13 LAw \& Soc'y REv. 509, $519-20$ (1979); King, Criminal Procedure from the Viewpoint of the Trial Judge, 25 ConN. B.J. 202, 205 (1951); Nenuerson, Coercive Sentencing, 64 MinN. L. REv. 669, 698-99 (1980); Westen \& Westin, A Constitutional Law of Remedies for Broken Plea Bargains, 66 CALIF. L. REv. 471, 489 (1978).

12. In Roberts v. United States, $100 \mathrm{~S}$. Ct. 1358 (1980), a trial judge inentioned a drug dealer's refusal to name his supphers as one circumstance that the judge had considered in sentencing. The defendant apparently conceded that a sentencing judge properly could reward a defendant's cooperation with the authorities, but he argued that a defendant's failure to volunteer information should not be regarded as justification for enhancing his sentence. The Supreine Court responded:

We doubt that a principled distinction may be drawn between "enhancing" the punishment imposed upon the petitioner and denying him the "leniency" he claims would be appropriate if he had cooperated. The question for decision is simply whcther the petitioner's failure to cooperate is relevant to the currently understood goals of sentencing. Id. at 1363 n.4. 
position raises an epistimological issue. If the concepts of reward and penalty are relative-if these concepts derive their meaning only from each other-the assertion that some defendants are rewarded and none penalized is simply schizophremic. As Judge David L. Bazelon, referring to the implausibility of a system im which there are winners but no losers, once observed, "If we are 'lenient' toward [defendants who plead guilty], we are by precisely the same token 'more severe' toward [those who plead not guilty]." 13

An apparent escape from this conclusion, however, hes in hypothesizing a "proper" sentence for each criminal offender. A "proper" sentence might be defined as one that is adequate to accomplish whatever objectives of the criminal law one accepts as persuasive. In retributive terms, the "proper" sentence is simply the sentence that the offender "deserves"; if one accepts more utilitarian justifications for punishment, it inay be the sentence necessary to acconiphsh deterrent, incapacitative, or rehabilitative goals. Of course, because "undeserved" or "gratuitous" suffering is indefensible on any theory, ${ }^{14}$ the "proper" sentence can be no greater than is necessary to accomplish these social purposes, whatever they may be and however difficult the appropriate balance among them may be to articulate.

If it is possible to envision a "proper" sentence for each offender, at least as an abstract inatter, an increase in this sentence when the offender has exercised his right to trial can be seen as an mappropriate penalty, and a reduction in the sentence when the offender has pleaded guilty can be seen as a reward. ${ }^{15}$ The concept of a "proper" sentence thus gives meaning to the distinction between reward and penalty, ${ }^{16}$

13. Scott v. United States, 419 F.2d 264, 278 (D.C. Cir. 1969) (Bazelon, C.J.); accord, People v. Earegood, 12 Mich. App. 256, 268, 162 N.W.2d 802, 812 (1968), modified, 383 Mich. 82, 173 N.W.2d 205 (1970); L. Weinreb, Denial of Justice: Criminal Process in the United States 85 (1977); Comment, The Infuence of the Defendant's Plea on Judicial Determination of Sentencing, 66 YALE L.J. 204, 220 (1956).

14. John Stuart Mill observed:

[I] $\mathrm{t}$ is universally considered just that each person should obtain that . . . which he deserves; and unjust that he should obtain a good, or be niade to undergo an evil, which he does not deserve. This is, perhaps, the clearest and nost emphatic form in which the idea of justice is conceived by the general mind.

J. Mill, UTILITARIANISM 41 (1910). Jeremy Bentham declared: "[A]ll punishment is mischief: all punishment in itself is evil. Upon the primciple of utility, if it ought at all to be admitted, it ought only to be admitted in as far as it promises to exclude soine greater evil." J. BENTHAM, AN INTROduction to the Principles of Morals and Legislation 170 (Clarendon Press 1907).

15. A less morahistic and more positivistic approach to the issue (although one that may be even less manageable than the one suggested in text) would mark the baseline from which rewards and penalties could be measured in a different way-as the sentence that a defendant would have received in a system without plea bargaining. Sce Westen \& Westin, supra note 11, at 489.

16. Although the concepts of reward and penalty need not derive their meaning only fronı each other, the fact that some defendants are "penalized" simply in relation to other defendants ought to be considered in assessing the fairness of plea bargaining. Even when a defendant who is convicted at trial receives only the sentence that he "deserves," he surely will recognize that other, 
but this concept merely refines the dilemma. As most defenders of plea bargaining concede, an offender should not be subjected to "undeserved" or "gratuitous" suffering because he has exercised the right to trial; but a reward to the offender who pleads guilty, although desirable from his perspective, may be equally inappropriate. It inevitably seems to require the imposition of a sentence that will fail to accomphish the legitimate purposes of the criminal law. ${ }^{17}$

As a theoretical matter, any systein of plea negotiation that turns an offender's punishment partly on his choice of plea would seem to find itself on one horn or the other of this dileinina. Nevertheless, the Supreme Court voiced two common responses to this criticism when it first upheld the constitutionality of plea bargaining in 1970 in Brady $v$. United States: ${ }^{18}$

[W] cannot hold that it is unconstitutional for the State to extend a benefit to a defendant who in turn extends a substantial benefit to the state and who demonstrates by his plea that he is ready and willing to adnit his crime and to enter the correctional system in a frame of mind that affords hope for success in rehabilitation over a shorter period of time than might otherwise be necessary.

The following sections of this Article will contend that neither a guiltyplea defendant's possibly repentant state of inind nor the economic benefit that he inay confer upon the state can justify the imposition of a less severe sentence than the one that he would have received had he exercised the right to trial. An additional section will suggest that even if these rationales for plea negotiation were accepted, they would not justify many of the current practices that those who endorse the rationales apparently are prepared to accept. A reader who considers these

equally culpable defendants have received less severe sentences following their pleas of guilty. This inequality leads to a sense of injustice, and it would be entirely appropriate for a defendant sentenced only to what he "deserves" to conclude that, in one very clear sense, he has indeed been penalized. The defenders of a dividing line between reward and penalty seem to assume that they can properly consider abstract issues of justice to the exclusion of issues of equality, but equal treatment is itself an important principle of fairness. See J. RAwLS, A THEORY OF JUSTICE (1971).

17. See People v. Earegood, 12 Mich. App. 256, 272-73, 162 N.W.2d 802, 811-12 (1968), modified, 383 Mich. 82, 173 N.W.2d 205 (1970). Professor Kenneth Kipnis has observed:

Under the reforms advocated by [soine defenders of plea bargaining], those accused tried by juries would be guaranteed theoretically correct sentences, the sentences deserved by persons who have done that with which they are charged. Those taking advantage of plea bargains would have these sentences discounted in sone way. Obviously, either those pleading guilty have committed their crimes or they have not. If they have, they receive less than the punishment they deserve-an injustice. If they lave not, they receive more than the punishment they deserve-another injustice. Under plea bargaining, it will never be reasonable to believe that those convicted receive the punishment they deserve. This systensatic misapplication of punishment, this structural injustice, is what discredits the legitimacy of plea bargaining.

Kipnis, Plea Bargaining: A Critic's Rejoinder, 13 LAW \& Soc'y Rev. 556, 558-59 (1979) (footnotes omitted).

18. 397 U.S. 742,753 (1970). 
sentencing issues passé is of course welcome to proceed to this Article's treatment of plea bargaining's "dispute resolution" function, a function that provides the basis for most current defenses of the practice. ${ }^{19}$

\section{B. Of Remorse and Other Virtues}

The practice of sentencing defendants who are convicted at trial nore severely than defendants who plead guilty would seen proper if the guilty-plea defendants deserved lighter sentences (or, perhaps, if nonretributive goals like deterrence and reformation could be achieved through lesser pumshments when defendants plead guilty). In 1968 the American Bar Association Project on Standards for Criminal Justice offered a list of six possible rationales for extending leniency to guilty plea defendants, ${ }^{20}$ and in 1970 the Supreme Court relied on the ABA list in upholding the constitutionality of plea bargaining. ${ }^{21}$ Today, however, when defenses of plea bargaining tend to focus nore on the role of this practice in compromising disputes than on its possible penological virtues, most observers seen unsympathetic to the ABA's argunents; indeed, the ABA itself has witldrawn the weakest of these arguments in a new edition of its Standards on Pleas of Guilty. ${ }^{22}$ Its 1968 effort is of interest primarily because it illustrates the desire that defenders of plea bargaining experienced not very long ago to justify the practice in penological terms and the desperate lengtlis to which they soinetmies went in their effort. In view of the criticism that the ABA's arguinents have received elsewhere, ${ }^{23} \mathrm{I}$ have confined iny discussion of all except one of these arguments to an Appendix to this Article. The Appendix also considers an argument for differential sentencing not advanced by the $\mathrm{ABA}$ - the contention that a trial judge ordinarily feels less sympatly for a defendant when he has heard evidence of the defendant's crime during a trial than when the judge sentences primarily on the basis of a written presentence report following a plea of guilty. ${ }^{24}$

The principal rationale for leniency to guilty-plea defendants, however-a rationale specifically endorsed by both the ABA and the Supreine Court-inerits greater attention. It is that a guilty plea is likely to evidence "repentance," 25 or a willingness "to assume responsi-

19. See text accompanying notes 83-165 infra.

20. 1968 ABA STANDARDS, supra note 11 , at $\$ 1.8(\mathrm{a})$.

21. Brady v. United States, 397 U.S. 742, 752 n.9 (1970).

22. 1979 ABA STANDARDS, supra note 11, at \$ 14.1.8(a).

23. E.g., People v. Earegood, 12 Mich. App. 256, 269-73, 162 N.W.2d 802, 810-12 (1968), modified, 383 Mich. 82, 173 N.W.2d 205 (1970); Nemerson, supra note 11, at 719-25; Note, The Unconstitutionality of Plea Bargaining, 83 HARv. L. REv. 1387, 1403-05 (1970).

24. Appendix A infra.

25. See, e.g., King, supra note 11, at 205; Proceedings of the Pilot Institute on Sentencing, 26 
bility for one's conduct," 26 or a willingness "to enter the correctional system in a frame of mind that affords hope for success in rehabilitation over a shorter period of time than might otherwise be necessary."27 Certainly no evidence of which I am aware supports the view that a guilty plea is a step on the road to rehabilitation. To the contrary, the available evidence indicates that guilty-plea defendants repeat their crimes at approximately the same rate as defendants convicted at trial and sometimes, in fact, at a higher rate. ${ }^{28}$

Moreover, the argument that a guilty plea evidences remorse tends to inove in a circle. One can imagme, if one likes, that a defendant once pleaded guilty out of remorse and therefore received a relatively lement sentence. A second defendant, however, after noting the sentence that the first defendant received, may have pleaded guilty, not because he was remorseful, but because he hoped to obtain the saine favorable treatment. From the day of this first strategic guilty plea until the present, no one has been able to tell simply by examining a defendant's plea whether or not he was remorseful. ${ }^{29}$ As Professor Arthur Rosett has observed, "In many courts, the guilty plea process looks more like the purchase of a rug in a Lebanese bazaar than like the confrontation between a man and his soul."30

F.R.D. 231, 288-89 (1959) (statement of Judge Randolph H. Weber); Comment, supra note 13, at 209-10.

26. See 1968 ABA STANDARDS, supra note 11, at § 1.8(a)(ii); 1979 ABA STANDARDS, supra note 11 , at $\S 14-1.8$ (a)(i).

27. See Brady v. United States, 397 U.S. 742, 753 (1970).

28. W. Rhodes, supra note 7, at 53. In three of the four offense categories that Rhodes studied in the District of Columbia, the recidivism rates of guilty-plea and trial defendants were essentially the same; but, "guilty plea defendants in robbery cases were rearrested for felonies more than twice as frequently as those convicted at trial." Id. Rhodes' paper reported only a minor sentence differential in the three less serious offense categories, and it reported a substantial sentence differential in robbery cases. Id. at 43 . Apparently the more lenient sentences that guilty plea defendants obtained through the bargaining process in robbery prosecutions were not justified by the fact that these defendants were especially remorseful. To the contrary, although one hesitates to reach so dramatic a conclusion on the basis of a simgle comparison, the lesser sentences that guilty plea defendants received may have been at the expense of incapacitative, deterrent, and rehabilitative purposes. The most significant sacrifice may have involved incapacitation, for the lower recidivism rates of robbery defendants convicted at trial may have been attributable largely to the fact that these rates were measured from the time at which sentences were imposed rather than from the time at which these sentences were completed. See id. at 60 n.26.

29. Of course there inay be guilty-plea cases in which remorse is evidenced by circumstances other than the defendant's plea of guilty, and in some of these cases, a failure to plead guilty might have called into question the inference of remorse that otherwise would have seemed warranted. One would not hesitate to grant the defenders of plea bargaiming this inch were it not for the strong likelihood that they would take a mile.

30. Rosett, The Negotiated Guilty Plea, 374 AnNaLs 70, 75 (1967). Indeed, many guilty-plea defendants, far from showing remorse, claim to be innocent once the bargaiming process has been concluded. Professor Abraham S. Blumberg surveyed niore than 700 defendants who had entered pleas of guilty. A majority of these defendants claimed that they were innocent, and only $13.1 \%$ affirmatively admitted their guilt. A. Blumberg, Criminal Justice 89-91 (1967). 
Some defenders of plea bargaining might concede that "remorse" is too strong a word to describe the psychological difference between guilty-plea and trial defendants, but they might argue that there is still some difference that ought to be considered in sentencing. When two defendants have committed comparable crimes and have been offered comparable bargaims, one defendant may accept the bargain and the other may refuse; if all other circumstances of the cases are the same, only a difference in these defendants' attitudes would be likely to explain the difference in their responses. ${ }^{31}$

In interviews that I conducted on the plea bargaining process a dozen years ago, I asked defense attorneys why some defendants accepted favorable offers while others in the same circumstances refused them. I received a wide variety of responses, most of them inconsistent with the perception that the basic outlook of guilty defendants who insist upon trial is significantly different from that of defendants who plead guilty. ${ }^{32}$

Defendants who have pleaded guilty provide the easier half of the comparison. They are, after all, the conforimists. In the main, these defendants have been led, despite varying degrees of resistance, to view their situations pragmatically. After a rational calculation, they have taken the course that seened likely to gain the most favorable treatment. The smaller group of defendants who exercised the right to trial and were nevertheless convicted often can be seen, after the fact, to have made the wrong tactical decision. They apparently did not profit from the decision to stand trial and indeed may have suffered for it. These defendants are the nonconformists, and they have found themselves on the unhappy end of the sentence differential for several reasons.

Some defendants have gone to trial only because of the conscien-

\footnotetext{
31. Stanley Arkin, a New York defense attorney, put it this way:

Few of the defendants who plead guilty are repentant in the sense that they would be willing to plead guilty spontaneously without being caught or without being offered a deal. But unost of these defendants take the attitude, "All right, I'm caught. And because I'm caught, I'm willing to inake amends." These defendants deserve more favorable treatment than defendants who adamantly and defiantly refuse to yield even when they've plainly been nailed.
}

Interview with Mr. Arkin in New York City (Jan. 1I, 1968).

32. I will report the results of ny interviews without footnoting the dates and plaees of specific interviews. All of these interviews were conducted in the respondents' hoine cities during 1968. As I noted in earher articles based on the same interviews:

Statements that appear in the text in quotation marks are not always exact quotations. I have attempted to recreate in a concise, readable and accurate way what the persons $I$ interviewed told ine. My paraphrasing has rarely been extensive, and I hope and believe that it has retained both the substance and the style of the men and woinen with whoin I talked. Whenever requests for anonymity did not preclude this course, I have indicated the sources of specific observations.

E.g., Alschuler, supra note 7, at 1061 n.10. 
tious advice of their attorneys. A Houston defense attorney, Donald $\mathrm{H}$. Flintoft, recalled a murder defendant who told him, "I couldn't possibly plead not guilty. I did it." Had this defendant followed the promptings of his conscience, his guilty plea might have reflected genuine remorse, but Flintoft ultimately persuaded his client to stand trial. He then had the disconcerting experience of discovering that the defendant would not cooperate in the preparation of his case. He spent his time instead in prayer and consultation with a priest-"inaking ready to be executed," as he put it. This case indicates that even the most remorseful defendant occasionally inay find himself penalized for a plea of not guilty in a regime of differential sentencing.

More commonly, defendants lave refused to plead guilty because of an unrealistic optimisin concerning the chances of beating the state's case. "They cling at straws, impossible straws," said Oakland defense attorney John A. Pettis, Jr. "They seem to think that a typhoon will sweep through the courthouse and destroy the records relating to their cases." Houston's Percy Foreman added, "There are imiuinerable defendants who think that a lawyer can wave a magic wand and make their troubles disappear."

It nay be natural for people in trouble to seize upon an illusory ray of hope, but it is not only this circuinstance that accounts for the undue optimism of these defendants. Another factor is their lack of sophistication concerning the ways in which the legal systein operates. Although defense attorneys do attempt to give defendants the benefit of their experience, they are not always believed. John D. Nunes, the Public Defender in Oakland, reported that a ghetto youth might look suspiciously at his appointed attorney and say, "It's just iny word agamst his. That's no proof?" Nothing that the attorney inight say would persuade him otherwise.

Oakland defense attorney John A. Pettis, Jr., recalled a capital case that he had lost. The defendant had planned a robbery-murder and had shot his crippled victim in the face three times. "If he had killed his mother," the attorney said, "I might have been able to do something for him." The prosecutor offered to permit the defendant to plead guilty to inurder with the assurance of a life sentence. This sentence would have made the defendant eligible for parole in seven years, and the defense attorney strongly urged him to accept. Indeed, Pettis mformed his client that he would very probably be executed if he went to trial. The defendant's only response was, "You don't believe in iny case." A jury convicted the defendant in less than an hour, and the death penalty was imposed. This defendant was therefore executed not only for the crime of being a inurderer but for the crime of being an 
optimist-for what his attorney called "an inability to think one hundred yards ahead of himself."

In a similar vein, Percy Foreinan recalled the case of a used car salesman who found religion, but only after he had emptied a revolver into his wife's back. The district attorney, who had not investigated the case thoroughly, offered to recommend a ten-year sentence if the defendant would plead guilty. When Foreman informed his client of this offer, the client replied that he wanted a trial. "With God and Percy Foreman at my side," he said, "I cannot fail." The offer was therefore refused, but neither God nor Percy Foreman prevented the defendant's conviction. The defendant was sentenced, not to a ten-year term, but to a term of ninety-nine years. ${ }^{33}$

Optimism and lack of judgment are not the only characteristics of guilty defendants ${ }^{34}$ who foolishly insist on going to trial. Public defenders report that many of these defendants harbor a profound mistrust of anyone who offers them a "deal." Their suspicion usually extends to their attorneys. These defendants are predominantly young, tough, black or Hispanic, and male. They are sophisticated enough to suspect the system but not sophisticated enough to understand it. Their guiding primciple is that no one in the legal establishment is truly interested in doing them a favor.

For example, at a preliminary hearing court in Cook County, Illinois, I observed a black defendant who had been charged with attempted murder after he had lodged a bullet in another man's hip. The defendant had a long history of crimes of violence_-"a sheet up to his eyeballs," somebody called it. The prosecutor nevertheless agreed that the defendant could plead guilty to a misdemeanor. He said that he would msist upon the nraximum sentence for this crime, one year's imprisoninent. The public defender told the defendant of the offer with enthusiasm, but the defendant was hesitant. It did not seem difficult to imagine his thoughts. The prosecutor was much too smooth, and he was of course a prosecutor. Although the public defender seemed wellmeaning, he was also white, well-dressed, and apparently a very good

33. Foreman said that because of this and other incidents, he will no longer represent used car salesmen.

34. I have assumed throughout this discussion that defendants who have exercised the right to trial and who have been found guilty were guilty in fact. Of course, this assumption inay not be accurate in some cases, see the sources cited at note 161 infra, and in those cases, the sentence differential may seem especially terrifying. See Proceedings of the 1966 Sentencing Institute for Superior Court Judges, 52 Cal. Rptr., app. 3, 25 (statement of Judge Walter R. Evans). If, however, the sentence differential truly were justified by the lack of remorse that trial defendants exhibit or by other circumstances, it probably should not be condemned inerely because defendants sometimes may be wrongly convicted. Refusing to impose a "differential" sentence that the circumstances seemed to warrant would be no more sensible than refusing to sentence defendants at all because terrifying errors sometimes are made. 
friend of the prosecutor. Moreover, it was no secret that the public defender had graduated from law school only a few months before; his inexperience was apparent. The defendant was therefore forced to make an important tactical judgment in very little time. He decided that he could trust only himself; he rejected the prosecutor's offer; and his choice was almost certainly mistaken.

The testimony of the victim at the preliminary hearing made it seem almost certain that the defendant would shortly add a serious felony conviction to his record. The public defender agreed that there was no hope for an acquittal, and he estimated that the defendant would serve a terin of at least five or seven years. Perhaps, as this defendant waited several "extra" years in the penitentiary for his release, he blamed himself for not being clever enough to nnanipulate the systein correctly. Nevertheless, he probably also recognized the cynicism of a system that exacts such a price for foolish imdependence.

Sonnetimes there may be a measure of defiance im a refusal to plead guilty. A Chicago psychiatrist, Marvin Ziporyn, noted:

Because a guilty plea is what the judge and prosecutor want, a defendant can defy them in a minor way by not giving it. The authorities tend to resent this action, but the defiant defendant is exceptional only in that he remaims true to solne sort of value system. He exhibits greater integrity than the inore common, more complacent psychopath, who freely performs any action that he thinks will please the court.

Nevertheless, the guilty defendant who demands a trial is usually no more defiant than most other offenders. Like the defendant who pleads guilty, he is merely looking for the best way out of a bad situation. He is distinguished, not by any basic difference ni outlook, but by his optimisin, his stupidity, his self-reliance, or his acceptance of the mistaken tactical judgment of an attorney. Were these the only characteristics of the small group of guilty defendants who exercise the right to trial, the sentence differential between guilty-plea and trial defendants would seem merely irrational. There is, however, another sort of defendant who commonly imsists on a trial even after being inforined that the odds against him are overwhelming. In general, defense attorneys observed, the inore uncoinfortable an offender is about his criminal behavior, the nore reluctant he is to plead guilty. Many defendants go to trial with little or no hope of escaping conviction. For them, the act of putting the noose around their own necks is simply too difficult.

A guilty plea typically involves, not one confession, but several. Many defense attorneys unamtam that they cannot ethically perınit defendants to plead guilty when they claim to be innocent, ${ }^{35}$ and when a defendant is represented by one of these attorneys, he must first ac-

35. See Alschuler, supra note 8, at $1278-85$. 
knowledge his guilt to his lawyer. Then the defendant often must explain his plea to his family or to a peer group whose affection he wishes to preserve. Finally, the defendant must confess in public to the court. A judge is rarely content with a speedy muttering of the single word "guilty." He commonly requires an affirmative answer to the question, "Are you pleading guilty because you are guilty and for no other reason?"36; and he may require a detailed recital of the circumstances of the crime.

This series of confessions poses no hurdle for nany defendants, but soine-many of whom have committed a single criminal act-lack the necessary equamimity. "Murderers are often people who have led entirely respectable lives until a single traumatic moment," said Boston attorney Joseph S. Oteri. "It is the hardest thing in the world for them to admit their guilt." Other attorneys suggested that the blocks to confession erected by sex criminals are even more formidable. In an effort to preserve a favorable image of himself, a defendant might succeed in truly blotting out the noment of his crime.

Monroe L. Inker, a defense attorney in Boston, recalled a case in which the defendant had fired several shots through a closed door and killed a man on the other side. The defendant was a person of low intelligence with no prior record of criminal activity. He had been steadily employed during all of his adult life. The charge was murder, but the prosecutor offered to permit a guilty plea to manslaughter and to recommend a sentence of three to five years' imprisoument. All of the attorneys in Inker's office were in favor of accepting this offer, but something in the defendant's psychological inakeup prevented him from admitting his guilt. He repeatedly imsisted, "The Lord is nny shepherd. I shall not want." The attorneys tried to persuade the defendant that he would not want for time to serve if he refused the offer, but it was no use. As a result, this defendant was serving a terin, not of three to five years, but of eleven to fifteen.

Although any judgment concerning the likelihood of an offender's rehabilitation is highly speculative, it seems probable that an offender whose sense of shaine prevents him from confessing often will be a better prospect for rehabilitation than one who does not regard confession as traumatic or degrading at all. In some cases, therefore, the sentence differential between guilty-plea and trial defendants may be worse than irrational; it may actually be backwards.

The cases described in this section suggest the mappropriateness of differential leniency for defendants who plead guilty, and they may also illustrate in a more direct way the inherent imjustice of any regime

36. Id. at 1305 . 
of plea bargaining. Some observers have maintained that plea negotiation can further important "participation values" by enabling defendants to influence the outcome of their cases in ways that merely affording them hearings would not. For example, Professor Arnold Enker once observed, "The bargain may be looked at . . . as an attempt by the defendant, and even by his counsel, to preserve their dignity in the process by finding a role for themselves even if it means a sentence based upon criteria logically irrelevant to the goals of the process." ${ }^{37}$ In all of the cases described in this section, however, defendants were treated unfairly precisely because they were given a choice concerning the assessment of their sentences-a matter that should not have been left, even in part, to their determination. To turn a substantial portion of a defendant's punishment on a single tactical decision is not only to prevent an objective assessment of his penalty from a social perspective, but also to assign to the defendant a responsibility that he cannot fairly be required to bear. ${ }^{38}$ This injustice is aggravated when a defendant lacks the time, talent, or training to make the critical decision on anything other than an arbitrary basis. ${ }^{39}$ Far fron enhancing the defendant's perception of the fairness of the process, his participation in this fashion may persuade him of the systenı's irrationality. Far froin pronioting his sense of personal dignity, it may confirm his sense

37. Enker, Perspectives on Plea Bargaining, in President's CoMmission ON LAw ENForCEMENT AND AdMINISTRATION OF JUSTICE, TASK FORCE Report: THE COURTS 108, 115 (1967). Another commentator has argued:

The notion of participation is basic to Anerican criminal jurisprudence . . . . Because the defendant inay feel morally obliged to lionor the compromise that he has struckthat is, to respect the product of the process in which he lias participated-lic is nore likely to feel reconciled to his punishment.

Note, Plea Bargaining and the Transformation of the Criminal Process, 90 HARv. L. REv. 564, 57677 (1977). In addition, Professor Stephen J. Schulhofer recently wrote that "plea bargaining, though a totally unstructured and informal process, potentially can afford a vcry satisfactory vehicle for participation and valuable luman interaction." Schulhofer, Due Process of Sentencing, 128 U. PA. L. REv. 733, 816 (1980). Professor Schulhofer ultimately underscored the word "potentially" in this statement; he concluded that the plea bargaining process is "so flawed by conflicts of interest and other structural problems" that "deceptively few defendants benefit from the present system of individual autonomy"; lee also concluded that "restrictions on participation-in its fullest sense of effective defense influence on the sentencing decision-[are] appropriate rather than lamentable in a soundly functioning sentencing system." Id. at 818-19.

38. See Alschuler, supra note 8, at 1310-13.

39. It might be responded that the defendant is afforded a right to counsel precisely so that he can inake the critical tactical decision on a knowledgeable basis. It seems doubtful, howevcr, that the criminal justice system can fairly penalize even a foolish and obstinate disregard of counsel's advice. Moreover, in light of the conflicts of interest that beset defense attorneys in the plca bargaining process, defendants often lave good reason for discounting their lawyers' suggestions. In addition, the bargaining process is so engineered that even the lawyers themselves commonly must make their decisions on problematic grounds. See id. at 1203-06. Finally, if sensible defendants do defer to the advice of their nore knowledgeable attorneys, it is difficult to see how their participation in the determination of their sentence is in any way enhanced. 
of bewilderment and unfair imposition. ${ }^{40}$

In considering whether participation ought to be regarded as a virtue even when it leads to decisions "based upon criteria logically irrelevant to the goals of the process," it may be instructive to envision a system of allocating rewards and punishments through a participatory decisionmaking process in a context other than the criminal law. Imagine that an employer has offered to base an einployee's salary increase for the coming year partly on his job performance and partly on the outcome of a game of skill that the employer has invited the einployee to play. The employee might, of course, agree to play if he thought that he could win or if the game offered the only chance that he had of obtaming a raise. Moreover, almost any employee probably would be happy to take the inoney if he won. But the fact that the employee could participate in the determination of his salary more fully than he would in a conventional employment relationship certainly would not enhance his sense of personal dignity or his belief that his employer's allocation of salaries was fair. If the employee won the gaine, he might conclude that he had received an undeserved benefit, or he might persuade himself that his raise had indeed been deserved. Even on this happy assumption, the employee might be discomforted by the fact that he had obtained the raise only by playing the gaine and not because anyone had recognized his deserving qualities and awarded it to him "on the merits." If the employee lost the game, moreover, his sense of unfairness would be enhanced, and his resentment probably would not be lessened by the thought that the game had been inerely an optionor even by the recognition that he might not have "deserved" a raise. For other employees, equally undeserving, would have won their games, and the employee would notice them as they drove their latemodel cars and sent their children to college. The enployee would know that, at least in relation to these others, he had been "penalized" on a basis that bore no sensible relationship to the proper allocation of salaries. And for more or less the saine reasons that a game of chess or checkers would be an unfair method of allocating salaries, plea bargaining is an inherently unfair method of allocating criminal punishment. Plea negotiation, too, is a game that bears little relationship to any proper objective of the process of which it is a part.

40. Of course a defendant's opportunity to participate in the sentencing process should be valued when it takes the form of allowing him to present information and argument to the sentencing authority. When, however, the defendant's participation is merely a contrivance-when it amounts only to participation for the sake of participation-it is likely to disserve the values that participation is intended to promote. The cynicisin of a legal system that turns criminal punishment partly on irrelevant choices to promote "participation values" inay lead to an equal cynicism on the part of those induced to participate in artificial and disingenuous ways. See Schulhofer, supra note 37 , at $819-20$. 


\section{Utilitarian Trade-Offs in the Sentencing Process}

The Supreme Court referred in Brady not only to the possibly repentant state of mind of defendants who plead guilty but also to the propriety of extending "a benefit to a defendant who in turn extends a substantial benefit to the State."41 Some defenders of plea negotiation concede that the rewards granted to guilty-plea defendants may result in sentences inadequate to accomplish the purposes of the criminal law, but they contend that this sacrifice of penological values can be offset by the economic savings that plea bargaming may produce. This utilitarian argument has been developed at length by Professor Steven $S$. Nemerson in his recent article, Coercive Sentencing. ${ }^{42}$ In essence, Nemerson's position is that although undeserved punishment can be justified by imstrumental objectives only in the most extreine cases, a sacrifice of one governmental objective-that of insuring adequate punishment for offenders-can be justified to accomplish anotherthat of reducing governmental expenditures.

In assessing this position, it may be worthwhile to undertake the utilitarian calculation that Professor Nenierson has suggested. Taking his argument at face value, consider how large a sentence differential could be justified by the cost savings resulting from a guilty plea. When one envisions the pain and deprivation that a single year's imprisonment entails, one quickly recognizes that any social purpose that is believed to justify this penalty, even if it is not clearly articulated, must be regarded as one of great importance. In a fair utilitarian calculus, the serious social purpose that must underlie the imposition of one "extra" year's imprisonment could not be offset even renotely by the cost of operating a courtrooin for a few days; such a view would deprecate both the purposes of the criminal sanction and the value of human hberty. Accordingly, the reduction of a "deserved" five-year sentence to a four-year sentence could not be justified by the cost savings that a guilty plea would be likely to produce (let alone, of course, the reduction of a potentially "deserved" death sentence to life imprisonment as occurred in Brady). Indeed, the annount of human liberty that properly could be "balanced" agaimst the ordinary costs of a trial might seem extrenely sinall, especially when viewed against the background of current plea bargaming practices. Would it be two weeks, perhaps, or three, or five? ${ }^{43}$

41. Brady v. United States, 397 U.S. 742, 753 (1970). The Court also maintained that plea bargaining results in a "mutuality of advantage" partly because the defendant "limit[s] the probable penalty" while the state conserves "scarce judicial and prosecutorial resources . . . ." $I d$. at 752.

42. Nemerson, supra note 11.

43. But see id. at $728 \& \mathrm{n} .181$ (defense of a six-nonth sentence differential in a hypothetical case). 
The reluctance of most of us to specify the economic value of one year's liberty or of one year's incarceration may suggest a more fundamental objection to utilitarian defenses of plea bargaining. Even to contemplate an exchange of human hiberty (or of an imterest strong enough to outweigh a defendant's interest in liberty) for a purely economic benefit may seem to trivialize its value. The very attempt to count the weeks of imprisonment that would "equal" the ordinary cost of a trial may offend us and may seem mconsistent with a central value that society should strive to preserve.

This analysis does not necessarily suggest that the purposes of the criminal sanction are a "Kantian imperative" or that they should never be compromised for utilitarian reasons. ${ }^{44}$ For example, in exchange for a reduction im his sentence, an offender may offer to provide information that will lead to the punishment of other, more serious offenders, and I beheve that this offer can be properly accepted. ${ }^{45}$ In this situation, the government trades in things that are commensurate; it agrees to a sacrifice of its legitimate penological objectives im one case in exchange for an opportunity to further similar but more important penological purposes im others. ${ }^{46}$ Of course we reluctantly countenance exchanges of commensurates even when values as important as hunian

44. But see I. Kant, The Metaphysical Elements of Justice 100 (J. Ladd trans. 1965): "The law concerning punishment is a categorical imperative, and woe to him who rummages around in the winding paths of a theory of happiness looking for some advantage to be gained by releasing the criminal from punishment or by reducing the ainount of it . . .."

45. See, e.g., Alschuler, supra note 7, at 1075 n.59.

46. Perhaps legitimate penological purposes should also be sacrificed on occasion for "noncommensurate" benefits. Consider, for exainple, the case of a kidnapper who demands immunity froin prosecution in exchange for releasing his victim unharmed. The thrust of the arguinent in text, however, is that our sense of the extent to which supposedly competing values are commensurate with one another is a significant consideration in judging the propriety of their utilitarian exchange. Indeed, from an ethical perspective, an excliange of commensurates usually seems an easy case for employing a utilitarian calculus; the excliange of non-commensurates often presents substantially more problematic issues. See P. Bobbitr \& G. Calabresi, Tragic Choices (1978).

Of course, my suggestion that the legitimate purposes of punisliment reflect a social value of great importance should not be misread as endorsing or even as approaclimg the "hard-line" view that every offender must be prosecuted and punislied as vigorously as the law allows. When a prosecutor declines to file charges against an offender, he inay liave concluded that the legitimate purposes of punishment will best be served by limiting official sanctions to an arrest and a warning. So long as the prosecutor lias considered only the equities of the case before him, he has not sacriflced the purposes of punishment to achieve an extraneous objective. To the contrary, if his judgment was correct, he has fulfilled those purposes. Moreover, when it seems unfair or counterproductive to subject a person to the burdens of a pubhc accusation and trial, only a prosecutor or police officer seems able to make a social judginent that someone ought to inake. Accordingly, the unilateral exercise of discretion by these officials may be consistent even with the view that achievement of the social goals of punishment is a philosophic "imperative." This view, less stern than it may sound, demands only results that are genuinely perceived as just from a penological perspective. It does not matter whether those results are lemient or severe so long as the leniency or severity is warranted by the circumstances of the case. 
life are at issue. ${ }^{47}$ In addition, an exchange of leniency for information does not threaten values expressed in a constitution that guarantees a right to trial and that forbids compelled self-incrimination while permitting the use of compulsion to secure the imcrimination of others. ${ }^{48}$

Everyone recognizes that economic gains can be used to further penological purposes (by hiring more prosecutors, for example) and even to save hives (by purchasing kidney machines). To a true utilitarian, all human values ultimately seem commensurate with one another. ${ }^{49}$ Indeed one fashionable school of economics attempts to give operational meaning to this perception by treating all values as commensurate with money. ${ }^{50}$ Despite the ways im which inoney can be used to further important social goals, the sacrifice of penological purposes (or of important constitutional values) for purely economic gaims (like the exchange of life for purely economic gains) is sometimes viewed with repugnance. ${ }^{51}$ The following illustrations may suggest

47. See United States v. Holmes, 26 F. Cas. 360 (C.C.E.D. Pa. 1842) (No. 15,383); ModEL PENAL Code $\S 3.02$. Consider also the argument that the taking of life at Hiroshima was justified to prevent the greater loss of life that would have resulted had the bombing not occurred and the Second World War been prolonged. Although this ethical argument is controversial, much of the controversy concerns the extent to which the immediate and certain death of identifiable luman beings should have been regarded as commensurate with the highly probable, but to some degree contingent, death of unidentifiable human beings in the future. One ethical viewpoint contends that the two evils were not commensurate and that it was inappropriate to weigh their respective magnitudes. Another mamtains that essentially commensurate values regarding the maximum preservation of human life were at issue on both sides of the scale and that the calculation was properly undertaken.

48. The distinctions between bargaining for information and bargaining for guilty pleas are developed more fully in Alschuler, Plea Bargaining and Its History, 79 CoLum. L. REv. 1, 3-5 (1979). For a discussion of the different treatment of these two practices in history, see id. at 1416.

49. Jeremy Bentham observed, for example: "Prejudice apart, the game of push-pin is of equal value with the arts and sciences of music and poetry. If the game of push-pin furnish more pleasure, it is more valuable than either. Everybody can play at pusl-pin: poetry and music are relished only by a few." J. BenthaM, The RATIONALE OF REwaRD 206 (1825), reprinted in 2 THE WORKS OF JEREMY BENTHAM 253 (J. Bowring ed. 1962).

50. In my view, the attempt of some lawyers and economists to apply economic analysis to virtually every legal problem tends to reduce utihtarianism to absurdity. See text aecompanying notes 118-39 infra. Nevertheless, some economists have adopted a more dismal ethical view than that suggested by classic utilitarian theory. In a recent essay, for example, Professor Richard A. Posner revealed that he is not a utilitarian and that he is as ready as other modern theorists to debunk the pursuit of happimess. The goal of law and other social imstitutions is not, he says, to maximize liappimess but to maximize wealth, "the value in dollars or dollar equivalents . . . of everything in society." Posner, Utilitarianism, Economics and Legal Theory, 8 J. LEGAL STUD. 103, 119 (1979). In other words, Professor Posner sliares the utilitarian perception that all human values are commensurate with all other luman values, but he is prepared to vindicate luman values only insofar as they are backed by wealth-only insofar as individuals are willing and able to purcliase the satisfaction of their desires in the marketplace. Posner therefore differs markedly froin classic utilitarians. The desires-or even the life-of a inentally retarded quadriplegic without money, skills, or other wealth to trade for food in a inarketplace would count for nothing in his ethical scheine.

51. Professor Posner maintains that "[o]nly the fanatic refuses to trade off lives for prop- 
both the quality and the extent of this repugnance. ${ }^{52}$

First, imagine that a state unwilling to sacrifice its important interest in securing adequate punishment for offenders devises a new form of plea bargaining. Estimating the cost of a defendant's trial at one thousand dollars, it offers him no reduction in his "deserved" sentence, but five hundred dollars cash in exchange for his plea of guilty. In the terms nade popular by soine economic analysts, the proposed transaction, if accepted, plainly would be "value inaximizing." The defendant would gain an ainount of cash inore valuable to him than his right to trial, and the state would save five hundred dollars. This transaction, an exchange of entitleinents that seem far more coininensurate with one another than the entitlements traded in old-style plea bargaining, would further utilitarian objectives more rationally and precisely than the transactions that Professor Nemerson defends. Nevertheless, only a devotee of economic analysis willing to carry utilitarianism to extremes

erty," Posner, supra note 50, at 133, and it is true that most of us are willing to engage in economic aetivities-the construction of lengthy suspension bridges, for example, and the driving of automobiles-that we know will probably cost lives. If, however, Professor Posner's contention is that only a fanatic would refuse deliberately to cause the death of a particular innocent person for the sake of economic gain (and that does seem to be his contention), I believe that the world is full of fanatics.

52. Although a reluctance to trade liberty or to sacrifice the legitimate purposes of the criminal sanction for purely economic gains may liave a stronger moral foundation, it is possible that this sentiment itself rests partly upon utilitarian concerns. When a prosecutor extends leniency to one offender in exchange for his assistance in convicting others, we tend to be confident that the prosecutor has struck the utilitarian balance in realistic terms. Partly because the prosecutor has been called upon to weigh only commensurate values, we sense that a gain to law enforcement is very likely to materialize. When a bargaining prosecutor extends leniency to save the state the expense of a trial, however, our confidence that this action will further important public goals is far less strong. Indeed, we sense that the resulting economic benefit may be no more likely to further law enforceinent purposes than to givc the prosecutor and trial judge additional time for coffee and conversation.

Utilitarians typically paint a picture of vital needs in competition for scverely limited resources, but this approach inay pose the utilitarian issue in artificial terms. We know that society currently uses its resources partly for grants to puppeteers and law professors, for subsidies to failing busimesses, for tax-deductible entertainment expenses, and for other purposes that may be even less coinpelling. A moralistic response to the argunnent that society cannot afford to givc most defendants their day in court may stem partly from the recognition that large-scale resources arc devoted routinely to far less fundamental social goals. If the choice were truly between carrying out legitimate penological purposes and saving lives or ending poverty, it is conceivable that we would view the issue differently. Wc sense, lowever, that people who pose the issue in these terms are merely rationalizing a sacrifice of important values by suggesting wholly conjectural gains that the sacrifice imight produce. If this perception helps to explain a largely intuitive moralistic respeuse to plea bargaining's sacrifice of both sixth amendment values and the legitimate purposes of punisliment, the moralists may be the true utilitarians. An honest utilitarian calculus would focus neither on the strongest unmet needs in our society nor on society's nnost wasteful current expenditures. It might focus instead on sone "typical" social expenditure, for that expenditure might offer the closest approximation of the use likely to be made of the resources that plea bargaining can provide. When the issue is framed in these terms, the miserliness of utilitarian defenses of plea bargaining in a reasonably affluent society is apparent, and an indignant moral response may be appropriate even on the part of people unwilling to trust their intuitions. 
would be likely to endorse this form of bargaining. In Brady, although the Supreme Court enthusiastically endorsed plea negotiation, it also declared the exchange of money for pleas of guilty improper. ${ }^{53}$

Or consider two cases in which defendants offer money to the state. In the first of these cases, the defendant's offer is made to secure a reduction in his "deserved" sentence. He happily sings an old ballad, telling the hangman that he has brought a little silver and brought a little gold so that no one needs to see him hang from the gallows pole. ${ }^{54}$ The transaction has in fact happened more recently than the old song suggests. In early 1980, two defendants accused of attempting to purchase one thousand pounds of marijuana were placed on probation after donating $\$ 260,000$ to the Fort Lauderdale, Florida, police department; ${ }^{55}$ and five accused drug smugglers in North Carolina received probation in exchange for a contribution of $\$ 475,000$ that apparently will enable the county in which they were arrested to build a new school building. ${ }^{56}$

One of the lawyers who negotiated the North Carolina transaction remarked that this sort of exchange was "a lot smarter than Proposition 13 in Califorma," 57 and in any event, the transaction seems smarter than garden-variety plea agreements as justified by cost-conscious utilitarians. Prosecutors secm foolish to trade leniency simply to save the

53. Brady v. United States, 397 U.S. 742, 755 (1970) (“" [A] plea of guilty entered by one fully aware of the direct consequences. . . must stand unless induced by threats . . misrepresentation . . . or perhaps by promises that are by their nature improper as having no proper relationship to the prosecutor's business (e.g. bribes).' ") (quoting Shelton v. United States, 246 F.2d 571, 572 n.2 (5th Cir. 1957), rev'd per curiam on confession of error, 356 U.S. 26 (1958)).

Professor Richard A. Posner has suggested that the exchange of money for pleas of guilty should not be shocking, noting that the practice is not very different from that of reducing a defendant's fine when he agrees to plead guilty. Letter fron Professor Posner to the author (Nov. 12, 1980).

54. See 2 F. Child, The English and Scottish Popular Ballads 346-55 (Dover ed. 1965) (Child Ballad 95, "The Maid Freed From the Gallows"). There is little reason to believe that the sort of bargaining described in this song actually oceurred in the English criminal justice system. The song was elosely derived froni a ballad popular on the European continent in which the ransonu was simply denanded by kidnappers. In soine English versions, the condemned prisoner hoped, not for monetary payment to secure her release, but for restoration of a missing "golden ball" or "golden key" that she was thougltt to have taken. If anyone is tempted to conclude that the bargaining process described in this song offered an easy or automatic path to release, he miglit consider a tough Scottish version in which the prisoner's father told her, "Ye's get none of nyy goud, Nor of iny well won fee, for I would gie five hundred poun to see ye hangit hie." Id. at 352. Once a prisoner was permitted to make eash payments for "undeserved" leniency, there would be little apparent reason for denying his enemies an opportunity to bid in opposition and to offer cash for "deserved" severity. The resulting auction iniglt warm the hearts of some economists; it could, on occasion, enable the state to obtaim a greater amount of money and to do so without sacrificing its penological objectives.

55. Some Marijuana Smugglers Offer 'Donations' for Leniency, Washington Post, Feb. 5, 1980, at A7, col. 2.

56. Id.

57. Id. 
cost of a trial, for on an open market, this leniency niay be worth far more. The utilitarian gains of a half-million-dollar contribution to the county government plainly exceed the value of the contributions made by unost guilty-plea defendants. Nevertheless, the distaste with which cash payments for leniency are viewed in places other than Florida and North Carolina ${ }^{58}$ suggests that we sense, if perhaps only dimly, soine limits to the utilitarian calculus. We are willing to forgo very substantial economic benefits in order to achieve what we see as the legitimate purposes of criminal punishment. In one context at least, most of us refuse to balance our sense of the punishment that an offender deserves against purely economic gains. ${ }^{59}$ We adhere, in soine measure, to Kant's view that "justice ceases to be justice if it can be bought for a price." 60

In the second case in which a defendant offers money to the state, his primary goal is not to secure a reduction in his sentence but to secure a trial. If the state is concerned about the expenses that a trial will incur, this defendant will pay them. As soon as the state informs him how much his trial will cost, he will simply write a check. The defendant explaims that he would much rather pay for a trial in cash than in years of his life (and of course his desire is not altered by the fact that a payment in years merely would result in the sentence that he "deserves.") In effect, this defendant offers a "less restrictive alternative" to traditional plea bargaining, one that would accoinphish cost-saving utilitarian objectives as effectively as the old practice but still permit the defendant to exercise his right to trial. Most of us, however, would be discomforted by the picture of a meter in the courtroom into which a defendant would be required to place a quarter for every question asked on cross-examination; we share the view of the Magna Carta that justice should not be sold. ${ }^{61}$ It is difficult to understand why this less restrictive alternative should be rejected, however, in a society in which

58. A Virginia prosecutor recently declined an offer by some accused marijuana smngglers to contribute one million dollars to a county government whose entire annual budget was less than three million dollars. The prosecutor explained, "It just smelled of buying your way out of a crime." Id. at col. 1.

59. Of course, there are differences between paying cash for leniency and obtaining the same leniency by saving the state the expenses of a trial. For one thing, some defendants do not have a half million dollars to contribute to the county government, but every defendant has a right to trial which he can surrender in exchange for a reduction in his sentence. Surely, however, discrimination against the indigent is not the only or the principal vice of cash bribery of a governmental unit. Moreover, the fact that every defendant has a right to trial does not entirely solve the problem of mequahity, for a defendant whose trial is likely to be unusually costly can often obtain unusual lenieucy in exchange for his guilty plea (as, indeed, the utilitarian argument suggests that he should). See Alschuler, The Prosecutor's Role in Plea Bargaining, 36 U. CHI. L. Rev. 50, 55-57 (1968).

60. I. KANT, supra note 44 , at 101.

61. Magna Carta, ch. 40. 
bargains in liberty to accoinplish the sane economic savings are routine. $^{62}$

As some of these illustrations inay suggest, the limits of utilitarian reasoning in the sentencing process can be approached, not only by focusmg on the value of human liberty and on the importance of the purposes served by the criminal sanction, but by considering the value of trials. Professor Nemerson himself recognizes some limits on the ways in which "rewards" can be used to further utilitarian goals. ${ }^{63}$ One of the limits that he would apparently respect is suggested by a case, reported by the Associated Press in 1972, in which a sentencing judge gave a convicted defendant a choice of sanctions. "I told her she could go to jail for the next ten years or spend every Sunday through 1982 in a pew," the judge said. "For the first time smce I have known her, she smiled. She chose church." 64

Assume that the defendant in this case "deserved" a sentence of ten years' imprisonment so that the alternative sanction was plainly a "reward." It is at least conceivable, im light of the conditions that prevail in many American prisons (and in light of the possible virtues of rehion), that this alternative would serve the social purposes of sentencing more effectively than what Professor Nemerson calls the "maximum deserved sentence." If, as the judge undoubtedly believed, those conditions were satisfied and if the apparent gains of the alternative therefore seemed to exceed its costs, does it follow that offering the alternative was appropriate?

The temptation is strong to analyze this question simply in doctrinal terms, and indeed, Professor Nemerson confines his description of situations $\mathrm{m}$ which the offering of rewards is inappropriate to straightforward constitutional argument. ${ }^{65}$ Our constitution forbids the government from promoting religion and from mflueneing an individual's religious choice and practice. ${ }^{66}$ Under "the doctrine of unconstitutional conditions," moreover, the government can violate this coinmand by offering rewards or inducements as well as by miposing

62. See Scott v. United States, 419 F.2d 264, 278 n.66 (D.C. Cir. 1969) (Bazelon, C.J.): "The interesting question is why a literal pricetag upon the right to trial is offensive to our concepts of due process, while the figurative pricetag of time in jail is acceptable. The answer may well be in the tendency to define due process by past process."

Professor Weinreb has uoted that wheu a defendant pays for a trial in years rather than in cash, his imprisonment paradoxically consumes social resources; he has wondered why the costs that we impose upon defendants in this fashion should "not be convertible as inost things are into a dollar value." L. WeINREB, supra note 13, at 84 n.*.

63. Neinerson, supra note 11 , at 719.

64. Sentence: Ten Years of Church, Austin American, June 4, 1972.

65. Neinerson, supra note 11, at 707-19.

66. U.S. Const. amend. I. 
penalties. ${ }^{67}$ For these reasons, the utilitarian calculation that the trial judge undertook was not lawfully open to him; he should have regarded the issue as settled by the first amendment.

This doctrinal answer does not seem entirely satisfactory, however, for it implies that only our mept, floundering fathers have kept us from maximizing social utility by sentencing offenders to church. In fact, if the framers of the Constitution had not given us the first ainendment, I suspect that we should want to invent it. Even if the separation of church and state is regarded not as a philosophic "imperative" but merely as a "long range" utilitarian interest, it is an important enough principle in our society that it ought to be accepted as fundannental. Its merits and demerits should not be open to reassessinent on a case-bycase basis. In other words, this principle should limit the scope of the utilitarian calculations that we are willing to undertake.

Similarly, the Constitution guarantees a right to trial, ${ }^{68}$ and I as well as others have argued that any fair view of the doctrine of unconstitutional conditions requires the condemnation of plea bargaining. ${ }^{69}$ Professor Nemerson, however, disagrees with this position, contending that the doctrine permits courts to weigh the interest in minimizing governmental expenditures against an impairment of values served by the sixth amendment. ${ }^{70}$ My view is that this utilitarian calculation, like the calculation undertaken by the devout sentencing judge, is not lawfully open to him. If the framers of the Constitution were not fools, they knew that trials would cost money. They apparently decided that the price was worth paying. ${ }^{71}$ Under our Constitution, it is simply impermissible to balance the virtues of trial against the economic costs of trial. Indeed, the Constitution may have resolved this issue more clearly than it has condemned a judicial offer of church attendance as an alternative to imprisonment, for although the framers never may have considered the effect of the first amendinent on governmental rehabilitative efforts, they surely did not overlook the fact that the sixth amendment would have an impact on government treasuries. ${ }^{72}$

67. See, e.g., Sherbert v. Verner, 374 U.S. 398 (1963).

68. U.S. CoNST. amend. VI.

69. See, eg., Alschuler, The Supreme Court, the Defense Attorney and the Guilty Plea, $47 \mathrm{U}$. CoLo. L. Rev. 2, $63-65$ (1975); Note, supra note 23, at 1398-1401.

70. Nemerson, supra note 11, at 725-29; accord, Hyman, Bargaining and Criminal Justice, 33 RutGers L. REv. 3, 20 (1980).

71. Of course, the framers of the sixth amendment may not have recognized exactly how much trials would cost almost 200 years later. If, however, the trial process has become too elaborate, too legalized, and too costly im ways that the framers of the Constitution did not intend, the solution plainly does not he in a procedure that avoids trial altogether.

72. Professor Nemerson recognized that under Supreme Court decisions "mere administrative efficiency does not justify infringement of fundamental rights." Nemerson, supra note 11, at 726 (citing Cleveland Bd. of Educ. v. LaFleur, 414 U.S. 632, 646-47 (1974); Stanley v. Illinois, 405 U.S. 645, 656-57 (1972)). He contended, however, that 
Again, however, there is a inore important point. Even if, contrary to my belief, the authors of the Constitution never inade this sensible judgment, we should want to inake it ourselves. Before imposing criminal punishment, a decent society should want to hear whatever an accused person nuight be able to say in his defense. Not only should his right to a hearing be freely given, but its exercise should be valued both for his sake and for society's. In a proceeding whose potential consequences are so grave, to discourage the accused froni presenting his defense is morally objectionable. ${ }^{73}$ The accused's right to a hearing, recognized far inore widely in the world and far longer im history than the principle of separation of church and state, should also be regarded as fundamental. It too should limit the scope of the utilitarian calculations that we are willing to undertake. To subject its merits to constant reassessment on a case-by-case basis is to diminish its value and, indeed, to call into question our basic humanity in the treatment of the people we accuse of crime.

In short, utilitarian defenses of plea bargaining place a price in dollars, and a very low one at that, on thimgs that we sliould be reluc-

[i]t is unrealistic to equate the costs of the institutional inquiries mandated by "irrebuttable presumption" and related procedural due process cases with the tremendous cost in financial and liuman resources of impaneling a jury pool, selecting a jury and alternates, and providing a courtroom, trial judge, public defender, court reporters, bailiffs, clerks, witnesses, and so on. The costs of full-blown criminal trials are not mere administrative costs.

Nemerson, supra note 11 , at 726 . One wonders, however, whether a person facing a possible jail or pemitentiary sentence should not receive at least as full a hearing as a person facing a possible 10-day suspension from a public school or the temporary loss of a stereo. See Goss v. Lopez, 419 U.S. 565 (1975); Fuentes v. Shevin, 407 U.S. 67 (1972). Plea bargaining of course results in a waiver of the right to any hearing. If, as Professor Nemerson seems to contend, society cannot afford the costs of "full-blown criminal trials" but can afford the costs of administrative hearings when students face brief suspensions from public schools, the appropriate remedy unight be to amend the Constitution to provide for less expensive or "half-blown" crimmal trials.

Indeed, Professor Nemerson's position seems to bc that the more the framers of the Constitution have given us, the less we get. If the framers had provided only for administrative hearings in criminal cases, economic concerns would be irrelevant; these concerns would offer no justification whatever for an "infringement of fundamental rights." Because the framers thought that criminal defendants deserved much more, however, economic concerns can justify a practice that is designed to avoid hearings altogether. Like the Supreme Court, Professor Nemerson seems to have things topsy-turvy.

73. Remarkably, the Supreme Court has adopted exactly this moral viewpoint in its rulings concerning a convicted defendant's right to appeal (a right whicl, unlike the right to trial, is not guaranteed by the Federal Constitution, see McKane v. Durston, 153 U.S. 684 (1894)). In North Carolina v. Pearce, 395 U.S. 711 (1969), the Court held that when a defendant who has successfully attacked his conviction on appeal is convicted after a retrial, a trial judge ordinarily cannot impose a more severe sentence than had been imposed following the defendant's first conviction. It said, "A court is 'without right to . . . put a price on an appeal. A defendant's exercise of a right of appeal must be free and unfettered ....." Id. at 724 (quoting Worcester v. Commissioner, 370 F.2d 713, 718 (1st Cir. 1966)). It is bizzare, however, to msist that the road to appeal must remain free and unfettered and then to pernit the erection of obstacles on the only access road there is. Surely a defendant's right to one hearing is more important than his right to a second hearing designed to correct possible errors in the first. 
tant to sell: human liberty, the legitimate objectives of the criminal sanction, and the right to a liearing. Even a dedicated utilitarian ought to recognize that this practice is no bargain.

A possible response to this analysis might emphasize that it is easier to describe the requisites of a proper sentence in the abstract than to find one in practice. In a particular case, there may be plausible arguments for a number of sentences of widely differing severity. When it seeins nearly impossible to tell wliere justice lies and wlien, indeed, the imposition of sentence frequently seeins largely the product of guesswork, it may appear natural for a prosecutor or trial judge to attach some weight to the fact that a particular offender has saved tlie state the burden of a trial. Froin the judge's perspective, the apparent choice may not be between just and unjust sentences but between sentences of essentially equal merit. Even if a deliberate sacrifice of penological values could not be justified for the sake of producing economic gains, perhaps a judge ought to consider tlie benefit that a guilty plea may confer upon the state in resolving his doubts in a situation of indeterminacy.

The troublesoine nature of this reasoning is suggested, lowever, by an example that imitially inay seein far-fetclied. An instructor in a financially troubled private scliool lias coinpleted his grading of a group of term papers and has found a handful that seem on the borderline between " $A$ " and "B." Even after re-reading tlie papers, the instructor remains undecided--so inuch so that lie cannot imagine a much better inethod of determining his students' grades than the flip of a coin. Because flipping a coin would be arbitrary and purposeless, however, the instructor adopts a different principle of selection. $\mathrm{He}$ awards "A's" to students who, in response to his suggestion, have agreed to contribute five liundred dollars to the school and "B's" to students who have declined to nake this contribution.

A financial contribution to the school's impoverished treasury would, we can assume, serve a valuable purpose, and the instructor argues that he should be permitted to pursue this goal in what seems to him a situation of hopeless indeterminacy. Although his argument seems to balance a tangible gain against a clioice of little consequence, most of us surely would condemn his action as improper. One reason is that this action would violate our sense of equality; we believe that students wlio liave perforined identically in the instructor's course should receive identical grades even if we do not know whetlier the grades should be "A" or "B." Moreover, we are not inclined to "balance" our perception of what equitable grading should entail against the utilitarian gains that a five-liundred-dollar contribution might provide; these "extraneous" gains are simply not what we understand 
grading to be about. Finally, despite the instructor's protests of indeterminacy, we inay not entirely believe him. We sense that his grading will indeed be fairer if he bases it "on the inerits" than if he considers extraneous factors. Even if a decision on the inerits would involve considerable guesswork, we are confident that a choice nade on this basis would approach the objectives of the grading process more closely than any alternative.

Similarly, we inay not know what constitutes a just sentence, but we do know some of its qualities. One aspect of a just sentence is that it respects the principle of equality, and, at least as an initial matter, we are offended when defendants of equal culpability are treated differently simply because they have made differing tactical decisions. Although attaching weight to these decisions inight serve soine social purpose, we sense that this purpose is not, or should not be, what sentencing is about. ${ }^{74}$ Moreover, a just sentence inust be the product of a just process-one that focuses "on the merits" rather than on extraneous social objectives. Despite protests of indeterminacy, we believe that a judge's direct consideration of the sentences that offenders deserve ultimately will produce fairer sentences than an inquiry that ranges much more widely.

\section{The Limits of Penological Rationales for Plea Bargaining}

This Article has contended that neither of the common rationales for plea bargaining articulated in Brady v. United States ${ }^{75}$ is persuasive. Even if these rationales did seen plausible in some cases, however, they plainly would become ludicrous in a case like Bordenkircher $v$. Hayes, ${ }^{76}$ which the Supreme Court decided eight years after Brady. In this case, the Court upheld the constitutionality of imposing a life sentence upon a trial defendant who almost certainly could have secured a five-year sentence had he accepted a proseeutor's offer and entered a bargained plea of guilty. This difference im treatınent could not have been justified even reinotely by the failure of the defendant to save the state the cost of a trial or by his possibly unrepentant state of inind in demanding a trial. If the concerns that the Court articulated in Brady were relevant, they suggested at most that some difference in sentence unight flow from the defendant's choice of plea, not that the plea could

74. Utilitarian defenses of plea negotiation become especially mcongruous as states revise their penal codes to imcorporate a "just deserts" model of sentencing. As Professor Louis Michael Seidman has argued, the "jnst deserts" model is plainly imcompatible with continued use of the sentencing process to achieve "broader goals such as . . processing large nuunbers of defendants quickly through the system." Seidman, Factual Guilt and the Burger Court: An Examination of Continuity and Change in Criminal Procedure, 80 ColuM. L. Rev. 436, 497-98 (1980).

75. 397 U.S. 742 (1970).

76. 434 U.S. 357 (1978). 
be many times more important than the crime in determining the extent of the defendant's punishment. In Bordenkircher, however, the Court refused to consider how far the penological rationales of Brady might be extended; it failed to consider whether, as a nratter of legitiinate sentencing policy, the sentence imposed following a trial could be $10 \%$ higher, $100 \%$ higher, or $500 \%$ higher than the sentence imposed following a plea of guilty. Moreover, it declined to employ an "elaborate, sophisticated, and sensitive approach" to individual cases like the one that the majority opimion's author, Justice Stewart, consistently had advocated in judging the pressures used to obtain out-of-court confessions. ${ }^{77}$

The Court's reluctance to face these issues was, perhaps, understandable. A ruling that the penalty imposed for one defendant's exercise of the right to trial was excessive might have plunged the Court into a review of innumerable other sentences that defendants had received after rejecting prosecutorial offers of lenient treatinent in exchange for pleas of guilty. Moreover, it would have been alinost impossible for the Court to articulate how great a sentence differential was too great. The perceived difficulty of drawing any principled line apparently led the Court to assert that Brady and other earlier cases had resolved the issue before it, and to intimate that so long as prosecutors do not threaten defendants with unlawful actions to induce their pleas, there are no constitutional limits on the inagnitude of the pressures that they can exert: "[B]y tolerating and encouraging the negotiation of pleas, this Court has necessarily accepted as constitutionally legitimate the simple reality that the prosecutor's interest at the bargaining table is to persuade the defendant to forgo his right to plead not guilty."78

77. Most notably, in 1966 Justice Stewart joined Justice Harlan's dissenting opinion in Miranda v. Arizona, 384 U.S. 436, 504 (1966) (Harlan, J., dissenting). This opinion favored a caseby-case assessment of the pressures brought to bear on particular suspects-“an elaborate, sophisticated, and sensitive approach . . . judicial' in its treatınent of one case at a time, . . . [and] flexible in its ability to respond to the endless mutations of fact presented . . ." Id. at 508 (Harlan, J., dissenting). In Bordenkircher, however, neither Justice Stewart nor any other member of the Supreme Court seemed willing to employ in guilty plea cases the flexible approach that courts had employed in confession cases hiterally for hundreds of years. See Alschuler, supra note 48 , at $12-13$.

Justice Powell did comment in Bordenkircher on the harshness of the life sentence that the defendant had received and on the harshness of the prosecutor's imitial offer as well. 434 U.S. at 369-71 (Powell, J., dissenting). He focused on the severity of the threatened penalties in the abstract, however, not on the difference in treatinent that flowed from the defendant's choice of plea. Indeed, Justice Powell and the other dissenting Justices apparently would have upheld the penalty that the defendant had incurred by exercising his right to trial if only the prosecutor had einployed some additional miceties in the timing of his threat and offer. Id. at $368 \& \mathrm{n} .2$ (Blackmun, J., dissentimg, joimed by Brennan and Marshall, J.J.); id. at 371 (Powell, J., dissenting).

78. Bordenkircher v. Hayes, 434 U.S. 357, 363-64 (1978). In upholding a sentence differential of shocking magnitude, the Bordenkircher Court may indeed have been following Brady. See Brady v. Umited States, 397 U.S. 742, 755 (1970) (quoting Shelton v. Umited States, 246 F.2d 571 
The tendency of judges and other officials to extend penological rationales for plea bargaining beyond any legitimate scope that they might have is apparent in a variety of contexts. ${ }^{79}$ None of these rationales, for example, could justify a system in which, as Professor Cook found, federal draft-law violators who have exercised the right to jury trial are sentenced twice as severely as those who have pleaded guilty. ${ }^{80}$ Indeed, the limited potential scope of penological rationales for plea bargaining may be one reason for the current shift of emphasis to the "dispute resolution" function of this practice. As this Article will indicate, justifications for plea bargaining based on the "dispute resolution" function frequently seem to authorize inuch more substantial sentence differentials. ${ }^{81}$ In any event, debate about whether a defendant's choice of plea should have some effect upon his sentence may seem artificial in light of the inanifest tendency of self-interested officials to carry an affirmative answer inuch too far and in light of the

n.2 (5th Cir. 1957), rev'd per curiam on confession of error, 356 U.S. 26 (1958)). The Court's apparent position that only a threat of unlawful action can render a bargained guilty plea involuntary is discussed in Alschuler, supra note 69, at 58-70. See also Note, Bordenkircher v. Hayes: Ignoring Prosecutorial Abuses in Plea Bargaining, 66 CALIF. L. Rev. 875 (1978).

79. Indeed, in Brady itself the Court assuned that the defendant's guilty plea had been induced by the government's threat to impose the death penalty following a trial. In this context, it is difficult to see the relevance of some hypothetical defendant's willingness "to enter the correctional system in a frame of inind that affords hope for success in rehabilitation over a shorter period of time than inight otherwise be necessary." Brady v. United States, 397 U.S. 742, 753 (1970).

Even as noted a jurist as Walter V. Schaefer was willing to probe psychological subleties under the shadow of a plea bargaining bludgeon. In People v. Darrah, 33 Ill. $2 d$ 175, 210 N.E.2d 478, cert. denied, 383 U.S. 919 (1965), he wrote:

[A] rule that would prohibit any differentiation between a sentence imposed after a plea of guilty and one inposed after a trial . . . would require a sentencing judge to ignore in every case the defendant's knowledge of his own guilt, however clearly that knowledge unight have been established, and to disregard the assumed psychological effect of an acknowledgeinent of guilt as an important step in the process of reformation. In the present state of our knowledge of human psychology it is at least doubtful that judges should be required, in every case, to disregard that assumption when imposing sentence.

$I d$. at 180,210 N.E.2d at 481 . Justice Schaefer made this observation in a case in which the following dialogue had oceurred at trial:

The Court: I am satisfied you are a professional burglar.

The Defendant: Not too professional, your honor.

The Court: Well, that is about what I was going to say. . . . As I indicated to your attorney, if you had been convicted by a jury, your sentence would have been considerably greater.

The Defendant: Ten to forty.

The Court: That's right. . . . Nevertheless, as long as you plead[ed] guilty with a sort of an understanding that your sentence would be seven to fifteen, I ain inclined to adhere to the State's Attoruey's recoininendation.

Id. at 179, 210 N.E.2d at 480-81. Even if one assumes the cogency of Justice Schaefer's argument, one wonders whether the "not too professional" burglar in Darrah was repentant and, if he was, whether his acknowledgement of guilt warranted a more than $60 \%$ reduction in his maximum sentence.

80. See text accompanying note 3 supra.

81. See text accompanying notes 83-91 infra. 
absence of any effective mechanism for limiting the scope of a guiltyplea defendant's reward. The advocates of plea bargaining have at most suggested some penological concerns that properly could affect a determination of sentence following the entry of a plea of guilty. None of these advocates has suggested a mechanism for inaking the concerns that he considers proper determinative in practice. ${ }^{82}$

II

\section{Plea Bargaining as a Form of Dispute Resolution}

Current defenses of plea bargaining tend to view the sentence differential in a different light from those that this Article has considered. The defendant who pleads guilty may often be sentenced less severely than the defendant who stands trial and is convicted, but he is obviously sentenced more severely than the defendant who stands trial and is acquitted. This result is merely what one would expect from a process of compromise, for the purpose of coinpromise is to seek a middle ground. Just as the plamtiff im a civil case im which liability is disputed cannot expect to settle the case for as much money as a jury might have awarded if liability had been established, the prosecutor im a criminal case ordimarily should not expect to obtain as severe a sentence through plea bargaining as a court might have imposed had guilt been demonstrated at trial. Moreover, like the defendant in a civil case who surrenders his chance of vindication at trial in order to obtain a limitation upon the damages that a jury might award, a criminal defendant may find it advantageous to surrender his chance of acquittal for a limitation on his sentence. In other words, the defendant abandons his chance of obtaining a sentence of zero, and the prosecutor abandons his chance of obtaining a sentence of life. An observer of this process, echoing the late entertainer Ted Lewis, might ask, "Is everybody happy?," for if the defendant and the prosecutor were not happy with the bargam, they surely would not enter it. ${ }^{83}$

82. This criticism seems especially applicable to the American Bar Association Project on Standards for Criminal Justice. While approving charge and sentence concessions for defendants whose guilty pleas have aided "in eusuring the prompt and certain apphication of correctional measures" to them, 1968 ABA STANDARDs, supra note 11 , at $\$ 1.8(\mathrm{a})(\mathrm{i})$, the Project rejected the view that "a defendant who saves the state the cost of trial should receive concessions as a result." Id. at 50. It seems unrealistic, however, to expect prosecutors and judges to engage in nice calculations of the deterrent trade-offs that may arise among certainty, proinptness, and severity and wholly to ignore their natural interest in avoiding the burdens and expenses of trial. See Alschuler, supra note 8 . The ABA offered no hint of how its proposed schene might be inade operational.

83. The view that plea bargaining embodies a "jurisprudence of joy" was once expressed by a Detroit prosecutor who had conducted all of that city's plea bargaining for a number of years:

By reducing a charge, everybody seems to be happy. The defendant and his attorney feel that they have accomplished something by being able to plead to an offense less severe than that for which there was actual guilt; the prosecutor is happy because he does not 
This approach to plea bargaining plainly regards the process primarily as a form of dispute resolution rather than as a sentencing device. Earlier defenses of plea negotiation started froin the premise that the relevant task was merely to compare two groups of defendants whose guilt was entirely clear. The inquiry was simply what punishment these two groups of defendants deserved and whether there was any principled justification for treatimg the two groups differently. Although prosecutors do view the strength or weakness of their cases as a critical factor in bargaining and therefore bring the greatest pressures to plead guilty to bear on defendants who may be innocent, ${ }^{84}$ most defenders of plea negotiation a decade or so ago seemed reluctant to admit that this practice could result in the conviction of people who would not have been convicted at trial. ${ }^{85}$ Current defenses, however, typically proceed from a different preinise: The most important characteristic of the defendant who pleads guilty is simply that it is not clear that a court or jury would find him guilty beyond a reasonable doubt. Plea bargaining is designed to compromise an unresolved dispute between the defendant and the state; and from this perspective, it is almost irrelevant what treatment the defendant might have been thought to deserve if there had been no dispute or if guilt had been authoritatively resolved through trial. The object of out-of-court settlement is not to determine the sentence that a defendant deserves but to make everybody happy. One contemporary advocate of plea bargaining, Professor H. Richard Uviller, has defended "the plea for a price" by saymg:

One might pause to consider why a society which prides itself on its commercial tradition finds the word "price" so shameful im this context. Surely im this, as in any other usage, the term denotes no more than that poimt at which the parties, taking all their common and opposing interests into account, find a inutually acceptable meeting of surrender and gain. ... [T] The discovery that criminals weigh advantages and risks im making important decisions, or that prosecutors and judges also think in "cost-benefit" terms, is not shocking. A courtroom is not, after all, a church. ${ }^{86}$

have to try the case; society is happy because the defendant, if sentenced, is put away for the same amount of time as if he had pleaded to the original charge; the courts are happy because the dockets do not become congested; the police are happy if the defendant is sentenced, but if he is not they walk alone in their unhappimess.

American Bar Foundation, LaW ENForCEMENT IN the METropolis 135 (Mcintyre ed. 1967). See also M. Rubinstein, S. Clarke \& T. White, Alaska Bans Plea Bargaining 56 (1980) ("Since everybody wins by negotiating, why fight?").

84. See Alschuler, supra note 59, at 58-64.

85. See, e.g., Note, Official Inducements to Plead Guilty: Suggested Morals for a Marketplace, 32 U. CHI. L. REv. 167, 176 (1964).

86. Uviller, Pleading Guilty: A Critique of Four Models, 41 LAW \& CONTEMP. PROB. 102, 102-03 (1977). See also R. POSNER, ECONOMIC ANALYSIS OF LAW 443 (2d cd. 1977): 
Penological rationales for plea bargaining raise the usually unanswered question of how great a reward a guilty-plea defendant should receive im our temples (or, as Professor Uviller might prefer, our countmg houses) of justice; indeed, they seem to justify only a minor discount in sentence for the defendant who pleads guilty. ${ }^{87}$ Rationales based on the consent of the parties, however, know no limits other than the parties' preferences. In my first article on plea bargaining, pubhished in 1968, I illustrated the way in which prosecutors commonly respond to weaknesses in their cases by describing several incidents like this one:

San Francisco defense attorney Benjamin M. Davis recently represented a man charged with kidnapping and forcible rape. The defendant was innocent, Davis says, and after investigating the case Davis was confident of an acquittal. The prosecutor, who seems to have shared the defense attorney's opinion on this point, offered to permit a guilty plea to sinuple battery. Conviction on this charge would not have led to a greater sentence than thirty days' iniprisonment, and there was every likelihood that the defendant would be granted probation. When Davis informed his client of this offer, he emphasized that conviction at trial seemed highly inıprobable. The defendant's reply was sinıple: "I can't take the chance." $\$ 88$

My article did not discuss this case at length because I thought at the time that it needed little analysis. Penological rationales for plea bargaining were then taken seriously, and the defendant's guilty plea certainly had not manifested his remorse for rape and kidnapping, let alone enough remorse to warrant a reduction of these charges to a misdemeanor. Moreover, I assumed that most readers, and even most defenders of plea bargaining, would share the view that a prosecutor who recognized his inability to prove a serious charge at trial ought not use that charge as leverage to obtain a ninor conviction; that it was mappropriate for a prosecutor to try to obtain some token of humiliation from every defendant; that if the defendant were guilty of two serious felonies, a thirty-day or probated sentence would be laughable, a sanction serving no purpose other than face-saving or the enhancement of a prosecutor's "batting average"; that the same sanction would be a cruel imposition if the defendant were innocent of any wrongdoing; indeed, that whatever the just result in this case might have been, that it plainly had not been achieved; and that even if the defendant had

Plea bargaining-the counterpart in criminal procedure to settlement negotiations in civil-is often criticized both as denying the defendant's right to the procedural safeguards of a trial and as leading to reduced sentences. Neither criticism is persuasive. If a settlement did not unake both parties to a criminal case better off than if they went to trial, one or the other would invoke his right to a trial.

87. See text accoinpanying notes 75-82 supra.

88. Alschuler, supra note 59, at 61 . 
nade an intelligent choice and even if an imperfect trial process also might have reached an unjust result, it was important from a social perspective at least to try to do justice-important, therefore, for someone to histen to the evidence and attempt to determine whether the defendant was guilty before he was convicted and punished.

I was naive in assuming that readers would recognize intuitively something distinct about the criminal sanction that might require greater assurance of a defendant's guilt than the compromise in this case had provided. Professor Thomas W. Church, Jr., whose paper In Defense of "Bargain Justice" offers the most thoughtful, forceful, and articulate defense that $I$ have seen of the propriety of resolving criminal disputes through compromise, used this very case to illustrate how, im his view, the criminal justice system ought to work. ${ }^{89}$ He wrote:

The problem with the case against plea bargaining from the perspective of the factually innocent defendant is that the critics seem to assume that such blameless defendants are necessarily exonerated at trial. It is a sobering fact that this is not always the case. . . . If most defendants did not face a very real chance of conviction at trial, all incentive to bargaim would be eliminated, and with it this criticism of plea bargainmg. It is therefore somewhat disingenuous to argue that the innocent defendant suffers from being offered an alternative to the high stakes of a trial. ${ }^{90}$

Moreover, Professor Church maintamed that the case agamst plea bargaining from a social perspective was no more persuasive:

A conscientious prosecutor, inindful of his responsibility to protect the public welfare, might rationally conclude that the certainty of a lower sentence might better serve the public than the risk of acquittal at trial. . . . Each party . . . trades the possibility of total victory for the certainty of avoiding total defeat. ${ }^{91}$

Professor Church's argument merits careful attention. He and other contemporary defenders of plea bargaining have focused on the significance that the consent of the parties should have in criminal litigation, an issue far more substantial than the plea bargaining issues most commonly debated ten years ago. These defenders argue that if occasional cases of corruption or mcompetence are set aside, a prosecutor's determination that settlement will serve the public interest is entitled to respect and that protection of the public cannot require the rejection of a bargain that a rational prosecutor has determined will advance the public interest. Similarly, they mamtain that a criminal defendant who wishes to settle a dispute has determined that settlement will advance his interests, and fairness to the defendant cannot require

89. Church, supra note 11 , at 515-16.

90. Id. at 516 .

91. Id. at 518 . 
the rejection of a bargain that he wants to enter. When both the pubhic's interest and the defendant's have been satisfied, who is left? Who would be helped if the settlement of criminal cases were forbidden?

\section{A. The Settlement of Criminal Cases from the Defendant's Perspective: May the Perceived Benefits Be Illusory?}

In defending the transaction in which a possibly innocent defendant exchanged his guilty plea for a dismissal of rape and kidnapping charges, Professor Church maintained that the bargaining process had given this defendant a more favorable option than he would have had in its absence. Church's argument envisioned as a baseline a "normal scheme of things" that a bargaining offer could "better" from the defendant's perspective. ${ }^{92}$ In his words, the prosecutor's offer was merely "an alternative to the high stakes of a trial." Indeed, Professor Church made his ethical premise explicit-and acknowledged its sometimes problematic character-in his discussion of sentencing. He recognized that "plea bargaining, particularly when the judge or prosecutor mampulates posttrial sentences to 'punish' those who refuse to plead guilty, can operate to coerce or unfairly encourage guilty pleas,"93 and he suggested a "reform" that, in his view was necessary to "a defensible plea bargaining system":

[T] hose cases that go to trial must be decided on the merits, without penalizing the defendant for not pleading guilty. In other words, trial sentences must be objectively deserved according to whatever sentencing philosophy is embodied in the penal code. Plea bargaining should therefore result in sentences less than this theoretically correct sentence. ${ }^{94}$

What is true of the sentencing process, however, seems true of the charging process as well. In determining whether a defendant has benefited from plea bargaining, it is necessary to consider what charges probably would have been filed agamst him in the absence of this practice. In the case of the possibly innocent defendant, the prosecutor apparently did have some chance of obtaining a conviction at trial on the rape and kidnapping charges; as Professor Church argued, the charges could not have prompted a plea of guilty unless the defendant sensed that this possibility existed. Nevertheless, the prosecutor apparently recognized that the likelihood of a felony conviction at trial was small-hence his exceptionally favorable (or exceptionally coercive) offer. On Professor Church's ethical assumptions, a critical question is

92. See also Brunk, The Problem of Voluntariness and Coercion in the Negotiated Plea, 13 LAW \& Soc'Y REv. 527 (1979).

93. Church, supra note 11 , at 519 .

94. Id. at 520 . 
whether the prosecutor would have pursued the rape and kidnapping charges in a criminal justice system without plea bargaining.

Of course one can never know the answer to this question (which is only to say that the ethical scheine envisioned by Professor Church could never be administered). Nevertheless, if the defendant were not a special "target" of law enforcement officers, it does not seein too naive to suppose that a prosecutor in a no-plea-bargaming system would have declined to devote substantial resources to a case in which there was only an outside chance of conviction at trial. In the absence of plea bargaining, the defendant in this case inight never have been charged even with a misdemeanor, and in that event, the defendant plainly would not have profited froin the existence of plea bargaining. Instead he would have suffered because our current criminal justice system encourages prosecutors to file dubious charges-and even to pursue them when necessary-in the hope that these charges will lead defendants to plead guilty to relatively ininor offenses. Although the defendant in this case inay have chosen the lesser of the evils that the bargaining process left open to him, a prohibition of plea negotiation might have changed the gameboard so substantially that he could have avoided both branches of the dilemma. A restriction of plea bargaining would encourage prosecutorial decisionmaking "on the merits," and although this kind of decisionmaking does not always work to the benefit of defendants, soinetimes it does.

Professor Church, a sensitive and thoughtful observer aware of the impropriety of using plea bargaining to make a defendant's "normal" position worse, seems not to have considered this possibihty; apparently even a careful and well-mtentioned observer can shp imto an unwitting defense of transactions in which the benefit to defendants is illusory. Indeed, advocates of plea bargaining often seem to assume that, $\mathrm{im}$ the absence of this practice, every defendant would be treated in the saine inamrer as defendants who currently exercise the right to trial. As Professor Church recognized in his discussion of sentencing, however, this assumption is unwarranted. The appropriate baseline from which to measure the benefits the plea bargaining may afford to defendants is difficult to perceive. It certainly is not the treatment that trial defendants currently receive in a systein whose decisions and processes are shaped by the desire of prosecutors and judges for guilty pleas.

When bargaining decisions are inade by busy crimimal justice practitioners with little time for reflection and with stronger immediate interests than criminal justice scholars, the danger of self-serving rationalization seems great. The sentencing issue that Professor Church addressed inay illustrate this danger. Altlough prosecutors commonly 
offer extraordinary sentencing concessions when they fear defeat at trial, both prosecutors and judges are naturally reluctant to approve what Professor Church called "less than theoretically correct" sentences for obviously guilty defendants. The interests of these officials may lead thein to do what Professor Church said that they should not do-_manipulate posttrial sentences to 'punish' those who refuse to plead guilty." Nevertheless, prosecutors and judges are unlikely to concede or even to recognize that the exigencies of a bargaining system have led them to approve excessive punishments. If asked, they almost certainly would insist that trial defendants were sentenced only as severely as they deserved. The prosecutors and judges might mean, however, only that they do not regard the sentences imposed after trial as "theoretically indefensible" or as "inherently unjust." Their denial of unfairness might not inean that they would have approved the same sentences in a regime without plea bargaining or that they would not have regarded other sentences as even inore appropriate. It is difficult to estimate what one would have done in a system different from the system that one knows, and it is difficult to determine what effect a different systen 1 of criminal procedure ultimately might have on substantive attitudes toward sentencing. ${ }^{95}$ For these reasons, it is difficult to tell whether defendants truly benefit from plea bargaining in terms of conviction and sentencing outcomes. Although any judgnient on this issue would be speculative, an Appendix to this Article exannines some empirical evidence that seems to bear on the question. ${ }^{96}$

\section{B. The Settlement of Criminal Cases from an Operational Perspective}

Like many other observers, Professor Church suggested that the critics of plea bargaining can be divided into hawks, who maintain that bargaining results in unwarranted leniency, and doves, who contend that this practice burdens the right to trial. ${ }^{97}$ This view misses the thrust of the criticisin that $I$, at least, have advanced in several lengthy articles. As I have indicated, I do support the "dovish" position and, on occasion, the "hawkish" position as well. One could sense an incompatibility between these two positions only if one viewed criminal justice inerely as a contest and always cheered for the defendant or the

95. If, for example, a prohibition of plea bargaining did result in a more frequent imposition of severe sentences, at least the possible injustice of these sentences would become more visible than it is when the same sentences are limited to a small number of defendants convicted at trial. This enhanced visibility (or the expenses resulting froin a substantially increased prison population) might lead to sentencing reform that would benefit all defendants, not simply those who waive the right to trial.

96. Appendix B infra.

97. Church, supra note 11, at 510. See also Bashara \& Gardner, Plea Bargaining: A Useful Tool in the Criminal Justice Process, in CRIMINAL Justice Issues: Prompt TRIAL (Citizens Research Council of Michigan 1978). 
state-or, perhaps, if one viewed all criminal justice issues in terns of some metaphorical pendulum that might swing too far toward either defense or prosecution interests. ${ }^{98}$ Nevertheless, the basic criticisin that iny earhier writings have developed seeins to fit neither branch of Professor Church's typology. Whatever the theoretical justification for a system of plea bargaining, I have argued that any operational system frequently will be bent to serve the personal and organizational interests of the lawyers and judges who administer it. In iny view, the central problem of our current criminal justice system does not lie in redressing some imbalance in a zero-suin gaine or in swinging soine mythical penduluin toward a center point; it lies in insuring that the interests of both defendants and the state are not subordinated to the interests of criminal justice administrators. Plea bargaining as it works in fact is not simply a process by which "the parties, taking all their common and opposing interests into account, find a inutually acceptable ineeting of surrender and gain"; pretty pictures of well-informed parties striking a rational balance of litigation risks iniss an important part of what invariably happens when a systein of plea bargaining inoves from abstraction to reality.

This Article is not the place for an extensive review of my earlier writings. In brief and at the risk of overeinphasizing some aspects of a coinplex and variable process, these articles have described trial judges who "look for guilty pleas the way that salesmen look for orders" and who commonly greet each other with the inquiry, "How are your dispositions this inonth?"99 They have described prosecutors whose desire to "inove" cases, to maintain high "batting averages," to keep desirable job assignments, to please influential defense attorneys, and to avoid the wrath of trial judges soinetimes leads to inuch inore generous offers than a rational vectoring of litigation risks could warrant. ${ }^{100}$ The articles also have described overburdened public defenders whose all but instinctive response to inost cases is the guilty plea-and unscrupulous private defense attorneys who handle large volumes of cases for lessthan-spectacular fees, who plead virtually all of their chents guilty, and who soinetimes even deceive their clients for the sake of turning a "fast buck."101 Finally, the articles have described inore virtuous (and hopefully inore numerous) private defense attorneys who seriously try to do their best for each client but whose judginent is influenced by the pressures of their office caseloads, by the fact that they have pocketed their fees in advance, and by the recognition that a guilty plea saves days of

98. See Professor Herbert L. Packer's influential but seriously inisleading paper, Two Models of the Criminal Process, in H. PACKer, The Limirs of the Criminal Sanction 149-73 (1968).

99. See Alschuler, supra note 7, at 1114.

100. See Alschuler, supra note 59, at 105-12.

101. See Alschuler, supra note 8 , at 1206-70. 
work. ${ }^{102}$

Of course, my writings have not denied that bargaining lawyers and judges usually do consider the merits of individual cases in striking plea agreements; they have not denied that plea bargaining frequently achieves "rough justice" in an expeditious fashion; they have not even contended that the interests of lawyers and judges are currently more important to the outcome of criminal cases than the merits. My thesis has been simply that the interests of criminal justice administrators are more influential than they should be and more influential than they need to be. The factual assumption underlying most current defenses of plea bargaining - that defense attorneys are nearly perfect surrogates for their clients and prosecutors nearly perfect surrogates for the public interest-is to a considerable extent inaccurate. ${ }^{103}$

Professor Church adverted briefly to this difficulty but concluded, "The incentive to reduce conflict among regular systein participants exists equally at trial . ..."104 For a professional political scientist to advance this argument is surprising, for the argument seems to deny that institutional arrangements can make a difference. ${ }^{105}$ A casual, unstructured, closed-door procedure that depends to a notable extent on personal relationships is surely different, at least in degree, from an open, formalized procedure that has been designed im part to minimize the likelihood of favoritism, personal influence, and hasty or casual judgment.

The American criminal trial is, of course, an adversary procedure

102. See id. at 1199-206.

103. In attending academic conferences on plea bargaining, $I$ have been struck by the extent to which people who should understand this subject (and who, indeed, have written books about it) sound like the blind men describing the elephant. One scholar may begin by declaring that plea bargaining usually produces the same result as trial. When two experienced lawyers can use their expertise to predict the probable outcome of a trial, they are very likely to agree; and once this happens, there is no longer any need for the trial to be held. Another scholar theu suggests that trial is often a capricious process whose results cannot be predicted. When a case goes to trial, one either "wins big" or "loses big." The goal of plea bargaining is not to produce the same result as trial but to "vector" the risks of litigation and to reach a more sensible middle ground. Still another academic then contends that the object of plea bargaining is neither to produce the same results as trial nor to vector the risks of litigation. The goal is to escape altogether the irrationahties of an overly legalized trial system and to "settle the facts" or to achieve "substantive justice" without regard to technicalities. Then an older lawyer who has bargamed more guilty pleas than everyone else in the room proclaims that all of this misses the point. A lawyer's object in plea bargaining is to take as inuch as possible from the other side by threat, bluster, charm, bluff, campaign contributions, personal appeals, friendship, or whatever else works. Finally some cynic (usually me) says that sometimes the dominant motivation is for lazy lawyers and judges to take the money and go home early. Of course, to some extent, all of these things are happening at the same time. The disagreement, if not wholly illusory, merely concerns the relative size of the trunk, tail, legs, ears, and side.

104. Church, supra note 11, at 521; accord, Hyman, supra note 70, at 14.

105. This fatalistic attitude is in fact extremely common among practitioners. See, e.g., M. Rubinstein, S. Clarke \& T. White, supra note 83, at 17. 
with all of the virtues and defects that this term implies. ${ }^{106}$ Although no procedure can insure a constant identity of interest between a representative and the person whoin he is to represent, one virtue of an adversary systein is that it does tend to proinote this identity of interest. The success of an advocate in an adversary systein depends largely on how well he advances the interests that he has been assigned to serve. The advocate's performance is visible and subject to review by the people who pay for it, by people who may pay for a similar service in the future or who inay otherwise further the advocate's professional goals, and by detached professional observers whose esteem may seem important in itself and who may even be empowered to sanction the advocate's performance if it falls below expected levels of competence.

It is not only the visibility of the trial process, moreover, that encourages genuine advocacy. The forms and procedures of this process establish tasks that an advocate is expected to perform, and they imdicate standards that he can be expected to meet. Most importantly, they seein likely to affect his basic concept of his role. Adversary procedures encourage a representative to view himself, not as a judge or administrator, but truly as an advocate. They encourage him to prepare thoroughly, to argue vigorously, and to insure that evidence bikely to advance his chent's cause is presented and considered. A prosecutor or defense attorney whose primary concern is to cut corners probably would find a regime of plea bargaining ideally suited to his goals. This advocate miglit not develop a stellar reputation even im this system, but he could survive - and some do-simply by saying, "What do you think the Bobby Johnson case is worth? O.K., I'll see if he'll take it."107 Cutting corners surely would be inore difficult in a systein in which no apparent reward flowed froin a defendant's decision to waive the right to trial. In sliort, the problein of guaranteeing an identity of interest between disputants and their surrogates is presented by botll adjudicative and settleinent procedures, but not to the same extent. The necessity of presentimg a dispute to a dismterested third party is likely both to affect the surrogates' attitudes and to constrain their ability to advance interests other than those that they have been hired or assigned to serve.

The concluding sections of this Article will accept the apparent premise of Professor Church and others that plea bargaining involves primarily a rational adjustment of hitigation risks. After a very brief look at a constitutional issue, the Article will consider the propriety of compromising criminal cases from a long-range social perspective. Before embarking on this discussion, however, it seems important at

106. See M. Frankel, PARTiSAn Justice (1980).

107. See Alschuler, supra note 7, at 1130. 
least to advert to a reality that seems more complex than many current defenders of plea bargaining tend to make it and to note that, even on their ethical assumptions, both the current system of plea bargaining and any operational alternative might reasonably be condemned. The articulation of one possibly legitimate purpose that a system of compromise can serve should not obscure ways in whicli the same system can be abused, and the fact that any system can be abused should not obscure the fact that some systems lend themselves to abuse much more than others. The flexibility often praised by the defenders of plea bargaining encourages, not only a rational adjustment of litigation risks, but also the introduction of thoroughly improper, even corrupt considerations that they would not for a moment defend. One important fact is that many people are lazy, and bargaining makes it easy for them to split the difference without the careful analysis of litigation risks that is the touchstone of current defenses of this practice. Most people also like to be liked and to enjoy comfortable relationships with co-workers, and this factor, too, interferes with the rational analysis of eacli party's interests that is seen as the basic justification of compromise.

\section{The Settlement of Criminal Cases from a Constitutional Perspective}

In 1969 in Scott v. United States, ${ }^{108}$ Chief Judge David L. Bazelon of the United States Court of Appeals for the District of Columbia Circuit offered an early defense of the constitutional propriety of compromising criminal disputes. He wrote at a time when other advocates of plea bargaining seemed largely to ignore the extent to which prosecutors respond to the prospect of defeat at trial by magmifymg the inducements for a plea of guilty. These other advocates argued that plea bargaining merely resulted in the expeditious disposition of open-andshut cases, conserving scarce resources for legitimate disputes and preventing jurors and other participants in the criminal justice system from becoming jaded by a lengthy procession of cases $i m$ which guilt was entirely obvious. ${ }^{109}$ Judge Bazelon's concept of the legitimate function of plea bargaining, however, was exactly the opposite of theirs. In a case in which neither the prosecutor nor the defendant can confidently predict the outcome of a trial, he argued, each side has an interest in limiting the inherent risks of trial. Although a defendant who insists upon a trial and is convicted might seem superficially to have paid a price for the exercise of his riglit-a longer sentence than

108. 419 F.2d 264 (D.C. Cir. 1969).

109. See Enker, supra note 37, at 112. For inore recent expressions of the same viewpoint, see A. Rosett \& D. Cressey, Justice by Consent: Plea Bargains in the American Courthouse 165 (1976); Welaj, Guilty Pleas, 2 CrIM. JUST. Q. 24 (1974). 
he would have received had he pleaded guilty - a bargain struck solely to minimize apparent litigation risks would not in fact raise the "constitutional question of whether the right to trial could be inade costly": ${ }^{110}$

After the fact, the defendant who pleads innocent and is convicted receives a heavier sentence. But, by the same token, the defendant who pleads innocent and is acquitted receives no sentence. To the extent that the bargain struck reflects only the uncertainty of conviction before trial, the "expected sentence before trial"-length of sentence discounted by probability of conviction-is the same for those who decide to plead guilty and those who hope for acquittal but risk conviction by going to trial.

....

... The argument that the defendant who receives a heavier sentence after trial has "paid a price" . . . errs on two counts: (1) the coinparison is made at the wrong time-after trial, when the uncertainty of litigation has passed, rather than before trial-and (2) the comparison is made between the wrong categories of defendants-the class of defendants convicted after trial versus the class of defendants who plead guilty . . . rather than the class of defendants who exercise their right to trial versus the class of defendants who do not.

The situation is quite different when the prosecutor engages in bargaining not because he is willing to take a sure half loaf rather than to await the outcoine of a trial, but because his limited resources convince him he must deter defendants from demanding a trial. ${ }^{111}$

Judge Bazelon's argument has striking implications. Under his view of the Constitution, it apparently would be improper for a prosecutor to offer any concession whatever in a case in which conviction at trial seemed a certainty. Nevertheless, it would be entirely appropriate for the prosecutor to propose a thirty-day sentence in a serious rape and kidnapping prosecution in which he perceived no more than a one or two percent chance of conviction at trial. So long as the apparent costs and benefits of demanding a trial remained in equipoise from the defendant's perspective, this offer would not burden his exercise of the right to trial. One may reasonably sense something strange in this position. If somehow it were possible to have one purified form of plea bargaining to the exclusion of another, inost observers probably would prefer the form that eliminated froin the trial process the cases in which trial would serve no apparent purpose rather than the form that left for trial the cases in which there was nothing to try.

Although Judge Bazelon's argument has not escaped criticism, ${ }^{112}$ most of this criticism has focused on an issue that Judge Bazelon

110. 419 F.2d at 276 (Bazelon, C.J.).

111. Id. at 276-77.

112. See Westen \& Westin, supra note 11, at 493-94; Note, supra note 23, at 1401-02. 
largely conceded, the unworkability of his proposal in an operational system of plea bargaining. ${ }^{113}$ There is, however, a more basic objection-that the argument seriously misconstrues the Constitution. Indeed, one wonders whether Judge Bazelon would employ the same approach in evaluating the waiver of other constitutional rights. A governmental body might, for example, discourage the exercise of first amendinent rights either by paying people not to speak or by charging thein a fee for speaking. ${ }^{114}$ Would this action be permissible so long as the government neither paid more nor charged more than unost citizens thought the right to speak was worth? Contrary to Judge Bazelon's opmion in Scott, no legal principle permits the burdening of constitutional rights up to the poimt at which people are as likely to waive them as to exercise them. Instead, constitutional rights were meant to be exercised. The relevant legal principle is simply that, in the absence of a legitimate reason, the government may not burden the exercise of constitutional rights at all. ${ }^{115}$

\section{The Settlement of Criminal Cases from a Jurisprudential Perspective}

\section{The Issue in Context: Some Reflections on Contractual Freedom}

Justice Holmes once observed, "Pretty unuch all law consists in forbidding men to do some things that they want to do, and contract is no more exempt from the law than other acts." 116 Nevertheless, the view that choice should belong to the parties most significantly affected by its exercise is widely shared, and it is this basic concept of autonomy that modern defenders of plea bargaining invoke im proclaiming the

113. Judge Bazelon observed:

The divide between the two situations may be difficult to locate for even the best-intentioned prosecutor, and even inore difficult for a trial judge to review. . . . The nature of the process inay well prevent judges from actually reviewing specific instances of prosecutorial discretion in all but the most exceptional cases.

Scott v. United States, 419 F.2d 264, 277 (D.C. Cir. 1969).

114. If the right to speak were regarded as an appropriate subject for a inarket transaction, it might not matter in terms of the ultimate impact on the exercise of this right whether people were required to purchase the right from the government or instead were granted the right and empowered to sell it back. This perception is what economists call the Coase theorem. See Coase, The Problem of Social Cost, 3 J. LAw \& EcoN. 1 (1960).

115. See, e.g., Sherbert v. Verner, 374 U.S. 398 (1963). And of course, the legitimacy of a governmental reason for discouraging the exercise of a constitutional right cannot be judged in the abstract, for this approach would permit a reassessinent of the constitutional judgment that the right should be afforded. Although mcreasing government revenue is ordmarily a legitimate objective, for example, it probably would be imappropriate to balance the virtues of greater revenue against the sacrifice of first amendinent values resulting from a tax on speaking (at least a tax not directly related to costs incurred by the government by virtue of the speech). The legitimacy of the government's purpose must always be evaluated in terms of the objectives of the Constitution itself. See text accompanying notes 65-72 supra.

116. Adkins v. Children's Hospital, 261 U.S. 525, 568 (1923) (Holmes, J., dissenting). 
unorality of coinpromise. They suggest that if the parties to a criminal case can reach agreennent between theinselves, it should not be the function of any "stranger" to insist on a more objective resolution of the controversy. When only the interests of the parties are at stake, it is pointless and indeed unjust to upset any settlement that the parties have found satisfactory. In the words of an influential nineteenth-century economist who was no particular friend of inarket transactions, these observers apparently view the rushed huddles in which rights and liberty are traded each day throughout America as an "Eden of the innate rights of inan [where] alone rule Freedoin, Equality, Property and Benthain."117

As important as the concept of contractual autonomy is in our society, it has not been extended as far as some desire-most especially, not as far as Professor Richard A. Posner, the intellectual patriarch of many who view economic analysis as the inost prounising approach to the resolution of legal issues, would extend it. Professor Posner has proposed the legitimation of contract penalty clauses, ${ }^{118}$ and perhaps more strikingly, lie lias advocated the establishment of open markets im babies and body parts. ${ }^{119}$ Professor Posner has written, "The economist recognizes no limitations on [contractual] liberty other than those of incapacity, fraud, duress, inonopoly, and externality."120

The limitation most obviously omitted from Professor Posner's list is paternalisin. ${ }^{121}$ When society prevents even well-informed people from purchasing heroin and froin hiring untrained and unlicensed practitioners to treat their illnesses and to represent them im court, it restricts their freedom in ways that Professor Posner apparently considers inappropriate. Quite apart froin the issue of paternalisin, however, Professor Posner's formulation inay be unsatisfactory. Although it might not be difficult to accept his formulation if its limiting conceptsespecially "externality" - were broadly defined, sufficiently expansive definitions might deprive these concepts of any useful meaning.

Of course Professor Posner would refuse to uphold a "inurder for hire" contract, for this contract would be likely to have a fatal "external

117. I K. MARX, CAPITAL 176 (International Publishers ed. 1967).

118. Posner, supra note 48 , at 138.

119. Id. at 138-39. See Landes \& Posner, The Economics of the Baby Shortage, 7 J. LEoAl STUD. 323 (1978). Although Professor Posner's proposal for an open market in body parts was addressed primarily to the situation in which a potential purchaser sought a kidney or other organ for medical purposes, Posner indicated in another context that he would permit sadists to purchase the satisfaction of their desires from people who value money more than their dignity or their limbs. Posner, supra note 50, at 131-32.

120. Posner, supra note 50, at 138 .

121. Some of the limitations that Professor Posner would recognize-most notably "incapacity"--are, of course, paternalistic, but Professor Posner would confine paternalism to a much narrower scope than current contract law. 
impact" on a noncontracting party. Yet apparently he does not regard either the abhorrence with which noncontracting parties may view the sale of infants or the long-range attitudinal effects of these sales as the kind of externality that should limit contractual autonomy. To "count" these interests as "externalities" would of course beg the issue of contractual freedoin, for as Professor Posner lias recognized, similar "externalities" could be discovered with regard to every transaction that a substantial number of people do not like. ${ }^{122}$

With concepts like duress and externality confined as closely as Professor Posner apparently would confine them, however, his formulation may not capture even the nonpaternalistic limitations on contractual freedoin that a decent society should recognize. Most of us surely sense that "external" interests need not be disregarded entirely when they are long-range, intangible, or difficult to articulate. Indeed, as the emotional controversy over such issues as eugemics and the "right to die" deinonstrate, values at the core of the social order often seem to fit this description. If attaching weight to these values would ultimately beg the issue and blur the line between "self-regarding" and "other regarding" conduct, ${ }^{123}$ perhaps the issue should be begged, and perhaps the line that Professor Posner wislies to draw is inherently indistinct. For exainple, one inay syınpathize with John Stuart Mill, whose usually cogent analysis seemed to founder when he confronted the question whether a person should be allowed to sell himself into slavery. Mill, perhaps as strong a champion of individual autonomy as the world had seen before Posner, declared, "The primciple of freedoin cannot require that [a person] should be free not to be free. It is not freedom to be allowed to alienate [one's] freedoin." 124

122. See A. Kronman \& R. Posner, The Economics of Contract Law 258-59 (1979).

Although the following discussion will focus primarily on the question of "externality," other limiting principles accepted by Professor Posner may bear on the propriety of plea bargaining. Particularly when one recognizes that severe criminal cliarges may be filed and severe post-trial sentences imposed for the very purpose of inducing pleas of guilty, the dangers of "duress" and "monopoly" also seem apparent.

123. See id. at 258.

124. J. Mill, Utilitarianism, Liberty and Representative Government 213 (A.D. Lindsay ed. 1951).

Karl Marx noted that the ideology of the inarketplace required that laborers and capitalists be regarded as equals, and he said:

The continuance of this relation denands that the owner of the labour-power should sell it only for a definite period, for if he were to sell it rump and stump, once for all, he would be selling himself, converting himself from a free man into a slave, from an owner of a commodity into a commodity. He must constantly look upon his labour-power as his own property, his own commodity, and this lie can only do by placing it at the disposal of the buyer temporarily, for a definite period of time. By this means alone can lie avoid renouncing his rights of ownership over it.

$1 \mathrm{~K}$. MARX, supra note 117, at 168 . For more recent discussions of contracts of self-enslavement, see A. KRONMAN \& R. POSNER, supra note 122, at 256-60; G. TUllOCK, THE LOGIC OF THE LAW 
Contract of course is always a device by which people restrict their future actions. If one would uphold any contract in any situation, he 1nust beheve that it is freedom to be allowed to alienate one's freedom, at least up to a point. If the preservation of future autonomy were truly more important than the realization of present desire, all contracts would be forbidden; and although Mill certamly did not mtend this result, his formulation offered no useful distimction between the restrictions of future autonomy that he would approve and those that he would condemn. One may be impatient with this hiteralistic criticism, however, for one senses what Mill almost certainly meant-that total alienations of freedom are abhorrent, that they are inconsistent with an ideal of freedom that society should strive to perserve, and imdeed that it may be impossible to say very much more about the issue. Our revulsion at slavery runs so deep that, in some hard-to-define way, it would diminish all of us to tolerate this practice. ${ }^{125}$

Defenders of plea bargaining sometimes ask how it can advance a defendant's interest to forbid him from entering a bargam that he wants to enter, yet the same question might be asked with equal force regarding many situations im which restrictions of contractual autonomy are widely accepted. Apart from the classic conundrum of selfenslavement addressed by Jolm Stuart Mill, the contractual dilemma extends, for example, through the area of unconstitutional conditions. When a criminal defendant has accepted a sentence of ten years of church attendance rather than ten years' imprisomnent, ${ }^{126}$ he certaimly has made a sensible assessment of his self-mterest. How would it advance this defendant's welfare to prohibit the bargam? Whose interests, exactly, would the prohibition serve? Should a person not be permitted to make an intelligent waiver of his first amendment riglits? Similarly, when a person has accepted money or a job im exchange for a waiver of his right to speak on street corners, he must have determmed that the money or the job would serve him better than the right. Would it advance his mterests to prohibit a transaction that he wants to enter? It is merely a tautology that the concept of inalienable rights upon which our nation was founded is at war with an expansive concept of contractual autonomy. ${ }^{127}$

53-54 (1971); Dworkin, Paternalism, in MoRality ANd The LAw 117-18 (R. Wasserstrom ed. 1971).

125. So far as I am aware, Professor Posner has not taken a firm position on the propriety of contracts of self-enslavement. He has, however, referred to the legal prohibition of voluntary indentured servitnde as an "avoidable difficulty," Posner, supra note 50, at 125 n.70, and he and a coauthor have expressed considerable skepticism abont the standard arguments for forbidding slavery by consent. A. KRONMAN \& R. POSNER, supra note 12, at 256-60.

126. See text accompanying note 64 supra.

127. Cf. Posner, supra note 50, at 140 ("the wealth-ınaximization principle affords no basis for a refusal to trade off liberty against prosperity"). 
There seems to be no direct and satisfying answer to the a fortiori logic of the old right-privilege distinction that for a time blocked the development of today's concept of unconstitutional conditions. ${ }^{128}$ As Justice Holmes, perhaps forgetting that the life of the law has not been logic, once observed, "Even in the law the whole generally includes its parts. If the State may prohibit, it may prohibit with the privilege of avoiding the prohibition in a certain way." 129 When a person has agreed to a curtailment of his first amendment rights in order to become a pohice officer, he may indeed be "better off" than if the "privilege" of government employment had never been extended. ${ }^{130}$ If the older logic has not been answered, however, it gradually has yielded to a gentler doctrine. The reason may he in our sense that the long-range effect of a series of apparently voluntary transactions, each apparently "value maximizing" when viewed individually, would be the creation of a society in which values that most of us hold dear would mean less than they should, a society in which we might not especially want to hive. ${ }^{131}$ In that sense, "externality" broadly conceived in terms of social aspirations may best explain the doctrine of unconstitutional conditions and, perhaps, the prohibition of contracts of self-enslavement as well. ${ }^{132}$

One especially striking illustration of a paradoxical but generally accepted restriction of contractual freedom is provided by the transaction that blackmail statutes condemn. A person possessed of damaging information about another ordinarily may reveal this information or not as he sees fit. The blackmail "victim" is naturally interested in how the "blackmailer" will exercise his lawful option. The immediate con-

128. For a discussion of the right-privilege distinction of the late nineteenth and early twentieth centuries, and for a suggestion that this distinction largely supplanted a doctrine of unconstitutional conditions that the Supreme Court had articulated earher, see Alschuler, supra note 69, at 59-63.

129. Western Union Tel. Co. v. Kansas, 216 U.S. 1, 53 (1910) (Holmes, J., dissenting).

130. See McAuhffe v. Mayor of New Bedford, 155 Mass. 216, 29 N.E. 517 (1892) (Holmes, J.).

131. In Frost \& Frost Trucking Co. v. Railroad Comm'n, 271 U.S. 583, 594 (1926), Justice Sutherland wrote for the Court: "If the state nuay coinpel a surrender of one constitutional right as a condition of its favor, it may, in like manner, compel a surrender of all. It is inconceivable that guarantees enibedded in the Constitution of the United States may thus be inanipulated out of existence."

132. As Kronman and Posner have observed, the more obvious paternalistic argument for prohibiting these contracts-that only a person who was nuisinformed or insane would enter oneseems unpersuasive. A parent, for example, might incur the burdens of slavery in order to obtain food for his children or money to finance their educations. A. KRONMAN \& R. POSNER, supra note 122, at 257-58. At the same time, paternalisin and a concern for social values do tend to overlap. See Nagel, The Enforcement of Morals, Humanist, May-June 1968, at 20, 26-27. The difficulty of deterinining which motivation is dommant certainly offers no justification for disregarding long-range externalities. It inerely suggests that a rigorous opposition to paternahism usually does not take one very far. 
sequence of prohibiting a blackmail transaction may often be a dissemmation of information that the victim finds more harmful than the blackmail, and the victmi might therefore argue, "I really want to pay this person the ten dollars and to keep my misbehavior quiet. This arrangement is one that both sides find advantageous. It plainly does not protect my imterests to prohibit the agreement." Nevertheless, both our sense of long-range social interests and our more paternalistic sense that there are bimds in which human beings should not be placed have led us to reject this "value maximizing" logic.

One reason for rejecting the argument in favor of legalizing blackmail is similar to a reason why normative economic analysis often seeins unconvincing in practice: The arguinent asks us to tolerate a practice that we intuitively regard as unjust by predicting that an effort directly to suppress the injustice by outlawing a transaction that both parties find desirable would inake inatters worse-that this effort to alleviate suffering would, in fact, be likely to injure the people whom we apparently seek to benefit. This kind of argument inay sometimes be persuasive. As Professor Posner has argued, only a fanatic bases action exclusively upon intuitions of injustice, viewing the action inerely as an expression of concern and refusing to consider the action's consequences. ${ }^{133}$ Nevertheless, the toleration of injustice does not coine easily. It diminishes our sense of decency in human relationships and our sense of power over the conditions of human existence. It is therefore appropriate to view dismal consequential arguments witli skepticism, to evaluate them with care, and to consider whether they may ainount merely to rationalizations of self-indulgence.

When blackmail transactions are forbidden, a holder of damaging information may reveal it and cause greater injury to his "victim" than the victim otherwise would have experienced; but he may not. Indeed, he inay not go to the trouble of collecting damaging mformation at all. ${ }^{134}$ Similarly, when a person in a war-torn country with no soup kettles or welfare checks on the horizon is prevented from selling himself into slavery, ${ }^{135}$ the consequence nay be his starvation. Nevertheless, when the rich cannot buy slaves, they are likely to devise other advantageous bargains. They still may find it advantageous to keep the poor in pottage. The dilemma of starvation or slavery may be merely the product of unlimited contractual "freedoin" and may disappear when this freedoin is restricted. Moreover, when the state cannot make a waiver of first amendment rigits a condition of employinent, it prob-

133. Posner, supra note 50, at 118.

134. See D. Ginsburg, Blackmail: An Economic Analysis of the Law (Nov. 4, 1979) (unpublished draft).

135. Compare Batsakis v. Demotsis, 226 S.W.2d 673 (Tex. Civ. App. 1949). 
ably will not cease its hiring of police officers. People who would have sold their rights in a situation of unrestricted bargaining may keep them and obtain governmental employment as well. ${ }^{136} \mathrm{~A}$ restriction of contractual freedom should be regarded, not as automatically forcing a party to choose one branch of a dilemma, but as an effort to eliminate the dilemma entirely. And when prosecutors and otleer criminal justice officials cannot demand guilty pleas as a condition of their favor, they inay be far inore likely to extend equitable concessions on the inerits. Our horizons should not be confined to the alternatives that naturally arise in situations of unrestricted bargaining. Even when contracting parties retain the "lawful option" of defeating our goals, restrictions of contractual autonomy need not automatically be futile.

Admittedly, this analysis is mcomplete. It suggests that consequential arguments im favor of yielding to mjustice sliould not be readily accepted, but it does not identify the source of our initial perceptions of unfairness. It offers no line between the binds in whicls most of us believe that human bemgs sliould not be placed and those that we accept as tolerable and even desirable attributes of contractual autonomy.

And, alas, this Article will offer no general theory of contractual freedom. Recent attempts to distinguisl in general terms between appropriate and inappropriate contractual constramts do not seem satisfactory, ${ }^{137}$ but I can do no better. In the end, as I have suggested, some issues probably sliould be begged, and contractual freedom may be one of these issues. Our intuitions may quickly outrun analysis. ${ }^{138}$ Indeed, as reluctant as one may be to reacli this conclusion, conundrums like voluntariness, paternalism, and externality may not yield to rational fornulas. If so, the imtuitions supporting a prohibition of blackmail, of contracts of self-enslavement, and of an open market in constitutional rights seem powerful enough that one might prefer them to Professor Posner's value-maximizing logic. ${ }^{139}$

136. Indeed, in defiance of the logic of a perfect market, police officers probably would not receive even a dime less in salary if they were prevented from conferring this additional "benefit" upon their employers.

137. Brunk, supra note 92, at 532-35; Nozick, Coercion, in Phllosophy, Sciences, AND Method 440 (Morgenbesser, Suppes \& White elds. 1969).

138. I believe that Justice Holmes once referred to "an intuition of experience that outruns analysis," but I cannot recall where. Compare O. Holmes, The COMMON LAw 1 (Boston 1881).

139. An earlier draft of this Article suggested that Professor Posner's apparently unqualified approval of contract penalty clauses might extend even to the infamous penalty clause of Sliakespeare's Merchant of Venice - one that promised a pound of fiesh to the nondefaulting party. It also asked whether there were no social taboos that might lead Professor Posner's followers to disapprove transactions between willing buyers and willing sellers without tangible external effects. As an extreme case to test their convictions, the draft suggested (with apologies that were probably imadequate) a grisly situation in which a woman attempted to sell an aborted fetus for purposes of cannibalism. When one of Professor Posner's colleagues showed this draft to him, he 


\section{Fortunately, this Article need not end on so religious a note.}

responded with a number of criticisms and suggestions that were consistently thoughtful and helpful-much better criticisms than I probably deserved in view of the intemperate tone of my criticism of his work. Professor Posner also made clear that he would not extend contractual freedom to the point of upholding these two transactions.

Professor Posner earlier lrad characterized the "pouud of flesli" penalty clause as an "apparently efficient transaction . . . forbidden in the name of morality." R. POSNER, supra note 86, at 187. He also had written:

From a wealth-maximization standpoint, . . . if $C$ borrows money from $D$ with a penalty clause that provides that im the event of default $D$ can break C's knees, there is no economic basis for refusing to enforce. . . the contract unless some element of fraud or duress is present. Nor would the economist think the promise . . . so irrational as to create an irrebutable presumption that it was procured by fraud or duress or vitiated by insamity or other incapacity.

Posner, supra note 50, at 134. Professor Posner nevertlieless said of the "pound of flesh" transaction, "No commercial reason for this form of penalty clause is suggested." He said that the clause could not withstaud the judicial scrutimy necessary "to ensure that the penalty has an economic function and was not imposed or accepted because of mistake, misunderstanding, fraud, duress, or the like." Concerning the sale of an aborted fetus to cannibals, he wrote, "There is nothing in economics to deny the existence of disgust, a form of negative taste." Letter from Professor Posner to the author (December 2, 1980).

Altlough Professor Posner disagrees, I believe that lis position concerning these cases is incompatible witl the view that the only justifiable limitations on contractual freedom are those of incapacity, fraud, duress, monopoly, and externality. Only a paternalistic desire to save an overconfldent party from the inhuman consequences of an apparently voluntary contract can account for the courts' refusal to enforce "pound of flesh" penalty clauses, and only a socially based concept of externality like the one advanced in this Article can account for prohibition of the fetus sale. As I had written to Professor Posner concerning the "pound of flesh" transaction in a response to his imitial criticism:

Was Sliakespeare's Antorio insane? The indications are that he was a successful merchant of Verice with no history of mental disorders. Did Shylock defraud him? To the contrary, the pound of flesh clause wasn't even in the fine print; Shylock conscientiously brought it up and discussed it with lis borrower. Is it duress that one's wealth is tied up at sea when one's good friend wishes to court the lovely Portia? Not even [the] "expansive contemporary concepts of unconscionability" [tlıat you have said you disapprove] would seize on so feeble an excuse. Was Sliylock a monopolist? Probably not. Antonio was simply so cocky about his ability to perform that he lrappily agreed to the penalty clause witliout searcling out a more conventional moneylender. And to find a problem of "externality" in this contract, you would need to stretch that concept farther than I do.

Although a very extreme penalty clause might be the product of duress or mistake, it also might be the product of an overconfidence like Antonio's. I do not understand how a refusal to enforce the clause in this situation can be reconciled with the principles that Professor Posner has advanced.

More importantly, the concession of any moralistic limitation on the appropriate scope of normative economic analysis seems significant. Again I repeat what I had written to Professor Posner:

If the "pound of flesh" contract slould not be enforced, why not? . . Is it just that the enforcement of this contract would be morally repugnant? If you said so, [a] critic . . . might respoud, "I think it . . morally repugnant that a person should give up his life savings because lie defaulted on an agreement to mow someone's lawn aud because he agreed to a foolish penalty clause." "Yes," [another] critic . . . inight add, "and it's also repugnant that he slould give up half his life savings." And [a third] critic . . . might proclaim it repugnant for the defaulting lawn mower to pay even $\$ 100$ wlien the foreseeable damages caused by his default were only 50 ceuts. We might quickly return to the rule of law that your economic analysis was designed to criticize. We might even restore the ... doctrine of unconscionability, for what is it other than a floating, paternalistic concept of unconscionability that [might] lead [one] to condemn the "pound of flesh" contract? Those of us who are deeply offended by the sale of rights and liberty that plea 
When one considers particular issues of contractual freedom, it sometimes inay be possible to explain one's intuitions in less mystical terms. Some issues of contractual autonomy do lend themselves to rational analysis. Indeed, the contractual issue that is the subject of this Article-the compromise of criminal cases-seems more tractable than many others.

\section{The Concept of Partial Guilt}

The parties to a dispute may seek its resolution in various ways. They may fight until one of them yields, or in an effort to minimize bruises and other "process costs," they may play a game of squash or Scrabble as a substitute for battle. They may even seek the judgment of God by viewing some uncontrollable event as a sign of His will. If the parties seek a peaceful end to their conflict, however, they probably will employ one of two very different dispute-resolution mechanisms. They inay approach a third party - a tribal elder, a federal judge, a priest, a Mafia don, or even a stranger selected at random-and say, "Here is the evidence. Tell us which one of us is right." Or they may compromise: "Let's not argue. We need not determine which one of us is right. It would be fairer just to split the difference." Adjudication can be simply defined as the resolution of a dispute by a disinterested third party. Settlement can be defined as dispute resolution by the parties to the dispute themselves. Adjudication is designed to answer the question of which side is correct on a case-by-case basis. Settlement is not designed to answer this question but to produce an acceptable middle ground. ${ }^{140}$

\footnotetext{
bargaining involves might bring the principle [of] the "pound of flesh" case to bear on this issue as well. . .

Of course these various results would not "follow" froun your concession of one extreine case . . . . Different people would abandon the wealth inaximization principle at different poimts along the spectrum of moral indignation. Nevertheless, once you recognized the propriety of limiting this principle in response to some deeply felt inoral imtuitions, wouldn't it be every person for himself?
}

I told Professor Posner that I would be pleased to report that he was " $\mathrm{m}$ the end an intuitionist like the rest of us." Although his response made it seein likely that he would resist this characterization, this response, at least from some perspectives, may reinforce the necessity of giving inoral intuition its due.

140. The definition of adjudication that this Article has suggested is basically in accord with that advanced by others. Professor Geoffrey C. Hazard has said that adjudication is a procedure for deternining a dispute involving a claim of legal or customary right in which a third party is invested with authority to make a decision that is recognized as binding, except that under soune systems . . . the parties have a right to reach a different disposition by contract after an adjudication. This definition entails the existence of a third party, and hence differentiates the procedure froin ncgotiation; it involves a third party with power to make a binding determination, and hence differentiates the procedure from mediation; it presupposes that the claims are to rights and hence excludes disputes over other matters such as allocation of resources at the disposal of a inultiperson decision maker.

Hazard, Adjudication As a Private Good: A Comment, 8 J. Legal Stud. 319, 319-20 (1979). The 
In civil cases, the propriety of settlement seems virtually unquestioned, and some observers ask why the settlement of crimmal cases should be viewed differently. ${ }^{141}$ The reason cannot be simply that criminal cases involve public interests and civil cases private interests. We often look to civil litigation to vindicate public interests especially when the government is a party. Moreover, the settlement of a crimmal case need not disregard the public interest; it is of course the duty of the prosecutor to insure that it does not. An important distinction between civil and criminal proceedings may lie, however, in their fundamentally different mechanisms and objectives.

The usual goal of civil litigation is compensation. ${ }^{142} \mathrm{~A}$ loss has occurred, and although we might be happier if no one needed to bear this loss, someone must. When the affected parties can allocate the loss in a manner that satisfies thein, the goals of a compensatory system have been fully achieved. We cannot expect litigation to do any better. In civil cases, we therefore tend to view litigation merely as a backstop for disputes that have failed to yield to private settlement. ${ }^{143}$

definition of adjudication that this Article has suggested is somewhat more cxpansive than Professor Hazard's, for it omits the requirement that the dispute involve "a claim of legal or customary right." See Abel, A Comparative Theory of Dispute Institutions in Society, 8 LAW \& Soc'y Rev. 217, 232-39 (1973). If, for example, an ailing nabob were to gather a group of prospective legatees and ask them all to explam why they should be included in his will, his resolution of their conflicting claims would be regarded as a form of adjudication under this Artiele's definition. But see Fuller, The Forms and Limits of Adjudication, 92 HARV. L. Rev. 353 (1978).

141. See, e.g., R. POSNER, supra note 86, at 443.

142. This view of civil litigation is admittedly somewhat oversimphified. A treble-damage action under an autitrust statute, for example, las both compensatory and punitive objectives, and imjunctive actions are designed to prevent rather than to reallocate losses. Nevertheless, this somewhat oversimplified model of civil litigation seems generally appropriate. See Drane \& Neal, On Moral Justifications for the Tort/Crime Distinction, 68 CALIF. L. REv. 398 (1980):

Most systems of justice distinguisl criminal from tortious conduct. They respond to wrongs that are classified as criminal by deliberately infiicting paim on the wrongdoer through the institution of legal punishment. They respond to wrongs that are classified as tortious, on the other hand, . . by requiring that the wrongdoer compensate the victim.

143. Again, it may be overly simple to describe the settlement of a civil case merely as an allocation of loss that the parties find satisfactory, for civil settlements commonly are shaped by the adjudicative mechanisms that society has provided for situations in whieh settlement cannot be achieved. Thus, a defendant in a malpractice action who settled a case for a seemingly outrageous sum because a lawless jury inight have awarded an even larger sunı probably would not describe the settlement as a private allocation of loss that satisfied him. Sinilarly, a civil plaintiff who settled a case for an apparently trivial amount only because he could not afford to wait several years for a trial also would be unlikcly to describe his scttlement in these laudatory tcrms. The ultimate coinplaints of these dissatisfied parties, however, would concern the adjudicative process. At least as a normative proposition, the view that the parties to a civil dispute should be allowed to allocate a loss as they see fit commands widc support. If it were possible to enter a land in whiel the law offered an effective adjudicative backstop for civil disputes but encouraged the parties to accommodate their personal concepts of justice rather than its own, we might regard this regime as ideal. Despite its coercive aspects, our regime of civil settlement may be about as close as we can come to this kind of system. We certainly do not find it distressing when civil settle- 
The goals of the criminal justice system, however, are not compensatory. This system has been designed to influence conduct through its imposition of penalties. As uncomfortable as this fact sometimes may make us, the central purpose of the system is coercion, and the criminal law attempts to achieve its goals primarily through the deliberate infliction of suffering. The purpose of this system certainly is not to make everybody happy. It therefore may seem strange suddenly to seek the virtues of consent at one stage of a stigmatizing, misery-producing, and involuntary proceeding. Indeed, in most nations of the world, although civil disputes are compromised as freely as here, American plea bargaining apparently is regarded as a reductio ad absurdum of our nation's commercial inentality. ${ }^{144}$ The incredulity with which the coinpromise of criminal cases is regarded elsewhere in the world inay reflect an implicit recognition that postarrest bargaims simply do not further the purposes of a system of punishment. Instead, these bargains seen fundamentally inconsistent with the objectives of the criminal law and with the distmctive techmique of social control that it embodies. The effective administration of a system of reward or penalty depends upon an objective determination of whether the reward or penalty is deserved. ${ }^{145}$

With systeins of reward or penalty other than the criminal law, the mappropriateness of compromise usually seems apparent. For example, Professor Kemieth Kipnis has hypothesized a system of "grade bargaiming" in which a teacher would offer a student a favorable grade in exchange for a waiver of his right to have the teacher read the final exainination. ${ }^{146}$ Of course the teacher's offer might be tailored to his impression of each student's scholastic nuerit; the customary objectives of the grading process might not be abandoned obviously or altogether. Moreover, this bargaining system would promote freedom of contract. The teacher, as the authorized representative of the school, would find

ments reflect extra legal values, as indeed they often do. See Eisenberg, Private Ordering Through Negotiation: Dispute-Settlement and Rulemaking, 89 HARv. L. REv. 637 (1976).

144. Professor John H. Langbein quoted a West German newspaper's account of the plea agreement entered by Vice President Agnew: "The resignation occurred as part of a 'cow-trade,' as it can only in the United States be imagined." Langbein, Land Without Plea Bargaining: How the Germans Do It, 78 Mich. L. REv. 204, 212-13 n.35 (1979) (quoting Badische Zeitung, Oct. 12, 1973, at 3, col. 2). For more scholarly expressions of similar incredulity, see, e.g., Stepan, Possible Lessons From Continental Criminal Procedure, in The Economics of CRIME ANd Punishment 181, 196 (S. Rottenberg ed. 1973); Vlasihin, The Prosecutor in American Criminal Procedure: Observations of a Foreign Student, 12 LoY. L.A. L. REv. 833 (1979).

145. Professor Richard L. Abel has observed, "The very characteristics that nake negotiation an attractive process in controversies dominated by a utilitarian calcnlus (where both parties seek to optimize soine instrumental good, usually money) unake it inappropriate where matters of principle are at stake." Abel, From the Editor, 12 LAW \& Soc'y Rev. 189 (1978). See also Langbein, Torture and Plea Bargaining, 58 PUB. INTEREST, Winter 1980, at 43, 55-56.

146. Kipnis, Criminal Justice and the Negotiated Plea, 86 EтHICs 93, 104-05 (1976). 
any compromise that he entered advantageous in terms of proinoting certainty, avoiding the occasional arbitrariness of the grading process, and conserving resources. In addition, a student would not accept the teacher's proposal unless it advanced his interests, and his "adjudicative" option would remain. So long as these parties were satisfied, why should anyone else complain?

The answer, to most of us, seems obvious: Bargained grades simply could not serve the purposes for which grades are awarded, or at least they could not serve these purposes as well as grades deterinined by "adjudication." In this context, many of us might find absurd the suggestion that a teacher beset by conflicts of interest could be trusted to represent the school or the public. We might unhesitatingly reject the argument that the "consent of the parties" was an appropriate objective of what purported to be an evaluative process. And we probably would condemn "grade bargaining" as a perversion of the grading system without any of the elaborate analysis to which most of this Article has been devoted. Moreover, other systems of reward or penalty could provoke a similar reaction. Imagine, for example, the chagrin of a penitent who arrived at the gates of heaven and asked whether he was worthy to enter, only to be told by Saint Peter that it miglit be beneficial for him simply to sphit the difference and to accept a short term in purgatory.

These illustrations may indicate one reason why the settleinent of criminal cases often seenis troublesonie. The coinproinise of a criminal case suggests that a defendant can be lialf-guilty and can properly receive half the penalty that he would receive if he were really guilty. Most people probably adhere to the simpler view that the defendant either committed the crime or did not. If he did, he deserves the penalty that an honest-to-God criminal should receive. If he did not (or, more accurately, if his guilt cannot be proven beyond a reasonable doubt), he should not be punished at all. If the criminal law is to serve its purposes, it may be well that nost folks-in-the-street adhere to this unoralistic view of punishment rather than to the alternative view that guilt is relative, inerely a prediction of what the courts will do in fact. Perhaps, contrary to the frequent argument of bargaining prosecutors that "lialf a loaf is better than none," the criminal justice system loses soinething as an instruinent of social control when it inflicts a halfpunishment on a half-guilty defendant. Perhaps deterrence cannot be measured by the aggregate years in prison that the system ultimately inposes. If the process works at all, it inay be because it reinforces concepts of moral responsibility and moral guilt that cannot properly be coinpromised. Indeed, what Professor Francis A. Allen once said of the substantive criminal law nay be applicable to criminal procedure 
as well: "Any operating system of law ... requires the articulation and application of principles that are comprehensible to persons subject to the law, comprehensible not only in the sense of being capable of rational application, but also of appealing to alinost instimctual feelings of fitness and propriety."147

Of course one who speaks of criminal guilt as a moral concept is likely to be interrupted by a demand to know wlietlier his reference is to "factual" or to "legal" guilt. Some advocates of plea bargaining, acceptimg the view that issues of "factual" guilt should not be compromised, nevertheless, defend the propriety of compromising what they regard as questions of "legal" guilt. ${ }^{148}$ Although it has become fashionable to discuss "legal" and "factual" guilt as though they bore little relationship to one another, they camiot be neatly separated. Indeed, it may be leelpful to empliasize their relationship by offering a tentative definition of "legal" guilt that will admittedly prove inaccurate in some situations: Legal guilt is merely factual guilt as well as it can be discovered through a luman and fallible adjudicative process whose evidentiary rules and standards of proof offer adequate assurance against conviction of the innocent. After considering the situations in which this definition does apply, this Article will consider separately those in which it does not-situations in whicl legal doctrines are expressly designed, not to promote accurate verdicts, but to serve other objectives.

When "legal" guilt is regarded simply as "factual" guilt as well as it can be known to a court or jury, the distinction between the two concepts largely collapses. A prosecutor or other observer who asserts that a defendant is "factually" guilty although this defendant might not be convicted at trial simply presumes his own superiority as a fact-

147. F. Allen, Law, Intellect, and Education 105 (1979). Cf. Selznick, Jurisprudence and Social Policy: Aspirations and Perspectives, 68 CALIF. L. REv. 206, 216 (1980) ("The more integrated law is with what people accept as sensible, the easier it is to make the system work.").

148. See, e.g., C. Silberman, Criminal ViolenCe, Criminal Justice 280-82 (1978); Schulhofer, supra note 37, at 792-94; White, A Proposal for Reform of the Plea Bargaining Process, 119 U. PA. L. Rev. 439, 458-62 (1971). These observers tend to use the concept of "legal" guilt in a somewhat peculiar way. One might suppose that a defendant would be "legally" guilty if he had been declared guilty by a court authorized to make this determination. On this view, any defendant who is lawfully induced to plead guilty becomes "legally" guilty however weak the evidence against him and however innocent he may be in fact. Paradoxically, the defenders of plea bargaining seem to exclude convictions by guilty plea from their concept of "legal" guilt; they apparently do not regard a defendant as "legally" guilty merely because he has been persuaded to accept a prosecutor's offer. Their reference is exclusively to the trial process, and remarkably, they manage to speak of "legal" guilt although no trial has taken place. Bending an apparently retrospective concept so that it becomes anticipatory, they suggest that a defendant is "legally" guilty if he would be found guilty by a court or jury at trial, and he is "legally" innocent if he would be acquitted. E.g., Church, supra note 11, at 515; McDonald, Cramer \& Rossman, Prosecutorial Bluffing and the Case Against Plea Bargaining, im W. McDonald \& J. Cramer, Plea BargainING 1, 6 (1980). 
finder to the body that has been authorized by law to make this determination. This observer asserts the superiority of his personal factfinding inethods to the procedures that the legal system has devised and refined over the centuries for the resolution of factual disputes. Typically, a person who claims that a defendant is "factually" but perhaps not "legally" guilty questions the requirement of proof beyond a reasonable doubt, or else he imphcitly questions the wisdom of an evidentiary rule designed to proinote accurate verdicts. He may, for example, claim to "know" that a defendant is factually guilty because of statements by witnesses who have since disappeared-statements that under the confrontation clause ${ }^{149}$ cannot be presented to a jury. The perception that apparently informed the confrontation clause, however, was that statements not presented in open court and not subject to crossexamination cannot be regarded as trustworthy. This perception may have been maccurate, but it should not be the function of a crimimal justice administrator effectively to revise this constitutional judgment by proclaiming a defendant "factually" guilty on the basis of this madmissible evidence. ${ }^{150}$

The distimction between "factual" and "legal" guilt is no more easily drawn in practice than in principle. Whatever the theoretical content of these concepts, an attempt to limit plea bargaining to questions of "legal" rather than "factual" guilt surely would prove unworkable. However severe his difficulties of proof, a prosecutor who wished to enter a plea agreement almost certainly could persuade himself that these difficulties raised only issues of "legal" guilt. Indeed, a truly zealous prosecutor imight "know" that a defendant was factually guilty even if all of the state's witnesses had recanted their testimony and had proclaimed the defendant's innocence, and his cynical view might even be reinforced by the willingness of the defendant to plead guilty im response to sufficiently dramatic concessions. Many observers seem to "know" that factually innocent defendants never plead guilty even when the bargains that they have been offered have been dehberately calculated to overbalance their chances for acquittal. ${ }^{151}$ Fimally, when a prosecutor does entertain serious doubts concerning a defendant's factual guilt, he is likely to decline to prosecute; one result is that the prosecutor is likely to see all cases in which he does proceed as presenting only questions of "legal" guilt. If the impulse to distinguish between "legal" and "factual" guilt rests on the view that it is pennissible to induce a defendant to plead guilty when one "knows" that he is guilty in fact, the practical effect may be to give prosecutors an open

149. U.S. CoNST. amend. VI.

150. See Alschuler, supra note 7, at 1127 n.226.

151. See Menna v. New York, 423 U.S. 61, 62 n.2 (1975) (per curiam). 
field. ${ }^{152}$

Whenever it truly is possible to know a defendant to be guilty despite the state's inability to prove his guilt at trial, existing evidentiary rules and legal procedures seen defective (that is, when rules designed for purposes other than the promotion of accurate verdicts are set aside). These evidentiary rules and legal procedures may merit revi-

152. Of course one might approach the issue of "legal" and "factual" guilt in a different way by specifying inore precisely the types of questions that seem suitable for compromise and those that do not. The exclusion of unlawfully seized evidence, for example, raises only a question of "legal" guilt, and the compromise of a disputed fourth amendment issue might therefore be permitted. The accuracy of an identification, however, is an issue of "factual" guilt, and the compromise of a question of identification might be forbidden even when a prosecutor has no doubt that the defendant's evidence is contrived and that he is "factually" guilty. With many issues, however, the appropriate characterization seems problematic. For example, Professor Herbert L. Packer once proclaimed that insamity was inerely an issue of "legal" guilt, H. PACKER, supra note 98, at 166, but Professor Stephen J. Schulhofer, with equal confidence, recently declared that this issue was one of "factual" guilt. Schulhofer, supra note 37, at 792-93. Professor Schulhofer did recognize that the characterization of other issues might be difficult, and he refused to take a position on whether the absence of a critical prosecution witness would raise a question of "factual" guilt. Id. at 793 n.230.

Charles E. Silberman, who wrote that "when the facts are in dispute . . a jury trial is the most appropriate means of adjudication," C. SILBERMAN, supra note 148, at 282 (emphasis omitted), also provided a partial list of issues that, in his view, were suitable for compromise: "premeditation, intent, force, credibility, negligence, threat, recklessness, and harm." Id. at 281. In a similar vein, Professor Arnold Enker suggested that questions of mistaken identification should be distinguished from questions that involve "the passing of value judgments on the aceused's conduct as . . . where negligence, recklessness, reasonable apprehension of attack, use of unnecessary force, and the like are at issue." Enker, supra note 37, at 113.

The direction in which this analysis apparently proceeds is toward an extraordinarily limited concept even of "factual" guilt and toward the restoration of a legal system in which the mere production of harm is sufficient for criminal condemnation. Although observers like Silberman and Enker apparently have no objection to the conviction of a defcndant through compromise so long as the police and prosecutor have charged "the riglt person," the criminal law long has regarded something more as essential; plainly it loas regarded disputes about intention, causation, self-defense and the like as potentially important disputes about "factual" guilt.

After extensive analysis and debate concerning the meaning of "legal" and "factual" guilt, one inight devise a rather artificial list of questions that could properly be compromised and those that should be resolved through trial. Even then, however, it would be difficult for criminal justice administrators to draw the lines that this approach apparently would require. It would seem unrealistic, for example, to expect a prosecutor to grant concessions to a defendant who raised a "legal" imsarity defense while withholding all concessions to a defendant who not only alleged msanity but denied in addition the "factual" mens rea required for the commission of his alleged crime. Moreover, a defense attorney in a case that presented both factual and legal issues might attenupt to eliminate the factual issues by "stipulation" so that concessions would become available; it is difficult to see how a mutual decision simply to disregard all issues of "factual" guilt could be prevented. Indeed, when prosecutors were bargaining without restraint in other cases, it would seem naive to expect them to disregard their interest in obtaining bargamed convictions im cases in which the facts were in dispute. They nnight manipulate amorplous questions of characterization to permit plea bargaining in virtually every case. Once agam, some defenders of plea negotiation apparently have considered their task complete once they have identified a situation in which coinpromise seems to them defensible. They apparently have ignored problems of administration and lave failed to suggest any means by which the scheme that they envision could be impleniented. 
sion, but there are direct, constitutional meclianisms for accomplishing the change. The rules do not require sub rosa elimination by prosecutors and judges who claim to know better than legislators, appellate courts, and the framers of the Constitution wliat evidence slould be trusted. Moreover, proponents of the distinction between "legal" and "factual" guilt might be shocked by the suggestion that doctrines like the confrontation clause and the requirement of proof beyond a reasonable doubt should be altered, and whenever legal procedures are appropriate-whenever these procedures do promote accurate verdicts within the confines of an adjudicative system that gives appropriate protection to defendants who may be innocent-the claim that a prosecutor "knows" a defendant to be guilty althougl the defendant's guilt cannot be proven should be viewed with extreme skepticism. Society should not legitimate the prosecutor's presumption that he can determine guilt more accurately than a court or jury by authorizing the compromise of questions that he or someone else lias decided mvolve merely issues of "legal" guilt. Typically the concepts of "legal" and "factual" guilt are not distinct, and the pretense that tliey are masks an arrogant willingness to abandon constitutional and other legal safeguards agamst conviction of the innocent.

Some evidentiary and procedural rules, lowever, are not designed to promote accurate verdicts. When these rules apply, the tentative definition of "legal" guilt that this Article has advanced becomes maccurate, and a more meaningful distimction between "factual" and "legal" guilt can be drawn. The most cominonly invoked example of a truth-denying legal doctrine is probably the fourth amendment exclusionary rule. ${ }^{153}$ One suspects in fact that many of tlose who would permit the compromise of questions of "legal" but not "factual" guilt seek primarily to authorize the compromise of fourtl amendment issues. Surely a defendant can be said to be "factually" guilty although the evidence against him was uncovered unlawfully so that he cannot be convicted at trial, and other defendants who are the beneficiaries of

153. Indeed, the fourth amendment exclusionary rule is almost the only "pure" example of a truth-denying legal doctrine in our system of criminal justice. Even the right to a speedy trial and statutes of limitations, which sometimes lead to the nonconviction of "factually" guilty defendants, are designed in part to prevent inaccurate convictions on the basis of "stale" evidence. Similarly, the right not to be placed in twice jeopardy for the sane offense has been justified partly on the ground that allowing the state a second chance to convict could lead to conviction of the innocent. Moreover, ınost restrictions on the adınissibility of confessions rest partly on the view that improperly obtained confessions may be untrustworthy. Some observers have even suggested that a defendant's right not to testify at trial is designed in substantial part to protect innocent defendants. The only "pure" example of a truth-denying legal doctrine that comes to mind apart from the fourth amendment exclusionary rule is the rule that permits a defendant to challenge the racial composition of the grand jury that indicted him even after his conviction by a properly selected trial jury. See Seidman, supra note 74, at 449-55. 
truth-denying legal doctrines can also be said on occasion to be "factually" but not "legally" guilty. ${ }^{154}$

Every truth-denymg legal doctrine reflects a judgment that, as important as the accurate determination of "factual" guilt certainly is, another social objective is more compelling. Accordingly, in terms of the social importance of the issue, there may be less justification for coinpromising a question of "legal" guilt than for compromising a question of "factual" guilt. Although one sometimes may be suspicious of judgments that factually guilty defendants should be freed for the sake of proinoting "extraneous" objectives, this issue certainly should be faced directly im deciding whether a truth-denying legal doctrine is worthwhile. To undercut a truth-denying legal doctrine through plea bargaining is to reassess the social judgment that led to the doctrine's establishment.

The object sought by a truth-denying legal doctrine may or may not be related to fair treatment of the defendant. With the fourth amendment exclusionary rule, for example, the Supreme Court has said that the object is simply the prevention of future police illegality. ${ }^{155}$ In this situation, the impulse to distinguish "factual" from "legal" guilt may stem from the recognition that a conviction through compromise would not be unfair to the "factually" guilty defendant himself. By the same token, however, a conviction at trial would not be unfair to the "factually" guilty defendant. The sentiment that apparently prompts the distinction between "factual" and "legal" guilt in this context seems to bear far more on whether an exclusionary rule or other truth-denying doctrime is justified than on whether compromise is appropriate. All truth-denying legal doctrines embody a judgment that "factual" guilt alone should not lead to conviction. The advocates of plea bargaining have failed to explain why this judgment should be applicable to cases that are tried but inapplicable to cases that are settled.

When a truth-denying legal doctrine is designed to protect interests other than the defendant's, the relevant question is not whether compromise would be unjust to the defendant himself but whether this compromise would advance or retard the "extraneous" interests that the doctrine was intended to promote. If, for example, one repudiates a "rights" theory of the exclusionary rule and accepts the Supreme Court's utilitarian view of this doctrine, the relevant issue is whether

154. It bears emphasis, however, that this conclusion can fairly be drawn only of these defendants (unless one wishes to criticize a doctrine designed to promote accurate verdicts as failing to accomplish its goal).

155. E.g., Michigan v. DeFillippo, 443 U.S. 31,38 n.3 (1979); Stone v. Powell, 428 U.S. 465, 492 (1976). 
the compromise of fourth amendment issues would sacrifice the pubhic's interest in enforcing the law agamst the law enforcers.

From this perspective, the exclusionary rule should itself be regarded as a system of reward or punishment. It is, however, a distinctive systein, one that does not inflict any suffering upon a lawless police officer but that merely follows a judicial determination of lawlessness with a partial restoration of the status quo ante. It nay seem doubtful that this sanctioning system, which deprives an officer of some improper gain but gives him nothing to lose, could deter his illegality. If it could, lowever,

[o]nly a thorough-going demonstration that illegal conduct will be unproductive seeins likely to influence [the officer's] behavior . . . . An officer should be discouraged from thinking, "I know that it is probably illegal to enter this apartment; but the prosecutor nay nevertheless be able to make soinething of the case. He seeins able to get some kind of guilty plea froin almost every defendant, and I can therefore be reasonably confident that the defendant will be convicted of something."156

Moreover, if the exclusionary rule seems unlikely to have a deterrent effect, it nevertheless may have what soine observers (usually referring not to this rule but to the substantive criminal law) have called a moral-educative effect. These observers have recognized that a system of sanctions can influence conduct not only through a specific pleasurepain calculus but through example and habit formation. ${ }^{157}$ It is a fact wortlyy of careful consideration that prior to the Supreme Court's decision in Mapp v. Ohio, ${ }^{158}$ courts in non-exclusionary rule states had virtually no occasion to rule on the legality or illegality of police seizures. The constitutionality of these seizures was simply irrelevant to any issue that was likely to come before the courts, and judges therefore subjected police seizures to almost no review and gave police officers almost no guidance concerning the propriety of their behavior. Despite the extent to which plea negotiation has subverted the goals of the exclusionary rule, I believe that police conduct has changed for the better in the years since Mapp was decided and partly as a result of this decision. ${ }^{159}$ The principal reason has not been that lawless officers feared the sanction of exclusion; not only were these officers likely to profit in various ways from unlawful seizures even when the resulting evidence

156. Alschuler, supra note 59, at 83.

157. See, e.g., Andenaes, General Prevention, 43 J. CRIM. L.C. \& P.S. 176, 179-80 (1952); Andenaes, The General Preventive Effects of Punishment, 114 U. PA. L. Rev. 949 (1966). For a discussion of the possible moral-educative effect of the exclusionary rule itself, see Oaks, Studying the Exclusionary Rule in Search and Seizure, 37 U. CHI. L. REv. 665, 711, 729 (1970).

158. 367 U.S. 643 (1961).

159. Compare 1 W. Lafave, Search and Seizure: A Treatise on the Fourth AmendMENT 28-29 (1978) ("the exclusionary rule has provided an essential stimulus to the judicial elaboration of Fourth Amendment requirements"). 
was excluded, but truly lawless officers often could prevent exclusion by fabricating the facts. Instead, the primary reason has been almost the opposite-that essentially law-abiding officers have taken seriously the legal guidance that the courts have provided. In judging the exclusionary rule, commentators may have followed too closely Justice Holmes' advice to view law from the perspective of a "bad man" who wishes only to evade it. ${ }^{160}$ Perhaps the "good person of the law" also merits soine attention.

The inoral-educative effect of the exclusionary rule is plainly sacrificed when fourth amendment disputes are compromised. A plea agreeinent produces no authoritative ruling on the propriety of police conduct. It can at most persuade an officer that any behavior that gives a defense attorney even a "talking point" is likely to result in a reduction in sentence. This limited message-not that certain police conduct is wrong but merely that it may affect a suspect's sentence-is commonly conveyed in a situation in which the officer's failure to act is likely to result im his failure to discover or apprehend a "factually guilty" defendant. Indeed, when fourth amendment disputes are compromised, the exclusionary rule may continue to impose significant costs while yielding only the most ephemeral gains.

This Article will not analyze other truth-denying legal doctrines in an effort to determine whether their purposes are likely to be advanced or hindered by compromise. The burden plainly should rest with those who contend that the compromise of questions of "legal" but not "factual" guilt is appropriate to explain why, to indicate how they would draw the line between these concepts, and to suggest how any line that they might propose could be incorporated into an operational systein of plea bargaining.

\section{E. The Settlement of Criminal Cases and the Risk of Convicting the Innocent}

Although this Article has maintained that the compromise of crimmal cases reflects a concept of partial guilt inconsistent with the purposes of the criminal law, it has not directly addressed the question whether plea bargaining is more likely than trial to result in the conviction of factually innocent defendants. Because there can rarely be a more authoritative determination of guilt or innocence than the judgment of a court, this question is not subject to empirical evaluation. A judgment of conviction, whether by trial or by plea, can be shown to be erroneous only in exceptional situations in which a corroborated confession by solneone other than the defendant or another piece of previ-

160. See Holmes, The Path of the Law, 10 HaRv. L. Rev. 458, 459-62 (1897). 
ously unknown evidence demonstrates the error. Popular descriptions of these exceptional incidents commonly do, however, reveal erroneous guilty-plea convictions. ${ }^{161}$ Moreover, although an authoritative empirical answer cannot be given, the sensible nonempirical answer seems plain: A procedure that is designed to determine who is guilty and who is innocent seems almost certam to accomplish this task more effectively than a procedure that is dehberately designed to evade the issue.

Even if the function of plea negotiation were merely to vector the risks of litigation, the practice would certainly yield a larger number of wrongful convictions than trial. Many contemporary advocates of plea bargaining would contend, however, that this injustice could be offset by the lighter sentences that improperly convicted defendants would receive. These observers apparently perceive no difference between, on the one hand, a system in which each of ten innocent but risk-averse defendants senses a ten percent chance of conviction at trial and accepts a sentence of one year and, on the other hand, a system in which nine innocent defendants are acquitted at trial while one, wrongly convicted, is sentenced to ten years. In both situations, as these observers would note, the legal system has yielded the same number of years of unwarranted imprisonment. There may, however, be a difference between these situations apart from the greater number of wrongful convictions produced by a system of plea bargaiming-the difference between a criminal justice system that tries to find the truth and sometimes fails and one that apparently does not care. Indeed, although those who measure justice only by a statistical "bottom lime" might scoff at this suggestion, even the one defendant wrongly convicted at trial might sense this difference; despite his longer sentence, he might be less embittered by a mistaken assessment of the evidence im his case than all of the innocent defendants would be by a system im which no one truly wished to listen to the evidence at all.

Moreover, a plea negotiation system that merely vectored the risks of litigation would leave the benefits and risks of litigation im balance from the defendant's perspective; it might therefore yield a guilty-plea rate of about fifty percent. Guilty-plea rates in America are substantially higher, ${ }^{162}$ and one reason is that prosecutors are not content merely to vector the risks of litigation. For a variety of reasons including the pressure of their caseloads, they usually would rather not try their cases. Accordingly, they tailor their offers not to balance but to

161. See E. Borchard, Convicting The Innocent 112-22, 367-70 (1932); E. Gardner, The Court of Last Resort 313-14 (Cardinal ed. 1954); E. Radin, The InNocents 151-56 (1964).

162. See note 1 supra. 
overbalance a defendant's chances of acquittal. As Professor Welsh S. White reported:

[A] Philadelphia ... prosecutor related that in one case he reduced his guilty plea sentence recommendation by two thirds in order to induce a defendant who had a forty percent chance of acquittal to forego trial. According to Martin Erdman [a distinguished public defender in Manhattan], New York prosecutors often reduce their sentence recommendations by at least fifty percent if they believe there is a fifty percent chance of a hung jury, and by a great deal inore if they believe that there is a fifty percent chance of acquittal. If the chances of acquittal are greater, the practice in both offices is to offer at least proportionally higher concessions. ${ }^{163}$

This process seems well-designed to produce the conviction of innocent defendants.

Observers who deny that plea bargaining is likely to result in conviction of the innocent are usually exceptionally naive or exceptionally cynical. The exceptionally naive simply contend that an innocent person would never plead guilty, whatever the concessions that he has been offered. These observers have an almost mystic faith in the trial process; and they beheve that criminal defendants-even those whose views of the criminal justice system have not been derived solely from Perry Mason-will share this abiding faith.

The exceptionally cynical, by contrast, do not deny that plea negotiation is well-designed to produce the conviction of innocent defendants. They simply deny that there are any innocent defendants. They draw comfort from the words of Judge Learned Hand: "Our procedure has been always haunted by the ghost of the innocent man convicted. It is an unreal dream." 164 They also invoke the wisdom of soine defense attorneys who claim never to have represented an innocent client. Although these attorneys commonly recognize that some of their chents may not have been guilty of the offenses with which they were charged, they add that these chents were always guilty of something else.

In view of the fact that relatively few among us have not been guilty of "something else," these pronouncements do not seem truly decisive of the issue. Moreover, the attorneys certainly do not mean that none of their clients have claimed to be innocent; they mean only that they chose not to beheve the clients' stories. There is hitle reason to suppose that eyewitness identification, to take the most obvious example, has become significantly more rehable or sigmificantly less important over the years; indeed, in a diverse, inobile society like ours, identification testimony often may seem more fallible than it did in

163. White, supra note 148 , at 451 .

164. United States v. Garsson, 291 F. 646,649 (2d Cir. 1923). 
simpler societies in which any stranger was likely to be quickly scrutinized. As a San Francisco prosecutor noted, "The victim of a crime, no matter how reputable, bases his identification on a fleeting moment, usually one of the inost traumatic in his life. My experience has been that the stronger the identification, the nore likely it is that the victim is wrong." 165

People who are charged with crimes may seem disreputable to their attorneys-as well as to others-because they are likely to have prior criminal records, because they are likely to come from lower class backgrounds, because their physical appearance or manner of speech is likely to seem threatening, or for a variety of other reasons. This circumstance, far from warranting a cynical assumption that these defendants must be guilty, seems to emphasize the dangers of bias and mistake in our heterogeneous society-dangers that may make a careful sifting of the evidence especially important. If $I$, a middle-aged, middle-of-the-road, middle-class professor, were charged with a crime, I probably would be guilty; but the chance of false accusation may be substantially greater for others. Moreover, although crimimal cases are subjected to intense pretrial screening im many jurisdictions, there are few jurisdictions in which prosecutors regularly refuse to prosecute cases that depend entirely upon the identification testimiony of a simgle witness. This charging policy may be justified; many rapists, for example, probably would go free if one-witness identification cases were never prosecuted. Nevertheless, the policy has terrifying implications in a system in which a likelihood of acquittal merely yields a sweeter deal. In short, there is no reason to suppose that the danger of convicting innocent defendants through the plea negotiation process is negligible or that this danger can be equated witl the danger of convictimg innocent defendants at trial.

\section{ConClusion}

I readily concede that nost of the views expressed in this Article coine straight from the nineteenth century. In 1868, the Michigan Supreme Court observed:

The doctrine rests upon assent; in other words, when reduced to its final analysis, upon contract. ...

But a criminal prosecution, in which the people in their sovereign capacity prosecute for a crime against the laws of the whole society, and seek to subject the defendant to punishment, must, it seems to us, be considered as a proceeding in invitum, against the will of the defendant throughout . . . . It would be adding materially to the generally recognized force of the obligation of contract to hold that a defendant

165. Alschuler, supra note 59, at 63 (statement of Francis W. Mayer). 
charged with crime might, without a trial, enter into a binding contract with the prosecuting attorney . . . to go to the penitentiary for a certain nuinber of years in satisfaction for the offense. . . .

The true theory, we think, is that the people . . . assuine to provide by law the proper tribunals and modes of trial for offenses, without consulting the wishes of the defendant as such; and upon thent, therefore, devolves the responsibility, not only of enacting such laws, but of carrying thein into effect, by furnishing the tribunals, the panels of jurors, and other safeguards for his trial, in accordance with the constitution . . . 166

Although plea negotiation is defended sometimes as a sentencing device and sometimes as a form of dispute resolution, the practice that merges these distinct tasks also performs another function-administering our overburdened criminal justice system. There are those who contend that this last function is critical. Indeed, they often suggest that the issues discussed in this Article are academic, arguing that our courts have become so thoroughly dependent on plea bargaining that we cannot consider the prohibition of this practice however unjust it may seem. This argument-perhaps the inost pernicious of the myths surrounding the plea negotiation process-requires more careful consideration than this already lengthy Article can provide; it will be the topic of my next piece of writing on this subject.

166. Hill v. People, 16 Mich. 351, 357 (1868). Even earlier, in 1858, the New York Court of Appeals had expressed a similar viewpoint:

There is, obviously, a wide and important distinction, between civil suits and criminal prosecutions, as to the legal right of a defendant to waive a strict substantial adherence to the estabhished, constitutional, statutory and common law mode and rules of judicial proceedings. This distinction arises from the great difference in the nature of such cases, in respect to the interests involved and the objects to be accomplished.

Civil suits relate to and affect, as to the parties against whom they are brought, only mdividual rights which are within their individual control and which they may part with at their pleasure. The design of such suits is the enforceinent of merely private obligations and duties. Any departure from legal rules in the conduct of such suits, with the consent of the defendants, is therefore a voluntary relinquishment of what belongs to the defendants exclusively; and hence there is a manifest propriety in the law allowing such consent to have the effect designed by it . . . .

Criminal prosecutions involve public wrongs . . . which affect "the whole cominunity, considered as a comunumity, in its social and aggregate capacity." . . . The end they have im view is the prevention of similar offenses . . . The penalties or punishments, for the enforcement of which they are a means to the end, are not within the discretion or control of the parties accused; for no one lias a right, by his own voluntary act, to surrender his liberty or part with his life. . . . These considerations make it apparent that the right of a defendant in a criminal prosecution to affect, by consent, the conduct of the case, should be nuch more limited than in civil actions.

Cancemi v. People, 18 N.Y. 128, 135-37 (1858). 


\section{APPENDIX A \\ The Lesser Penological Rationales For Plea Bargaining}

In its 1968 effort to justify differential leniency for guilty plea defendants, the American Bar Association Project on Standards for Criminal Justice contended that charge and sentence concessions might be appropriate when "the defendant by his plea has aided in ensuring the proinpt and certain application of correctional measures to him."167 Although the Supreme Court apparently has endorsed this argument, ${ }^{168}$ it is one that the ABA las since repudiated. ${ }^{169}$

In support of its earher position, the ABA relied upon Jeremy Benthain's classic analysis of the muportance of proinpt and certain punishment as a deterrent to crime. It said, "It has long been recognized that pumshment need not be as severe if it is certain and proinpt in apphcation." 170 Of course Bentham spoke of the calculation that a potential offender might make before conumitting a crime. If this person recognized that a criminal act would lead quickly and inevitably to punishment, he would be likely to remain law-abiding.

It is worth comparing the position of the potential offender whoin Bentham envisioned with that of a potential offender in America today. Today's potential offender might recognize that our system of criminal justice affords extraordinary opportunities for delay. ${ }^{171} \mathrm{He}$ night also recognize that liberal prosecutorial charging policies, coinplex evidentiary rules, elaborate trial procedures, and a sometimes idiosyncratic jury system tend to make punishnient of the guilty far from certain. Of course this potential offender might also know about plea bargaining, but it seems doubtful that this awareness would add to the in terrorem effect of the criminal law. To the contrary, a potential offender would recognize that a defendant ordmarily enters a bargained guilty plea only when this alternative seens even less threatening than our very unBenthamite long-form procedure. It would plainly be a perversion of Bentham's position to suggest that a potential offender might refrain from crime, not out of fear that the criminal justice system would punish him proniptly, but out of fear that he might proinptly pumsh himself because prosecutorial offers are too generous to refuse.

The ABA also argued that concessions to defendants who plead guilty might be appropriate when "the concessions will make possible alternative correctional measures which are better adapted to achieving rehabilitative, protective, deterrent or other purposes of correctional treatment, or will prevent undue harm to the defendant from the form of conviction ...."172

167. 1968 ABA STANDARDS, supra note 11 , at $\$ 1.8(\mathrm{a})(\mathrm{i})$.

168. See Santobello v. New York, 404 U.S. 257, 261 (1971); Brady v. United States, 397 U.S. 742,752 (1970).

169. 1979 ABA STANDARDS, supra note 11 , at 17.

170. 1968 ABA STANDARDs, supra note 11, at 39.

171. See Alschuler, supra note 8, at 1231-33.

172. 1968 ABA STANDARDS, supra note 11, at $\S 1.8(\mathrm{a})(\mathrm{iii})$; accord, 1979 ABA STANDARDS, supra note 11, at $\S 14-1.8(a)(i i)$. 
What the ABA meant by this elaborate language was that it did not like the mandatory sentences attached to some offenses and the stigmatizing labels and collateral civil disabilities attached to others. Moreover, the ABA's commentary recognized frankly that plea bargaining was a second-best solution to these problems: "The most desirable solution ... . would be reform of the sentencing laws so as to give trial judges more discretion."173

In the absence of legislative reform, the $\mathrm{ABA}$ apparently believed that plea bargaining could be defended as a form of guerilla warfare agamst unjust laws. Its commentary did not discuss the obvious problems of democratic theory and of separation of powers that arise when prosecutors and trial judges substitute their personal concepts of justice for those that legislative bodies, acting within their constitutional authority, have enacted into law. All in all, the ABA's position seemed an odd one for a group that purports to revere the rule of law to adopt.

Perhaps, however, criminal justice administrators should nullify harsh laws in particular cases. Indeed, the legislative process may depend on the assumption that they will do so. Even on this view, plea negotiation remains an undesirable mechanism of nullification, for it limits equitable concessions to defendants who have waived the right to trial. Administrative or judicial nullification, if appropriate, probably ought to turn on the defects of the law being nullified or on the nierits of a defendant's case rather than on the extent to which a defendant has eased a prosecutor's or judge's burdens. When the penalties attached to one offense seeni too harsh, for example, a prosecutor might well charge a less serious offense without knowing whether or not the defendant would plead guilty. As I have written elsewhere, "To say that mercy may be given is not to say that mercy should be sold." 174 The ABA's argument that current sentencing laws are often too harsh offered no distinction between guilty-plea and trial defendants, and it therefore offered no justification for plea bargaining.

The ABA next maintained that concessions to a guilty-plea defendant might be justified because "the defendant has made public trial umiecessary when there are good reasons for not having the case dealt with in a public trial ...." 175 The victim of a crime, especially a sex crime and especially a very young victim, nray be seriously embarrassed and emotionally upset when required to testify about the crime at a public trial. The victim's powerful interests, however, are not the only ones at stake. Not only is the defendant's interest in obtaining a public trial protected by the Constitution, but the Supreine Court recently held that the interest of the public in attending criminal trials is so compelling that evcn the desire of both the defendant and the prosecutor for privacy cannot justify the public's exclusion. ${ }^{176}$

173. 1968 ABA STANDARDS, supra note 11 , at 45 .

174. Alschuler, Book Review, 46 U. CHI. L. REv. 1007, 1032 (1979).

175. 1968 ABA STANDARDS, supra note 11, at \& 1.8(a)(iv); see 1979 ABA STANDARDS, supra note 11 , at $\$ 14-1.8(\mathrm{a})(\mathrm{iii})$.

176. Richmond Newspapers v. Virginia, 100 S. Ct. 2814 (1980). The Court did indicate that stronger interests might render the exclusion permissible, and these interests conceivably could include the privacy of a child victim coupled with the defendant's consent. See id. at $2840-41 \mathrm{n} .5$ 
Chief Justice Burger's plurality opinion in Richmond Newspapers v. Virginia $^{177}$ 1naintained that the public's presence at criminal proceedings can give "assurance that the proceedings [are] conducted fairly to all concerned" and can discourage "perjury, the inisconduct of participants, and decisions based on secret bias or partiality." The opinion also noted that "the open processes of justice" can provide "an outlet for community concern, hostility, and emotion" and can satisfy "the fundamental, natural yearning to see justice done." The opinion referred to "the educative effect of public attendance," noted that "the appearance of justice can best be provided by allowing people to observe it," and said, "People im an open society do not demand infallibility from their institutions, but it is difficult for them to accept what they are prohibited from observing."178

If one assumes that Richmond Newspapers will not be extended to backroom bargaining sessions, ${ }^{179}$ plea negotiation will provide an easy mechamism for circumventing all of the values that the Chief Justice articulated. Indeed, the bargaming process will continue to frustrate these value in the overwhelming majority of criminal cases. Perhaps, however, because "it is difficult for [the public] to accept what they are prohibited from observing," the secrecy of plea bargaining should not be regarded as a virtue even in cases in which victinus would be seriously embarrassed by testifying.

Moreover, to say that some kinds of evidence should not be heard in public is not to say that they should not be heard at all. The ABA's reasoning at most suggests that prosecutors should be allowed to bargain for a waiver of the defendant's right to the presence of the public at his trial, not that they should be allowed to bargain for a waiver of the right to trial itself. A inore limited waiver by the defendant-a waiver only of the right to public attendancecould presumably be purchased with a smaller sacrifice of the state's penological objectives than a waiver of the right to any hearing. This linited waiver apparently would satisfy the ABA's goals. ${ }^{180}$ Thus, even in the small nuunber of cases im which the ABA's argument might apply, it could not justify plea bargaining. A less restrictive alternative would remaim.

The ABA also argued that a guilty-plea defendant might properly be rewarded if he had "given or offered cooperation when such cooperation has resulted or may result in the successful prosecution of other offenders engaged in equally serious or more serious criminal conduct." 181 In this argument, the ABA defended, not bargaining for pleas of guilty, but bargaining for testimony or infornation. This Article has previously indicated the significant dif-

(Stewart, J., concurring). But see Lexington Herald Leader Co. v. Tackett, 601 S.W.2d 905 (Ky. 1980).

177. 100 S. Ct. 2814 (1980).

178. Id. at 2825 .

179. See id. at 2839 n.23 (Brennan, J., concurring).

180. Of course, under Richmond Newspapers even an unbargained waiver of the right to an open trial might be held constitutionally ineffective. If it were, however, the reason would be only that the public's interest in attending criminal proceedings outweighed the ABA's concerns.

181. 1968 ABA STANDARDS, supra note 11, at § 1.8(a)(v); accord, 1979 ABA STANDARDS, supra note 11, at \& 14-1.8(a)(iv). 
ferences between these two practices. ${ }^{182}$

The ABA's final argument was that charge and sentence concessions could be appropriate when "the defendant by his plea has aided in avoiding delay (imcluding delay due to crowded dockets) in the disposition of other cases and thereby has increased the probability of prompt and certain apphication of correctional measures to other offenders." 183

It seems doubtful that any defendant, when asked his reason for pleading guilty, would respond, "I want to be out of the way so that other defendants can get what is coming to thein." The ABA's argument did not suggest any magnanimity or strength of character on the part of a guilty-plea defendant; it was instead an elaborately dressed version of the cost-saving utilitarian argument that this Article has considered. ${ }^{184}$ Indeed, the ABA itself apparently rejected this argument in its commentary to this standard: "A defendant should not save two years (or whatever the reduction may be) merely because he has saved the state $\$ 500$ (or whatever the cost of the trial may be). This kind of exchange cannot be justified under any of the accepted theories of punishment." 185

It is difficult to see inuch difference between "saving the state the costs of a trial" and "pronioting the prompt and certain apphication of correctional measures to other offenders." If the state would spend the money needed to operate an additional courtroom, it could of course achieve the sane promptness and certainty in punishing other offenders without the defendant's plea. Indeed, when the recently revised ABA Standards rejected the ABA's earlier argument on this point, they said: "The solution for crowded criminal dockets is the availability of sufficient personnel and other resources, so that prompt trials can be readily given to all defendants who want then1."186

One rationale for differential sentencing not advanced by the ABA has considerable currency among trial judges. When a judge is asked whether he usually sentences defendarits who are convicted at trial more severely than those who plead guilty, a cominon response is that although the judge does not approve of penalizing a defendant's exercise of the right to trial, he is likely to have nuch less sympathy for a defendant after hearing detailed evidence of his crime than when the judge works primarily from a "cold" presentence report following a plea of guilty. ${ }^{187}$

182. See notes 41-42 and accompanying text supra.

183. 1968 ABA STANDARDS, supra note 11, at $\S 1.8(a)(v i)$. Contra, 1979 ABA STANDARDS, supra note 11 , at 17 .

184. See text accompanying notes 41-74 supra.

185. 1968 ABA STANDARDS, supra note 11, at 50.

186. 1979 ABA STANDARDS, supra note 11, at 17.

187. See, e.g., M. Rubinstein, S. ClARKe \& T. White, supra note 83, at 91 (statement of an unidentified superior court judge: "Very probably a judge sentences heavier for going to trialbut that's because he hears a full description of a broken, bleeding victim"); Proceedings of the Pilot Institute on Sentencing, supra note 25, at 287 (statement of Judge George H. Boldt); Commeut, supra note 13 , at 218 .

A recent en banc decision of the United States Court of Appeals for the Fifth Circuit adverted to this issue and also illustrated the flexibility of which the judicial mind sonetimes is capable when plea bargaining issues arise. In Frank v. Blackburn, 28 CRM. L. REP. (BNA) 2293 
This argument plainly assumes that the evidence presented at trial is more likely to be aggravating than mitigating, and some defense attorneys have contended that this assumption is unwarranted. They have maintained that the trial process ordmarily enables a sentencing judge better to understand a defendant's motivation and to recognize his human quahities. They also have observed that even the state's evidence of the defendant's crime often suggests, not its unusual cruelty, but its victim-precipitated character.

If one accepts the trial judges' assumption concerning the usual significance of the evidence presented at trial, their argument inay explaim some small part of the sentence differential but cannot justify it. If the evidence presented at trial is likely to be inflammatory and prejudicial, presumably the task of sentencing should be assigned to a judge other than the judge who has heard this evidence. If, however, the evidence presented at trial is not only genuinely relevant to the sentencing process but likely to make a significant difference, it probably ought to be heard in every case. The judges' argument merely highlights an additional defect of plea bargaining - that it leads to the imposition of sentences on the basis of imcoinplete information. The respective virtues of knowledge and ignorance do not vary with the plea that a de-

(5th Cir. Nov. 17, 1980) (en banc), a trial judge had on two separate occasions offered to impose a 20-year sentence if a defendant pleaded guilty. The defendant had rejected these offers, and following his conviction at trial, the judge had imposed a 33-year sentence. The Fifth Circuit observed in an opimion by Judge Fay:

While the general information in the hands of the judge at the time of plca bargaining inay have been the same as at sentencing, we find persuasive the trial judge's asscrtion that "the Court had nore graphic, descriptive and detailed evidence of the crime and the character of the individual at the time of sentencing." . . .

... We find nothing in the record of the present case to indicate a "realistic likelihood of vindictiveness" on the part of the trial judge. The sentencing which followed the trial upon the merits saw the judge in possession not only of more detailed facts of the offense itself, but of the flavor of the event and the impact upon any victims. . . .

... The disparity in the sentences offered before and after conviction resulted not from judicial vindictiveness or desire to punish, but only from the judge's reappraisal of all the circumstances, after the trial was completed.

Id. at 2294-95.

Nevcrtheless, if the trial judge had no desire to punish the defendant for rejccting the judge's offer and for exercising the right to trial, the Fifth Circuit did. It observed:

We decided to rehear the case en banc, because of its potentially devastating impact on the plea bargaining process.

...

. . Once the bargain . . is rejected, . . the defendant camot complain that the denial of the rejected offer constitutes a punishment or is evidence of judicial vindictiveness. To accept such an argument is to ignore completely the undcrlying philosophy and purpose of the plea bargaining system. If a defendant can successfully demand the same leniency after standing trial that was offered to him prior to trial in exchange for a plea, all the incentives to plca bargain disappear; the defendant has nothing to lose by going to trial.

Id. at 2294.

The court apparently thought it important that a defendant should have something to lose (something hike 13 years) when he exercised a constitutional right, and the court was probably correct that this view reflects "the underlying philosophy and purpose of the plea bargaining system." It was a marvelous serendipity that this philosophy could be implemented so effcctively through a reassessment of the "flavor of the event" following a trial; one suspcets, in fact, that this sort of serendipity may be a conmion occurrence in the world of some jurists. 
fendant enters, and the fact that sentencing is based on less complete information following a guilty plea than following a trial cannot justify the greater lemency that guilty-plea defendants seem to receive. 


\section{APPENDIX B \\ The Effect of A Plea Bargaining Prohibition on SENTENCE SEVERITY}

Some defense attorneys and other observers undoubtedly favor plea bargaining primarily because they beheve that this practice leads to greater leniency in the aggregate than its alternative. Milton Adler, the Assistant Attorney in Charge of the Legal Aid Society of the City of New York, observed, "The system makes me feel like a pushcart peddler a lot of the time, but at least it's a way of getting a break for a chent."188 For reasons that this Article has suggested, the premises underlying this viewpoint are questionable; one cannot fairly assume that, in the absence of plea bargaining, all eonvicted defendants would be sentenced as severely as the small minority of defendants who are convicted at trial today. ${ }^{189}$

Today's sentence differentials could be eliminated by awarding each defendant who pleads guilty the same sentence that a comparable defendant now receives following a conviction at trial. They could also be eliminated by awardimg each trial defendant the same sentence that a comparable guilty-plea defendant now receives or by imposing soine intermediate sentenee for both the guilty-plea and trial defendants. If the sentences currently awarded to guilty-plea defendants reflect lemiency that cannot be justified on the basis of offense and offender characteristics, one might reasonably expect these sentences to increase as sentencing authorities focused more on the merits of individual cases and less on a bureaucratie desire to move these cases rapidly through the courts. Similarly, if the sentences currently awarded to trial defendants rest partly on instrumental objectives and therefore refleet undeserved severity, one might reasonably expect these sentences to decline. In either event, sentences based more on the merits and less on admimistrative concerns seem desirable. The fear of a plea bargaming prohibition that defense attorneys commonly express may reveal their implieit recogmition that some of the concessions that plea bargaming now provides to their clients eannot be justified on the merits. Alternatively, defense attorneys often may beheve that these concessions are justified but that judges would be unlikely to recognize this fact; in other words, they may favor plea bargaining simply on the ground that their own concepts of justice are preferable to the judgments of less partisan judicial officers.

It is far from elear, however, that a prohibition of plea bargaining would lead to more severe sentences. Although, as an empirical matter, the dynamics of differing procedural systems probably do affect the level of sentence severity, a great deal may depend on what sort of adjudieative system would replace today's bargaining practices. As an important study by Professor Martin Levin seemed to demonstrate, the dynamics of sloppy, underfunded, and highly infornal criminal justice systems tend to favor defendants. ${ }^{190}$ One reason may be that even if the concept of reasonable doubt does not always mean

188. Interview with Mr. Adler in New York City (Jan. 10, 1968).

189. See text accompanying notes 94-96 supra.

190. Levin, Delay in Five Criminal Courts, 4 J. LEGAL STUD. 83 (1975). 
what it should in these systems, it nevertheless means something; when legal procedures fail to convey adequate assurance of guilt, administrators may resolve their doubts in favor of defendants in sentencing. Or it may be that a casual attitude toward procedure leads ultimately to a casual attitude toward substance; crime simply nay not seem as serious when legal procedures are not designed to treat it in a serious way. Or the reason may be soinething inore inundane-perhaps the socioeconomic backgrounds and outlooks of judges and prosecutors in systens that sometimes have been staffed by oldstyle political inachines. In any event, these informal systeins apparently yield substantially more lemient sentences than more adequately funded "good government" systems; and if a prohibition of plea bargaining were accompanied by a substantial influx of resources and a renewed commitment to treat criminal cases seriously, perhaps an overall increase in sentence severity could be anticipated. As I have indicated, I would be willing to pay this price (if price it is) and then to address questions of leniency and severity "on the inerits" in legislative and judicial forums. If our criminal justice systein is to begin to accomplish its goals, ny own view is that both "hard-liners" and "soft-liners" must abandon attachinents to irrationality that are grounded only on the perception that particular irrationalities favor their side.

If I seein an insufferable purist, however, there is another alternative. Unusually low gnilty plea rates im some cities, notably Philadelphia and Pittsburgh and apparently Baltimore as well, are explained, not by any special commitment of resources to their criminal justice systems, but simply by the frequent use of informal and expeditious bench trial procedures. ${ }^{191} \mathrm{I}$ have suggested elsewhere that these procedures, although far from perfect, represent a more sensible allocation of limited resources than the allocation aceomphished in other cities through plea bargaining. A defendant in Philadelphia or Pittsburgh is indeed pressed to waive the right to jury trial, but not to waive the right to any trial whatever. He is able to present his side of the story to an impartial third party, and le does not surrender his chance for acquittal. ${ }^{192}$ Moreover, as one who las observed the workings of criminal justice in Philadelphia and Pittsburgh and interviewed lawyers and judges who know these cities' practices, my impression-confirmed in substantial part by Professor Levim's figures ${ }^{193}$-is that the lesser reliance on plea bargaining that characterizes these jurisdictions has not led to the imposition of more severe sentences than are imposed in other places. To the contrary, the casual, overburdened judicial systems of both cities have yielded the expected result-sentences

191. See J. Eisenstein \& H. Jacob, Felony Justice: An Organizational Analysis of CrIminal Courts 67-97 (1977) (Baltimore); President's CoMmission on LAw ENForcement AND ADMINISTRATION OF JUSTICE, supra note 37, app. B, at 127 (Baltimore); Alschuler, supra note 59, at 61 \& n.36 (Philadelphia and Pittsburgh); Levin, supra note 190, at 112, Table 8, 119 \& n.72 (Pittsburgh); McIntyre \& Lippman, Prosecutors and Early Disposition of Felony Cases, 56 A.B.A. J. 1154, 1156 (1970) (Baltimore).

192. Alschuler, Book Review, supra note 174, at 1035.

193. Levin, supra note 190, at 88 , Table 1 (in Pittsburgh, $49 \%$ of all convicted felony defendants were placed on probation; in the three other felony courts studied-each characterized by a substantially higher guilty plea rate, see id. at 112, Table 8-the percentages of convicted defendants placed on probation were 32,24 , and 37 ). 
more lenient than the norm. In short, there may be some correlation between formality and severity and between expenditure levels and severity, but there is no inherent correlation between the extent of a system's rehance on plea bargaining and the sentences that it imposes. If one favors defendants as an undifferentiated group and cares only about "bottom-line" sentencing outcomes, one probably ought to prefer sloppy justice-the sloppier, in fact, the better. Even then, one need not endorse the particnlar form of casual justice known as plea bargaining.

Recent evidence suggesting that a prohibition of plea bargaiming might produce more severe sentences was presented, however, in a study by Michael L. Rubinstem, Stevens H. Clarke, and Teresa J. White for the Alaska Judicial Council. ${ }^{194}$ This study concluded that the prohibition of plea bargaining by Alaska's Attorney General had not led to imcreases im sentence severity for most crimes, but it also reported, "[W]e did find a 117 per cent increase im average sentence lengths for charges involving bad checks, forgeries, frauds and embezzlements. There was also a very large ( 233 per cent) increase in the length of drug sentences." "195 The remainder of this Appendix will be devoted to an evaluation of these findings.

In assessing the Judicial Council's conclusions, some paradoxes should be noted. First, im neither of the offense categories im which great increases in sentence severity seemed to occur was there any imcrease in the chance that a defendant would be convicted and sentenced to a term of thirty days or more. ${ }^{196}$ What the Judicial Council concluded with regard to drug offenses may have been applicable to the other offense category as well: "In other words, imcreases in postarrest screening and shifts in court disposition patterns counterbalanced the imcrease in sentence severity ...."197 Apparently Alaska's prohibition of plea bargaining did not produce greater severity for defendants as a group even in the Judicial Council's view. Convicted defendants received more severe sentences, but more intense prosecutorial screening and other developments apparently led to an offsetting decline in the number of defendants who were convicted. This finding may tend to support this Article's suggestion that "[a] restriction of plea bargaining would encourage prosecutorial decision-making 'on the merits,' and although this kind of decision-making does not always work to the benefit of defendants, sometimes it does." 198

Second and more striking, average sentence lengths in the two offense categories were not notably affected by the plea bargaining prohibition. In-

194. M. Rubinstein, S. Clarke \& T. White, supra note 83.

195. Id. at 94-95. As this Appendix will indicate, the statement quoted in text is not an accurate description of the Judicial Council's findings. Far from finding "a 117 percent increase in average sentence lengths for charges involving bad checks, forgeries, frauds and einbezzlements," the Council found a decrease in the average sentence length for this class of offenses. See text accompanying notes 198-201 infra. Nevertheless, the authors' maccurate statement of their findings has been perpetuated by a number of newspaper and magazine stories concerning the Alaska plea bargaining prohibition. It provides an appropriate starting point for analysis.

196. Id. at 125.

197. Id. at 207.

198. See text accoinpanying notes $94-95$ supra. 
deed, in two of the three cities studied, Anchorage and Juneau, these average sentence lengths declined slightly for both offense groups. In the third city, Fairbanks, there was a substantial increase in the average length of drug sentences but a substantial decrease in the severity of the sentences imposed for the relatively minor property crimes. ${ }^{199}$ Of course, to the extent that the reported statewide increase in drug sentences resulted from the distinctive practices of only one of the major cities subject to the plea bargaining prohibition, it seems unlikely that the prohibition itself accounted for this change. ${ }^{200}$ More importantly, one wonders how supposedly drainatic increases in sentence severity in two offense categories can be reconciled with the finding that mean sentence length did not increase in one of these categories and increased in only one city for the other.

The answer apparently lies in the fact that the very large perceived increases in sentence severity were simply the product of the Judicial Council's regression analyses. ${ }^{201}$ These analyses were designed to control for variables other than the impleinentation of the plea bargaining prohibition. Of course even if mean sentence lengths in the two offense categories remained constant, it would be reasonable to infer an increase im sentence severity if the cases that arose following the plea bargaining prohibition inerited less severe sentences. Equal sentences for less serious crimes might indeed reflect inore punitive attitudes toward sentencing, and the Judicial Council's use of regression analyses therefore seemed appropriate.

Nevertheless, there is little reason to believe that cases in these two offense categories did become less serious following the plea bargaining prohibition. To the contrary, prosecutors responded to the plea bargaining prohibition by intensifying their efforts to screen less serious cases from the system at the outset. The screening rate in drug cases increased by about seventy percent, ${ }^{202}$ and the Judicial Council concluded that the prosecutors' intensified screening did not reflect evidentiary weaknesses in the cases that they declined so nuch as it reflected these cases' trivial character. ${ }^{203}$ With relatively minor cases eliminated from the system, one would expect an increase in inean sentence length-an increase that would reflect the relatively aggravated character of the cases that remained rather than pumitive sentencing. This overall increase

199. M. Rubinstein, S. Clarke \& T. White, supra note 83, at 189, 294.

200. As a result of pipeline construction, moreover, Fairbanks was very much a frontier-style boom town during the relevant period. The city's policy toward drug offenses was far from constant at this time.

201. Although this important fact is revealed in the final Judicial Council report, a misleading prior article by two authors of the report simply declared that "drug felony sentences went up 233 percent" and that "defendants convicted of check, fraud and related white-collar offenses received sentences 117 percent longer." Rubinstein \& White, Alaska's Ban on Plea Bargaining, in W. McDonald \& J. Cramer, Plea-Bargaining 25, 48 (1980). These statements would naturally lead readers to conclude incorrectly that mean sentences had imcreased dramatically. The statements may be attributable to the fact that the two authors themselves misunderstood the import of the statistical material that the third author of the Judicial Council study had prepared. See, e.g., the misstatement discussed at note 195 supra - a misstatement that appeared in a portion of the final report that one of these two authors prepared.

202. M. Rubinstein, S. Clarke \& T. White, supra note 83, at 140.

203. See id. at $117,146$. 
did not materialize, however-a fact that makes the findings that emerged from the Judicial Council's regression analyses somewhat baffling. The piees of the puzzle-equally serious or more serious cases, unchanged mean sentences and supposedly dramatic mcreases in sentence severity-do not fit together.

The increases in sentence severity in drug cases and cases of relatively minor property crime were not the only dramatic findings that the regression analyses produced. For example, the Judicial Council not only reported that when a relatively minor property case arose following the plea bargaining prohibition, the sentence was likely to be $117 \%$ harsher than when the case arose prior to the ban; it also reported that when a defendant in the same crime category was represented by an appointed attorncy, his sentence was likely to be $683 \%$ more severe than when he was represented by privately retained counsel. ${ }^{204}$ It bears reiteration that this finding was the product of a statistical technique designed to minimize the impact of other possibly relevant variables.

The type of defense counsel did not significantly affect sentence length in most other crime categories, however, and for what it may be worth, my impression of the Alaska State Public Defender System is highly favorable-at least as favorable as iny impression of most of the state's private criminal defense bar. Despite the Judicial Council's "hard" data, I do not beheve that the representation provided by the Alaska State Public Defender System is so defective that it alone is likely to increase a defendant's sentence seven-fold im a fraud, bad check, forgery, or einbezzlement case. Similarly, although I do not doubt that racial bigotry may infect the administration of criminal justice in Alaska, it is somewhat difficult to beheve that black defendants in bad check cases and the like are regularly sentenced $452 \%$ more severely than comparable white defendants. ${ }^{205}$ of course, the reported $117 \%$ increase in sentence severity following the plea bargaining prohibition stands on no stronger footing than these other findings.

The massive reported increases in sentence severity that were produced by a number of variables may cause one to wonder about the baseline from which these mcreases were ineasured. This consideration could have both methodological and policy significance. On the inethodological issue, consider an extreme example. Imagine that in the year before the plea bargaining prohibition ninety-nine defendants were sentenced to probation and one defendant to a one-month term, and suppose that in the year following the prohibition ninety-nine defendants were sentenced to probation and one to a two-month term. If the probated sentences were weighed as zero (as they were in the Judicial Council's study) and if the character of the cases thcmselves did not change, the result would be a $100 \%$ increase in sentence severity (from an average of .01 months to an average of .02 months). Nevcrtheless, the change in sentencing practices would have been trivial.

On the more basic policy question, one's initial reaction to the Judicial

204. Id. at 299.

205. Id. 
Council's findings might be that Alaska's plea bargaining prohibition had produced an anomalous result-a substantial increase in sentences for relatively minor offenders but no increase for the violent criminals who ought to be the system's principal concern. This impression might be altered, however, if the sentences for minor offenders remained small and indeed seemed appropriate or perhaps even lenient after the increase. In that event, the increase might merely confirm the judginent of a prosecutor who observed that prior to the plea bargaining ban "the police complained that we were giving cases away and they were right."206 It therefore seems noteworthy that even after the plea bargaming prohibition only $16.7 \%$ of all drug cases and only $14.3 \%$ of all fraud, forgery, bad check, and embezzlenient cases resulted in sentences of thirty days or more. ${ }^{207}$

Finally, if the Judicial Council's findings were accepted at face value, they still might not indicate that plea bargaining customarily leads to inore lenient sentences than would be imposed in its absence. Avrum Gross, the Attorney General of Alaska, observed, "I'm inclined to believe that if we hadn't done a thing in terms of plea bargaming, sentencing would still be higher today. I think the sentences are a reflection of the teinper of the times."208 The Judicial Council itself noted that one reason for the apparent increase might have been "a new and more punitive attitude toward drug offenses and offenders, which may or may not have had anything to do witl the new policy against plea bargaining."209

Indeed, in some of its statistical analyses, the Judicial Council not only compared case outcomes during the year before the plea bargaining prohibition and the year after; it also subdivided each year into six-month periods so that it could determine whether apparent changes had begun before the prohibition, at the time of the prohibition, or later. The Council reported, for exan1ple, that "over the four time periods there was a slight but continual increase in the proportion of cases resulting in conviction and . . . imprisonment of 30 days or more: $16.8,17.7,18.5$, and 19.3."210 This finding n1ay suggest that more punitive attitudes had indeed begun to emerge prior to the plea bargaining ban and that the ban itself did not accentuate this trend.

With regard to drug offenses and ininor property offenses, the patteru was simply capricious. The highest proportion of drug cases leading to sentences of thirty days or more arose in the six-month period immediately following the plea bargaining prohibition, but the next six-month period saw the lowest proportion. With the relatively ininor property offenses, by contrast, the sixmonth period immediately after the prohibition saw the lowest proportion of cases resulting in sentences of thirty days or more while the following sixmonth period saw the highest. ${ }^{211}$ It therefore seems unfortunate that in

206. Interview with James Gould, Assistant District Attorney, in Anchorage, Alaska (June 10, 1976).

207. M. Rubinstein, S. Clarke \& T. White, supra note 83, at 292.

208. Id. at 13 .

209. Id. at 206.

210. Id. at 179 .

211. Id. at 292 . 
describing the apparent increases in sentence severity in drug and minor property cases, the Judicial Council simply coinpared the year before and the year after the plea bargaining prohibition; it did not examine the four six-1nonth periods separately.

The Council did offer at least one plausible reason for concluding that Alaska's prohibition of plea bargaiming might have led to enhanced sentences in drug cases: "Alaskan judges acting alone in Year Two [1nay have] had more punitive attitudes toward drug offenses than did prosecution-defense negotiating groups in Year One. Perhaps this can be attributed to judges as a group being older than prosecutors, and consequently less accepting of drug use."212 If this explanation is credited, it suggests that attitudes toward drug offenses were changing and that there was a generation gap in Alaska as elsewhere. It does not suggest, however, that plea bargaining as an institution is more likely to lead to inore lenicnt treatinent than judicial sentencing. If, for example, inenibers of the older generation had been negotiating while members of the younger generation had been on the bench, the result of the Judicial Council's inquiry might well have been reversed. The question whether sentencing in drug cases should be entrusted to older people with greater legal experience or to younger people more likely to have used drugs themselves is distinct from the question whether plea bargaining is desirable.

I do not mean to deprecate the generally well-conceived, capably executed, and clearly presented statistical analyses that the Judicial Council performed. Nevertheless, for all of the reasons discussed in this Appendix, I doubt that the Alaska experience provides strong support for the view that a prohibition of plea bargaining would be likely to produce more severe sentences.

In commenting on a draft of this Appendix, Professor Stevens H. Clarke, one of the authors of the Judicial Council study, noted that increases in sentence severity in drug cases and cases of relatively minor property crime were indicated, not only by the Council's regression analyses, but also by an independent multivariate analysis. Nevertheless, this analysis employed the sanie variables as the regression analyses, and unlike the inore dramatic regressions, it did not attempt to neasure the magnitude of the sentencing increases. It certainly did not suggest that these increases were very great. Moreover, in drug cases, the evidence that the plea bargaming prohibition had led to more severe sentences was not statistically significant under the standards that social scientists usually employ; there was a twelve percent possibility that the perceived correlation could have arisen merely by chance. ${ }^{213}$

212. Id. at 228.

213. See id at 301-02. 